Editora Poisson

Organizadora

\section{Educação Física e Ciências Esportivas Volume 1}

1a Edição

Belo Horizonte

Poisson

2021 
Editor Chefe: Dr. Darly Fernando Andrade

\section{Conselho Editorial}

Dr. Antônio Artur de Souza - Universidade Federal de Minas Gerais

Ms. Davilson Eduardo Andrade

Dra. Elizângela de Jesus Oliveira - Universidade Federal do Amazonas

Msc. Fabiane dos Santos

Dr. José Eduardo Ferreira Lopes - Universidade Federal de Uberlândia

Dr. Otaviano Francisco Neves - Pontifícia Universidade Católica de Minas Gerais

Dr. Luiz Cláudio de Lima - Universidade FUMEC

Dr. Nelson Ferreira Filho - Faculdades Kennedy

Ms. Valdiney Alves de Oliveira - Universidade Federal de Uberlândia

Dados Internacionais de Catalogação na Publicação (CIP)
E24 Educação Física e Ciências Esportivas -
Volume 1/ Organização Editora Poisson -
Belo Horizonte - MG: Poisson, 2021
Formato: PDF
ISBN: 978-65-5866-117-7
DOI: 10.36229/978-65-5866-117-7
Modo de acesso: World Wide Web
Inclui bibliografia
1. Educação Fisica 2. Esportes.I. Título.
Sônia Márcia Soares de Moura - CRB 6/1896

O conteúdo deste livro está licenciado sob a Licença de Atribuição Creative Commons 4.0.

Com ela é permitido compartilhar o livro, devendo ser dado o devido crédito, não podendo ser utilizado para fins comerciais e nem ser alterada.

O conteúdo dos artigos e seus dados em sua forma, correção e confiabilidade são de responsabilidade exclusiva dos seus respectivos autores.

www.poisson.com.br

contato@poisson.com.br 


\section{SUMÁRIO}

Capítulo 1: Capacidades físicas e funções táticas no futsal. 06

Samuel Panato, Paulo Henrique Pauli, Mayara Maciel Batista, Marcus Peikriszwili Tartaruga

DOI: 10.36229/978-65-5866-117-7.CAP.01

Capítulo 2: Efeitos da liberação miofascial na flexibilidade de mulheres adultas, praticantes de ginástica localizada no SESC Campinas.

Daiane Almeida Rodrigues, Johnathan Pereira de Castro

DOI: 10.36229/978-65-5866-117-7.CAP.02

Capítulo 3: A corporeidade Freireana.

Rafael Vieira de Araújo, Teresa Cristina Barbo Siqueira, Rildo Vieira de Araújo

DOI: $10.36229 / 978-65-5866-117-7 . C A P .03$

Capítulo 4: 0 circo adaptado como ferramenta de desenvolvimento integral para pessoas com deficiência 26

Carina Lopes Moreira, Tatiana Robles Santiago, Aline Aparecida Ribeiro, Larissa Henrique Ferrari, Nathaly Freitas de Souza

DOI: $10.36229 / 978-65-5866-117-7 . C A P .04$

Capítulo 5: Possibilidades e limites dos alunos com deficiência nas aulas de educação física: Um relato de experiência 30

Antonio Jansen Fernandes da Silva, Alex de Freitas Pinto, Bryan Kenneth Marques Pereira, Patrícia Mozart Moura, Maria Aparecida Dias

DOI: 10.36229/978-65-5866-117-7.CAP.05

Capítulo 6: Concepção dos bolsistas sobre um projeto de ensino em Educação Física com o público alvo da Educação Especial

Solange Rodovalho Lima, Juliana Cristina Silva, Leandro Rezende

DOI: 10.36229/978-65-5866-117-7.CAP.06

Capítulo 7: Educação Física e Atendimento Educacional Especializado: Ampliando possibilidades na EJA

Marcela Fontão Nogueira, Adriana Della Gatta Soares

DOI: $10.36229 / 978-65-5866-117-7 . C A P .07$ 


\section{SUMÁRIO}

Capítulo 8: A atuação do professor de Educação Física na Atenção Básica de Saúde 47

Daniel Castilho de Souza, Jamila Mariana Martins da Cruz, Layse de Oliveira Monteiro, Paula Carolina Silva Santos, Pedro Vitor Nascimento de Paiva, Simone de La Rocque Cardoso

DOI: $10.36229 / 978-65-5866-117-7 . C A P .08$

Capítulo 9: 0 esporte e o lazer no processo de formação integral dos educandos em uma escola federal em Rio Branco/Acre 49

Alessandra Lima Peres de Oliveira, Kelly Cebelia das Chagas do Amaral, Denise Jovê Cesar, Eroína Moreira de Melo

DOI: $10.36229 / 978-65-5866-117-7 . C A P .09$

Capítulo 10: Ações educacionais no âmbito da educação física escolar: Desafios e possibilidades em curso

Alysson Carlos Ribeiro Gomes, Jefferson Francisco Cândido, Tatiane Meire Martins

DOI: $10.36229 / 978-65-5866-117-7 . C A P .10$

Capítulo 11: Alunos “Em Cena”: Pesquisa pedagógica com mídias tecnológicas na Educação Física escolar.

Renata de Oliveira Carvalho, Andressa Ceni Lopes, Lediana Ribeiro de Quadros, Liziane Nichele Pereira, Paulo Gomes Sousa-Filho

DOI: $10.36229 / 978-65-5866-117-7 . C A P .11$

Capítulo 12: Uma proposta para integrar o ensino da Física com Educação Física no Ensino Médio. 63

Fernando Lima Torreiro, Eleneide Menezes Alves, Romildo de Albuquerque Nogueira

DOI: $10.36229 / 978-65-5866-117-7 . C A P .12$

Autores: 


\section{Capítulo 1}

\section{Capacidades físicas e funções táticas no futsal}

\section{Samuel Panato}

\section{Paulo Henrique Pauli}

Mayara Maciel Batista

Marcus Peikriszwili Tartaruga

Resumo: 0 presente estudo teve como objetivo investigar as capacidades físicas decorrentes das funções táticas de futebolistas de salão (Futsal). Trinta e três atletas masculinos, divididos igualitariamente em três grupos (pivôs, fixos e alas), foram submetidos a um protocolo de contração voluntária máxima isométrica (CVMI) em cadeira extensora objetivando a determinação da máxima produção de força muscular de quadríceps do membro inferior dominante, a dois testes neuromusculares velocidade (20-m) e agilidade (Illinois) - e a três saltos em Counter Movement Jump (CMJ) visando a determinação da máxima altura vertical. Os principais achados demonstram que os pivôs, com maiores estaturas $(1,78 ; 1,74$ e $1,72 \mathrm{~m})$ e massas corporais $(78,2 ; 73,5$ e 64,3 kg), tendem a ser mais fortes (688,1; 635,5 e 568,3 N) e potentes (593,2; 468,5 e 292,3 W) que fixos e alas, respectivamente. Porém, não foram verificadas diferenças significativas intergrupos $(p>0,05)$ nos parâmetros de velocidade $(3,2 ; 3,09$ e 3,0 s) e agilidade (15,75; 15,42 e 15,18 s). 0 presente estudo permite concluir que as exigências específicas dos movimentos desempenhados nas funções táticas do Futsal, associado ao treinamento físico, podem influenciar nas capacidades físicas de atletas masculinos.

Palavras-Chave: Avaliação física, desempenho, esporte coletivo. 


\section{INTRODUÇÃO}

O Futebol de Salão (Futsal) é caracterizado como um esporte intermitente onde ocorrem ações de grande intensidade, intercaladas por breves períodos de recuperação. Análises das demandas de jogo demonstram que praticantes de elite dispendem um tempo considerável de jogo em ações de altas intensidades, tais como os sprints - acima de 85\% da frequência cardíaca máxima (SILVA e col., 2012), sendo estas responsáveis por momentos decisivos de uma partida (BARBERO-ÁLVAREZ e col., 2008). Associado ao fato de se tratar de uma modalidade esportiva realizada em espaços-físicos de pequenas dimensões, parâmetros neuromusculares, tais como a potência e a força muscular de membros inferiores, bem como a agilidade e velocidade de deslocamento, são importantes capacidades físicas para um bom desempenho esportivo em cada uma das funções táticas (MOHR e col., 2003).

O Futsal é composto por diferentes funções táticas, tais como o ala, o fixo e o pivô, além do goleiro. 0 ala é o responsável pelo desenvolvimento das jogadas, devendo deslocar-se constantemente, com ou sem a posse da bola, movimentando-se em posições invertidas referente a perna dominante. 0 fixo tem como principal função a armação da jogada, além de necessitar de um bom passe e de uma excelente habilidade. Por fim, o pivô permanece mais tempo de costas para o gol, sendo responsável em proporcionar uma maior movimentação à equipe (QUEIROGA e col., 2005).

Estudos recentes têm destacado a importância da velocidade de deslocamento e da agilidade como componentes primordiais para um bom desempenho no Futsal. Reilly e Thomas (1976) verificaram que um deslocamento em alta velocidade ocorre, em média, cada $90 \mathrm{~s}$, com durações entre 2 e $4 \mathrm{~s}$, constituindo-se em, aproximadamente, $11 \%$ da distância total percorrida na partida e em 3\% do tempo total de jogo (SPENCER e col., 2005). De acordo com Silva e col. (2012), isso sugere que o desempenho em exercícios de elevada intensidade é dependente do nível de potência muscular, ou seja, da capacidade de recrutamento neural, do aproveitamento do ciclo alongamento-encurtamento (CAE) e da taxa de liberação de energia por meio da via metabólica anaeróbica.

Porém, os parâmetros neuromusculares podem apresentar diferenças entre atletas que atuam em diferentes funções táticas, conforme verificado por Wisloff e col. (1998). Além disso, atletas de diferentes funções táticas também podem apresentar níveis de potência muscular diferenciados, tendo em vista que o potencial elástico do músculo esquelético é uma propriedade que pode ser melhorada através dos anos de treinamento (DI SALVO e col., 2007).

A necessidade de se analisar separadamente as características antropométricas de atletas de acordo com função tática desempenhada na equipe é evidente, pois observa-se que a estrutura corporal segue tendência de homogeneização em grupos específicos de atletas competitivos, em relação a um perfil que se acredita como adequado ou indicado para uma determinada atividade (SHARMA e DIXIT, 1985). A importância em se determinar o perfil físico de esportistas reside no fato da existência de uma relação entre forma corporal e desempenho físico (SLAUGHTER e col., 1977). De fato, diversos estudos têm procurado estabelecer as características somatotipológicas de atletas das mais variadas atividades esportivas ou associá-las ao desempenho obtido na competição. No caso específico do Futsal, características antropométricas podem ser relevantes para uma melhor compreensão das capacidades físicas, tais como a velocidade de deslocamento, agilidade, força e potência muscular, todas bastante presentes nas ações motoras desempenhadas durante uma partida (QUEIROGA e col., 2005).

Apesar da importância das capacidades físicas e antropométricas para uma boa execução das funções táticas no Futsal, uma melhor compreensão destes parâmetros torna-se necessária objetivando-se o melhor rendimento esportivo (SILVA e col., 2012). Sabe-se, por exemplo, que atletas com baixos percentuais de gordura tendem a apresentar melhores resultados em testes de força e potência neuromusculares, contrariamente aos resultados em testes cardiorrespiratórios (GOROSTIAGA e col., 2009). Contudo, as magnitudes de diversos parâmetros neuromusculares nas funções táticas do Futsal têm sido pouco investigadas. Desta maneira, o presente estudo teve como objetivo investigar as capacidades físicas decorrentes das funções táticas de atletas de Futsal.

\section{METODOLOGIA}

A amostra, selecionada por voluntariedade, foi constituída por trinta e três jogadores profissionais de Futsal distribuídos em três grupos: alas, fixos e pivôs. Todos compareceram ao Laboratório de Biomecânica e Energética do Movimento Humano (MEMH), da Universidade Estadual do Centro-Oeste (UNICENTRO), para as realizações dos procedimentos de caracterização da amostra e coletas de dados. 0 número amostral mínimo necessário para a realização do presente estudo $(\mathrm{n}=33)$ foi determinado a 
partir de De-Oliveira e col. (2006) e Silva e col. (2012) adotando-se o programa Computer Programs for Epidemiologic Analyses (PEPI), com nível de significância de 0,05 e poder de $80 \%$.

Profissionais com experiência de, no mínimo, dois anos em competições regionais e/ou nacionais, com idade entre 18 e 35 anos, foram considerados como critérios de inclusão amostral. Sujeitos com lesões osteoarticulares, e/ou que estivessem em fase de tratamento médico, não foram incluídos na amostra. 0 presente estudo foi aprovado pelo Comitê de Ética institucional ( $\left.{ }^{\circ} 2.200 .772\right)$.

\section{1 - SESSÃO - CARACTERIZAÇÃO AMOSTRAL}

Em datas e horários pré-estabelecidos os sujeitos preencheram e assinaram o Termo de Consentimento Livre e Esclarecido (TCLE) e uma ficha de dados pessoais, sendo as medidas antropométricas mensuradas em uma balança e um estadiômetro (Filizola, São Paulo, Brasil), com resoluções de $100 \mathrm{~g}$ e $1 \mathrm{~mm}$, respectivamente, e capacidade de $150 \mathrm{~kg}$.

\section{2a SESSÃO - TESTES NEUROMUSCULARES}

Para a mensuração da velocidade máxima de deslocamento e da agilidade, os sujeitos foram submetidos aos testes de velocidade máxima de 20 m e Illinois, com o auxílio de uma fotocélula SPEED TEST 6.0 (Cefise, São Paulo, Brasil). A força de membros inferiores foi mensurada de maneira direta através de uma célula de carga (Cefise, São Paulo, Brasil) acoplada a uma cadeira extensora. Os sujeitos foram posicionados junto a mesma onde exerceram três contrações voluntárias máximas isométricas (CVMI) do membro inferior dominante, com o joelho e o quadril posicionados a 90 graus, respeitando-se os intervalos de 3 min para cada medida. 0 maior valor foi considerado para fins de tratamento de dados. Para a determinação da potência dos membros inferiores e a altura máxima no salto vertical adotou-se o tapete Multisprint (Hidrofit, Belo Horizonte/MG, Brasil) onde os sujeitos foram instruídos a realizarem três saltos máximos verticais em Counter Movement Jump (CMJ).

\section{PROCEDIMENTOS ESTATÍSTICOS}

Foram realizados os testes de Shapiro-Wilk e a Análise de Variância (ANOVA) de medidas repetidas, com post hoc de Bonferroni. 0 nível de significância adotado em todos os testes foi de 0,05, utilizando-se o pacote estatístico Statistical for Social Sciences Software - SPSS, versão 20.0.

\section{RESULTADOS}

Diferenças estatisticamente significativas foram verificadas nas variáveis massa corporal e estatura dos pivôs e fixos em comparação aos alas (ver tabela 1). Também foram verificadas diferenças estatisticamente significativas entre os grupos nos parâmetros de força e potência máxima (ver tabela 2). Porém, apesar da tendência de alas serem mais velozes e ágeis que fixos e pivôs, respectivamente, não foram verificadas diferenças estatisticamente significativas nessas capacidades neuromusculares (ver tabela 3).

Tabela 1 - Médias e DP da caracterização amostral de atletas masculinos de Futebol de Salão.

\begin{tabular}{|l|c|c|c|c|c|c|}
\hline \multicolumn{2}{|c}{ ALAS $(n=11)$} & \multicolumn{2}{c|}{ FIXOS $(n=11)$} & \multicolumn{3}{c|}{ PIVÔS $(n=11)$} \\
\hline Idade (anos) & 21 & $\pm 2,7$ & 22 & $\pm 4,4$ & 22 & $\pm 5,4$ \\
\hline Massa Corporal $(\mathrm{kg})$ & 64,3 & $\pm 7,7$ & $73,5^{*}$ & $\pm 8,1$ & $78,2^{*}$ & $\pm 8,6$ \\
\hline Estatura (m) & 1,72 & $\pm 0,05$ & $1,74^{*}$ & $\pm 0,05$ & $1,78^{*}$ & $\pm 0,04$ \\
\hline
\end{tabular}

\footnotetext{
Nota: Diferenças estatisticamente significativas $(\mathrm{p} \leq 0,05)$ em comparação ao grupo alas $\left(^{*}\right)$.
} 
Tabela 2 - Médias e DP de respostas neuromusculares de atletas masculinos de Futsal.

\begin{tabular}{|l|c|c|c|c|c|c|}
\hline \multicolumn{2}{|c|}{ ALAS $(n=11)$} & \multicolumn{2}{c|}{ FIXOS $(n=11)$} & \multicolumn{2}{c|}{ PIVÔS $(n=11)$} \\
\hline Força Máxima (N) & 568,3 & $\pm 16,1$ & $635,5^{\mathrm{a}}$ & $\pm 22,1$ & $688,1^{\mathrm{a}, \mathrm{b}}$ & $\pm 44,6$ \\
\hline Potência Máxima (W) & 292,3 & $\pm 12,9$ & $468,5^{\mathrm{a}}$ & $\pm 47,8$ & $593,2^{\mathrm{a}, \mathrm{b}}$ & $\pm 64,3$ \\
\hline Altura CMJ (m) & 0,31 & $\pm 0,06$ & 0,31 & $\pm 0,04$ & 0,29 & $\pm 0,05$ \\
\hline
\end{tabular}

Nota: Diferenças estatisticamente significativas $(\mathrm{p} \leq 0,05)$ para alas $(\mathrm{a})$ e fixos $(\mathrm{b})$.

Tabela 3 - Médias e DP de testes neuromusculares de atletas masculinos de Futsal.

\begin{tabular}{|l|l|l|l|l|l|l|}
\hline \multicolumn{2}{|c}{ ALAS $(n=11)$} & PIXOS $(n=11)$ & PIV $(n=11)$ \\
\hline Teste de 20m (s) & 3,00 & $\pm 0,15$ & 3,09 & $\pm 0,16$ & 3,20 & $\pm 0,30$ \\
\hline Teste de Illinois (s) & 15,18 & $\pm 0,72$ & 15,42 & $\pm 0,56$ & 15,75 & $\pm 0,69$ \\
\hline
\end{tabular}

\section{DISCUSSÃO}

O presente estudo teve como objetivo investigar as capacidades físicas decorrentes das funções táticas de atletas de Futsal. Os principais achados demonstram que os pivôs, com maiores estaturas e massas corporais, tendem a ser mais fortes e potentes que fixos e alas, respectivamente; apesar de não haverem existido diferenças estatisticamente significativas nas capacidades neuromusculares avaliadas.

De acordo com Avelar e col. (2008), os alas são responsáveis pela armação das jogadas, deslocando-se constantemente, com ou sem bola. Além disso, tendem a apresentar massas corporais e estaturas médias inferiores a fixos e pivôs, corroborando com as tendências verificadas no nosso estudo. Segundo Cyrino e col. (2002), o aperfeiçoamento da função tática advindo do treinamento pode provocar importantes modificações nos parâmetros corporais, principalmente na massa corporal e, consequentemente, no desempenho esportivo. De fato, diversos estudos têm demonstrado que, dentre as variáveis que podem ser avaliadas antropometricamente, as mais relevantes para o desempenho atlético na maioria dos esportes são a estatura e a composição corporal (BAILEY e col., 1986). Apesar das poucas informações disponíveis na literatura, os menores valores de gordura corporal e/ou maiores quantidades de massa muscular, podem favorecer o rendimento máximo, visto que a movimentação durante as partidas é extremamente intensa, com alta exigência energética (CYRINO e col., 2002) inclusive, também influenciando na força e potência de membros inferiores, essenciais para o desempenho no Futsal (WISLOFF e col., 1998). No nosso estudo, pivôs apresentaram maiores massas corporais assim como maiores respostas neuromusculares (força e potência máxima) em comparação aos fixos e alas, respectivamente.

Segundo Ré (2018), atletas de Futsal tendem a serem mais velozes e ágeis em comparação a atletas de outras modalidades esportivas em decorrência das especificidades motoras exigidas. Uma característica importante dos fundamentos técnicos é a relativa precisão com que os mesmos devem ser executados e a consequente dependência de uma adequada capacidade de organização e controle do movimento. Considerando que o sistema nervoso central (SNC) está diretamente relacionado com a capacidade de organização e controle do movimento (coordenação motora), é possível afirmar que o treinamento e aperfeiçoamento da técnica devem ser considerados no planejamento esportivo. Porém, no Futsal, a execução de determinada ação está diretamente ligada à necessidade do jogo. Logo, é difícil prever seu resultado sem considerar tal necessidade, fato que exige um forte envolvimento cognitivo durante a execução dos fundamentos (RÉ, 2018). De fato, a tomada de decisão em situação real de jogo não acontece de modo desvencilhado das possibilidades de ação do executante, ou seja, não basta identificar qual a melhor solução, mas sim, a solução mais adequada para as características do executante (ARAÚJO e col., 2006) - algo já reportado por Wisloff e col. (1998) ao demonstrarem diferenças significativas em respostas neuromusculares entre jogadores de Futsal que desempenham diferentes funções táticas.

Apesar de haver uma tendência de alas serem mais velozes e ágeis que fixos e pivôs, respectivamente, no presente estudo não foram verificadas diferenças estatisticamente significativas nas velocidades máximas de deslocamento e nas agilidades entre os grupos. Mesmo acreditando-se que esses resultados podem ser uma consequência metodológica relacionadas aos testes neuromusculares adotados, bem como ao número amostral considerado, alguns estudos, tais como os de Young e col. (2002) e Chaouachi e col. (2012), também não têm verificado diferenças significativas em determinadas capacidades neuromusculares, tais como a velocidade máxima de deslocamento e a agilidade, entre jogadores que desempenham diferentes funções táticas esportivas. Em contrapartida, autores com Peterson e col. (2006) e Wisloff e col. (2004) têm demonstrado fortes correlações entre capacidades e respostas neuromusculares, sendo as diferenças 
nos resultados dos estudos justificadas por questões de protocolos e ciclos de treinamentos. De fato, o treinamento neuromuscular, bastante considerado no macrociclo esportivo, também tem resultado em adaptações fisiológicas significativas, conforme demonstrado por Barazetti e col. (2008). Ao investigar a influência do treinamento de força de trinta atletas de Futsal, estes observaram aumentos da força explosiva associada ao ganho de massa muscular. Em geral, é provável que o treinamento desportivo, associado a especificidade da função tática no Futsal, justifique uma provável relação entre massa corporal, respostas e capacidades neuromusculares, algo verificado neste estudo.

\section{CONCLUSÃO}

Com base nos resultados do presente estudo verificou-se que os pivôs, com maiores estaturas e massas corporais, tendem a ser mais fortes e potentes que fixos e alas, respectivamente. Por outro lado, a ausência de diferenças entre as posições de jogo nas variáveis de desempenho neuromuscular sugere a existência de homogeneidade no desempenho físico de atletas de Futsal que executam diferentes funções táticas resultados esses que podem ser atribuídos as constantes evoluções da regra e da dinâmica da modalidade que, por sua vez, tem exigido a participação efetiva dos atletas em diferentes posições de jogo.

De uma forma geral, os resultados podem contribuir para a caracterização do perfil físico de atletas de Futsal, bem como no fornecimento de subsídios para uma melhor adequação do treinamento físico destas atletas a fim de que o desempenho possa ser otimizado dentre cada função tática.

Porém, é importante ressaltar que embora os níveis de força e potência neuromuscular, em sua maioria, tenham sido diferentes nos grupos táticos de atletas analisados, sugerem-se mais estudos que avaliem as variáveis em questão utilizando outras metodologias e instrumentos de medidas.

\section{AGRADECIMENTO}

Agradecimento especial a Fundação Araucária/PR pelo apoio prestado.

\section{REFERÊNCIAS}

[1] Araújo, D.; Davids, K.; Hristovski, R. The ecological dynamics of decision making in sport. Psychology of Sport and Exercise. 7:653-676, 2006.

[2] Avelar, A.; Dos Santos, K.M.; Cyrino, E.S.; Carvalho, F.O.; Dias, R.M.R.; Atimari, L.R.; Gobbo, L.A. Anthropometric and motor performance profile of elite futsal athletes. Brazilian Journal of Kinanthropometry and Human Performance. 10(1):76-80, 2008.

[3] Bailey, D.A.; Malina, R.M.; Mirwald, R.L. Physical activity and growth of the child. In: Falkner, F. \& Tanner, J.M. (eds.). Human growth: a comprehensive treatise. 2.ed. New York, Plenum Press, p.147-170, 1986.

[4] Barazetti, L.K.; Sanches, V.; Basso, J.; Falavigna, N. Análise das variáveis de performance após intervenção de treinamento de força específico em atletas de futsal feminino. Coleção Pesquisa em Educação Física. 7(2), 2008.

[5] Barbero-Alvarez, J.C.; Soto, V.M.; Barbero-Alvarez, V.; Granda-Vera, J. Match analysis and heart rate of futsal players during competition. Journal of Sports Sciences. 26(1):63-73, 2008.

[6] Chaouachi, A.; Manzi, V.; Chaalali, A.; Wong, D.P. Determinants Analysis of Change-of-Direction Ability in Elite Soccer Players. The Journal of Strength and Conditioning Research. 26(10):2667-2676, 2012.

[7] Cyrino, E.S.; Altimari, L.R.; Okano, A.H.; Coelho, C.F. Effects of futsal training on the body composition and motor performance of young athletes. Brazilian Journal of Science and Movement. 10:41-46, 2002.

[8] De Oliveira, R.C. The football in Physical Education classes: between 'dribbles', prejudice and inequality. Motriz. 12(3):301-306, 2006.

[9] Di Salvo, V.; Baron, R.; Tschan, H.; Calderon Montero, F.J.; Bachl, N.; Pigozzi, F. Performance characteristics according to playing position in elite soccer. International Journal of Sports Medicine. 28(3):222-227, 2007.

[10] Gorostiaga, E.M.; Llodio, I.; Ibáñez, J.; Granados, C.; Navarro, I.; Ruesta, M.; Bonnabau, H.; Izquierdo, M. Differences in physical fitness among indoor and outdoor elite male soccer players. European Journal of Applied Physiology. 106(4):483-91, 2009.

[11] Mohr, M.; Krustrup, P.; Bangsbo, J. Match performance of high-standard soccer players with special reference to development of fatigue. Journal of Sports Sciences. 21(7):519-528, 2003.

[12] Peterson, M.D.; Alvar, B.A.; Rhea, M.R. The contribution of maximal force production to explosive movement 
among young collegiate athletes. Journal of Strength and Conditioning Research. 20(4): 867-873, 2006.

[13] Queiroga, M.R.; Ferreira, S.A.; Romanzini, M. Anthropometric profile of elite athletes of women's futsal according to tactical function in the game. Brazilian Journal of Kinanthropometry and Human Performance. 7(1):30$34,2005$.

[14] Ré, A.N. Characteristics of football and soccer: judgment for the training of adolescents and young adults. EF Deportes.com. 13(127), 2008.

[15] Reilly, T.; Thomas, V. A motion analysis of work rate in different positional roles in professional football match-play. Journal of Human Movement Studies. 2(1):87-97, 1976.

[16] Sharma, S.S.; Dixit, N.K. Somatotype of athletes and their performance. International Journal of Sports Medicine. 6:161-162, 1985.

[17] Silva, J.F.; Detanico, D.; Floriano, L.T.; Dittrich, N.; Nascimento, P.C.; Santos, S.G.; Guglielmo, L.G.A. Levels of muscle power in soccer and futsal athletes of different categories and positions. Motricidade. 8(1):14-22, 2012.

[18] Slaughter, M.H.; Lohman, T.G.; Misner, J.E. Relationship of somatotype and body composition to physical performance in 7 to 12 year boys. Research Quarterly for Exercise and Sport. 48(1):159-168, 1977.

[19] Spencer, M.; Bishop, D.; Dawson, D.; Goodman, C. Physiological and metabolic responses of repeated-sprint activities: Specific to field-based team sports. Sports Medicine. 35(12):1025-1044, 2005.

[20] Wisloff, U.; Castagna, C.; Helgerud, J.; Jones, R.; Hoff, J. Strong correlation of maximal squat strength with sprint performance and vertical jump height in elite soccer players. British Journal of Sports Medicine. 38(3): 285-288, 2004.

[21] Wisloff, U.; Helgerud, J.; Hoff, J. Strength and endurance of elite soccer players. Medicine \& Science in Sports \& Exercise. 30(3):462-667, 1998.

[22] Young, W.B.; James, R.; Montgomery, I. Is muscle power related to running speed with changes of direction? Journal of Sports Medicine and Physical Fitness. 43:282-288, 2002. 


\section{Capítulo 2}

Efeitos da liberação miofascial na flexibilidade de mulheres adultas, praticantes de ginástica localizada no SESC Campinas

\section{Daiane Almeida Rodrigues \\ Johnathan Pereira de Castro}

Resumo: Este trabalho é uma busca de conhecimento e experiência na conclusão do estágio em Educação Física, na Atividade Desenvolvimento Físico-Esportivo, ocorrido nas Unidades Executivas/Operacionais do Sesc (Serviço Social do Comércio) Departamento Regional em Goiás: Sesc Cidadania (2015) e Sesc Campinas (2016) na cidade de Goiânia. 0 objetivo do presente estudo foi investigar os efeitos da Liberação Miofascial (LM) sobre a flexibilidade de mulheres adultas praticantes de ginástica localizada, analisar a efetividade desta técnica nas aulas como ferramenta metodológica para a melhoria do desempenho físico. Foi traçado perfil de grupo desejado por meio de informações coletadas no Programa de Avaliação Físico-Funcional e no Módulo de Atividades - Central de Atendimentos e pela realização do teste "Sentar-e-Alcançar" pré e pós-intervenção com a técnica de Liberação Miofascial. Fizeram parte da pesquisa 13 alunas de Ginástica Localizada do Sesc de Campinas, com idade média de 46 anos, divididas em dois grupos experimentais, ambos realizaram os mesmos testes de flexibilidade e aplicação da técnica de LM por cinco sessões. Para análise de classificação dos níveis de flexibilidade utilizou-se das Diretrizes do Colégio Americano do Esporte (ACSM) 7a edição, 2007. Os resultados indicaram mudança significativa. A técnica de LM influenciou positivamente no desempenho físico dos indivíduos.

Palavras-chave: Liberação Miofascial, Flexibilidade, Ginástica localizada. 


\section{INTRODUÇÃO}

A prática de atividades físico-esportivas, segundo o Módulo Político da Atividade Desenvolvimento FísicoEsportivo (2007) "contribui para melhoria da qualidade de vida no âmbito do bem-estar físico, psíquicas e sociais do indivíduo". Tais práticas, também afirmadas no referido documento, sendo desenvolvidas de forma regular podem potencializar epreservar as capacidades físicas, funcionais e psíquicas do indivíduo.

Neste intento da potencialização e da preservação das habilidades corporais, a flexibilidade é uma qualidade física importante a ser trabalhada ao longo da vida para o desenvolvimento das atividades de vida diárias com qualidade, minimizando risco de lesões e proporcionando ao indivíduo maior liberdade de movimentos harmônicos, além de colaborar para o aumento da autonomia, principalmente, na idade avançada, conforme apresentado por Dantas (1999).

Sharkey (1998) disse que a flexibilidade reduz com a idade e inatividade, tendo uma possibilidade de maior ocorrer lesões à medida que ocorre a diminuição da mesma. Dantas (1999) acrescenta que em indivíduos sedentários este aspecto influência nas tarefas do cotidiano, como subir escadas, entrar em baixo do carro, pegar objetos no alto e nas demais ações físicas "caseiras" e laborais.

Acredita-se que a o método de Liberação Miofascial atua com eficiência no trabalho de ganho dessa flexibilidade independente de ser aplicada pré ou pós-prática e/ou treino físico- esportivo. Método este pode ser realizado via aplicação de pressão em alguns pontos do corpo, nos chamados de pontos-gatilhos, termo utilizado por Simons e Travell no ano de 1999, regiões mais firmes nos músculos e dolorosas à palpação, podendo ir desde apenas uma sensação de dor local a uma dor distante da fonte, também conhecida como dor irradiada. Esta liberação é uma técnica que atua com mobilizações manuais da fáscia, que são executadas para aumentar a amplitude de movimento, aliviar a dor e restaurar a quantidade e a qualidade normal dos movimentos.

A partir desta percepção, presumisse que o método de Liberação Miofascial (LM) pode contribuir na melhora da flexibilidade e possuir grande relevância quando empregada em programas de treinamentos físico-esportivos. Assim, deu-se início ao seguinte questionamento: Quais efeitos gerados pela Liberação Miofascial na flexibilidade corporal de mulheres adultas praticantes de Ginástica Localizada?

Cabe destacar que o interesse inicial por este tema foi derivado das vivências desenvolvidas no campo de estágio com a turma de Alongamento composta por alunos do ensino médio do Centro Educacional Sesc Cidadania (CENESC). E, após capacitação em cursos extracurriculares da Primorato e core $360^{\circ}$ com o conteúdo a técnica liberação miofascial, a curiosidade inicial tomou corpo de uma prévia produção científica, que agora está praticamente findada, ao final do período de estágio, já no Sesc Campinas e da pretendida conclusão da graduação no curso de Educação Física.

Este trabalho somou as vivências no campo de estágio com as capacitações específicas e a procura por responder a problemática quanto a influência da Liberação Miofascial sobre a flexibilidade/amplitude do movimento da articulação das regiões: coxo-femoral, com participação da musculatura quadrado lombar da coluna lombar, isquiotibiais e gastrocnêmicos. Assim como, a compreensão do cenário da mulher moderna quanto as práticas físico-esportivas, obrigações sociais, familiares e laborais. Também, a aplicabilidade desta técnica como uma possível ferramenta para a melhoria dessa qualidade física quando empregada nas aulas de ginástica localizada. Também, buscou-se avaliar a existência de diferenças e dos benefícios significativos quanto a aplicação da Liberação Miofascial utilizando o movimento de deslizamento profundo nas aulas de Ginástica Localizada na Unidade Sesc Campinas - DR/GO. Ao longo texto serão apresentados os dados coletados via aplicação do teste "sentar e alcançar" e o levantamento de perfil das alunas praticantes de ginástica localizada. A discussão foi pautada no confronto dos dados coletados e referenciais que buscaram responder ao problema, apresentando os efeitos, as aplicabilidades e potencialidades da técnica de Liberação Miofascial quando utilizadas nas aulas de ginástica localizada.

\subsection{JUSTIFICATIVA}

A Unidade Sesc Campinas é um celeiro de recursos materiais, equipamentos, espaços e profissionais a disposição de ideais, alternativas metodológicas e informações que venham a contribuir para a potencialização dos serviços oferecidos na área físico-esportiva e na vida dos praticantes/clientes Sesc.

Desta forma, encarar esta pesquisa como mais um instrumento de considerável relevância para o fortalecimento da atuação diária dos profissionais de Educação Física perante aos serviços prestados é um passo para a validação da relação entre o novo (quem chega - estagiário) e o cotidiano (quem recebe equipe do DFE). 
Esta pesquisa também denota a importância do olhar macro frente aos alunos praticantes de atividades físicas que se encontram no Sesc. A exemplo estudo sobre grupos de mulheres praticantes da ginástica localizada que além da rotina de exercícios desenvolvida no Sesc Campinas, seus ensejos e conquistas até o momento, pertencem a um cenário social e econômico de obrigações e de cargas emocionais que influenciam e são influenciadas por aspectos físicos. A flexibilidade é um desses aspectos físicos em que temos de ficar atentos, pois, fatores como o sedentarismo, o próprio envelhecimento e estes outros já citados podem comprometê-la e assim causar prejuízo a mobilidade e/ou esforço físico diário de qualquer indivíduo.

Com este pensar o planejamento das aulas físico-esportivas na Atividade Desenvolvimento FísicoEsportivo - DFE podem ser fortalecidas no sentido da modificação das rotinas pedagógicas para se gerar novas experiências, da facilitação ou ampliação do aprendizado e dos resultados almejados.

Diante disto, o artigo procurará apresentar informações significativas que respondam a problemática levantada, na perspectiva dos benefícios físicos que poderão ser adquiridos pela aplicação da técnica de Liberação Miofascial nos praticantes de ginástica localizada e da instrumentalização metodológica para os profissionais de Educação Física do Sesc.

\section{METODOLOGIA}

Trata-se de um estudo do tipo experimental controlado com delineamento longitudinal. Gil, (2007) citado por Córdova diz que o estudo experimental consiste em determinar um objeto de estudo, selecionar possíveis variáveis capazes de influenciá-lo, definir formas de controle e de observação dos efeitos produzida no objeto.

Fonseca acrescenta (2002, p. 38):

A pesquisa experimental seleciona grupos de assuntos coincidentes, submete-os a tratamentos diferentes, verificando as variáveis estranhas e checando se as diferenças observadas nas respostas são estatisticamente significantes. [...] Os efeitos observados são relacionados com as variações nos estímulos, pois o propósito da pesquisa experimental é apreender as relações de causa e efeito ao eliminar explicações conflitantes das descobertas realizadas.

A partir desta percepção, entende-se que o estudo é distribuído em etapas de conhecimento e domínio do método de Liberação Miofascial, levantamento do perfil dos grupos, aplicação da técnica/teste, análise comparativa dos dados, discussão dos resultados e parecer final.

Deste modo, como condição de desenvolvimento deste método de pesquisa houve a necessidade de compreender avaliações físicas das alunas (feitas na própria Unidade), informações da base de dados da central de atendimento do Sesc Campinas e documentos normativos e orientadores do DFE (Matriz Pedagógica 2016, Modelo Político da Atividade 2007 e Classificação Programática 2004) e dominar tecnicamente a aplicação do teste de flexibilidade "sentar e alcançar".

Dentro da proposta de realização do artigo científico, a presente amostra foi com sujeitos adultos do sexo feminino praticantes de Ginástica Localizada, todas matriculadas na Unidade Sesc Campinas. Foram subdivididas em dois grupos, um grupo no período matutino recebendo a técnica de LM no final da aula e outro grupo do horário vespertino/noturno recebendo a intervenção no início da aula, para análise de possíveis variações nos resultados do teste de flexibilidade.

Os critérios utilizados foram: sujeitos do sexo feminino com idade mínima de 35 anos e máxima de 58 anos; disponibilidade para participar das intervenções; cumprimento de $80 \%$ no mínimo das intervenções; exclusão por restrição médica que as impediam de realizar a prática do método, por exemplo, uma fratura recente ou sintoma de dor forte que não fosse de origem muscular. se esquecer de. Esta faixa etária também foi escolhida por ter um maior número de alunas no público total das turmas de ginástica da Unidade do Sesc Campinas.

Para a realização do estudo se fez necessário autorização da Direção Regional do Sesc, portanto foi enviada a carta de aceite (anexo II). Posterior à autorização iniciou-se a abordagem com os grupos para a explicação da pesquisa e preenchimento do termo de consentimento livre e esclarecido (TCLE) (anexo III). 
Com a parte burocrática concluída foi realizada a primeira intervenção com o teste de sentar e alcançar seguindo as Diretrizes do American College of Sports Medicine, 2007, (ACSM), sentando-se no chão, com as pernas estendidas, os pés afastados e descalços, apoiados na plataforma da caixa, braços estendidos à frente, estando uma mão sobreposta à outra. 0 avaliador apoiando a mãos nos joelhos da avaliada sempre que necessário, evitando uma possível flexão das pernas no momento do teste. A avaliada foi orientada a flexionar o tronco e ir lentamente para frente, sem movimentos bruscos, deslizando as mãos sobre a plataforma onde tentou alcançar a maior distância possível. Foram permitidas duas tentativas, sendo registrado o melhor resultado, ainda no mesmo dia foi realizada a primeira sessão de Liberação Miofascial, aplicadas nos pontos gatilhos das regiões dos quadríceps, gastrocnêmicos, ísquiotibiais e lombar, utilizando a técnica de deslizamento profundo, após as 5 intervenções de LM concluídas, na aula seguinte foram realizados novamente os testes de flexibilidade com todas as pesquisadas inclusas no estudo. Tendo como instrumento de coleta o teste sentar e alcançar segundo o protocolo do Banco de Wells (anexo I).

$\mathrm{Na}$ última intervenção também foi feito um grupo focal com cada grupo com o objetivo entender a relevância das intervenções para cada sujeito promovendo uma reflexão sobre os efeitos da Liberação Miofascial na vida diária do indivíduo.

O Serviço Social do Comércio (Sesc) é uma instituição brasileira privada, mantida pelos empresários do comércio de bens, com atuação em todo âmbito nacional, voltada para o bem-estar social dos seus empregados e familiares, aberto à comunidade em geral. Atua nas áreas da Educação, Saúde, Lazer, Cultura e Assistência. Foi criado em 1946, no dia 13 de setembro, pelo Decreto-Lei $n^{\circ}$ 9.853, em que o Presidente Eurico Gaspar Dutra autoriza a Confederação Nacional do Comércio a cria-la, tendo com o objetivo de instituição proporcionar o bem-estar e qualidade de vida para os respectivos beneficiários. segundo Soares (1994 e 1998), Darido e Rangel (2005), pode se adquirir força, corpos saudáveis e ágeis. Na matriz pedagógica do DFE - DR/Goiás utilizada em 2016 esta modalidade tem como objetivos melhorar a consciência corporal, coordenação motora, resistência aeróbia, resistência anaeróbia; desenvolver resistência muscular localizada e socialização entre os alunos. Tendo como conteúdo: flexibilidade; controle respiratório; relaxamento; força muscular; resistência aeróbia e anaeróbia; resistência muscular localizada; coordenação motora e alongamento. Sendo aplicável a alunos a partir dos 15 anos completos, sem nenhuma restrição médica para com a modalidade.

\section{DESENVOLVIMENTO}

As turmas de ginástica localizada no Sesc Campinas apresentam um total de 47 alunas matriculadas. Destas deste quantitativo, alunas 24 se enquadraram nos critérios de seleção para participar do estudo. Após o teste inicial e as 5 intervenções, tivermos os dados coletados de 13 amostras finais nos testes de flexibilidade, avaliações físicas e da base de dados da central de atendimentos da Unidade.

Após a análise dos dados esse grupo de 13 amostras apresentou que possui uma média de idade de 46 anos. Em relação ao tempo que estão matriculadas na modalidade de ginástica localizada foi encontrada uma média de 32 meses ininterruptos de aula, entre elas a aluna com mais tempo de pratica na modalidade iniciou em 2010.

Em relação à modalidade que as alunas frequentam podemos ver a seguir no gráfico 1: 
Gráfico 1- modalidades que as alunas praticam na unidade.

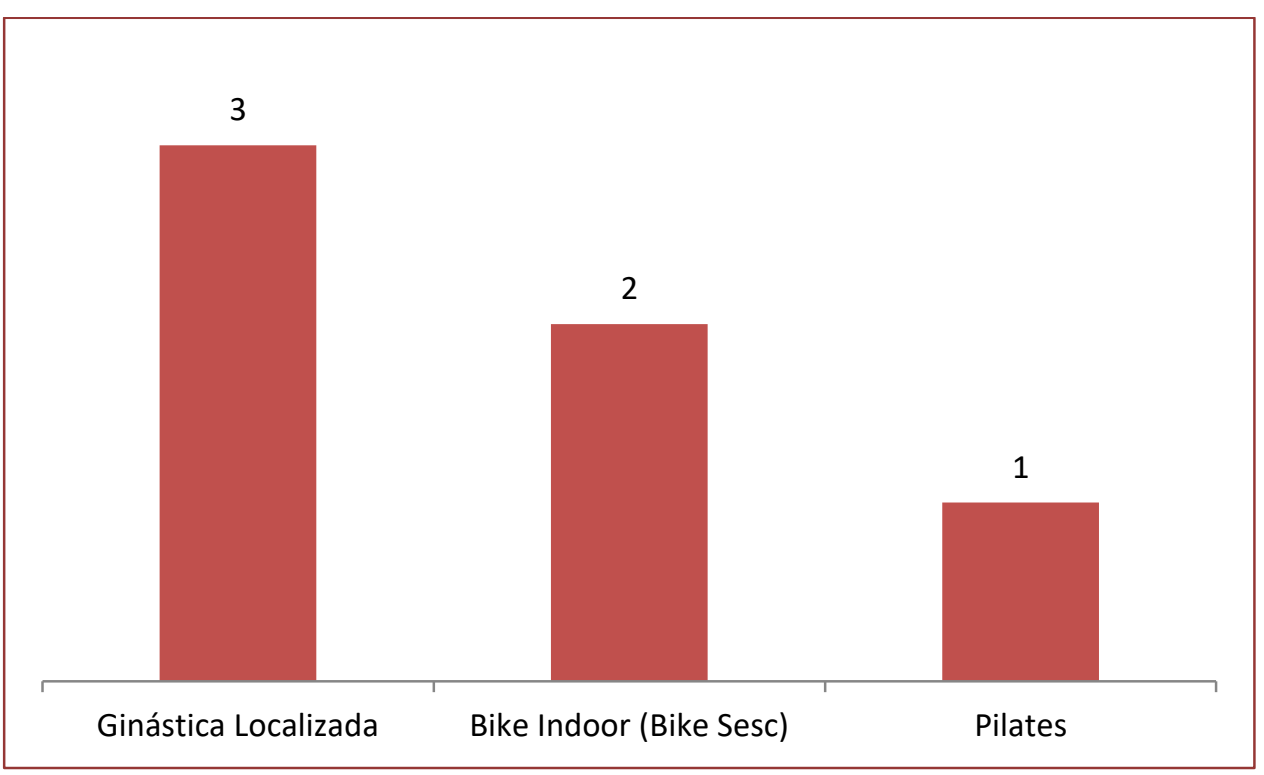

O gráfico 1 apresenta que três alunas que fazem outra modalidade além da ginástica localizada. Dentre elas duas fazem Bike Indoor (Bike Sesc) e uma faz Pilates. Não foi identificada a prática de outras atividades físicas fora do Sesc.

Outro dado relevante a ser ressaltado é a média salarial mensal individual de cada aluna, foi encontrado o valor de $\mathrm{R} \$ 1473,88$. A categoria de classificação das alunas também mostrou uma informação importante sendo 8 comerciários, 7 dependentes e nenhum usuário como podemos ver no gráfico 2 .

Gráfico 2- Modalidades praticadas pelas amostras.

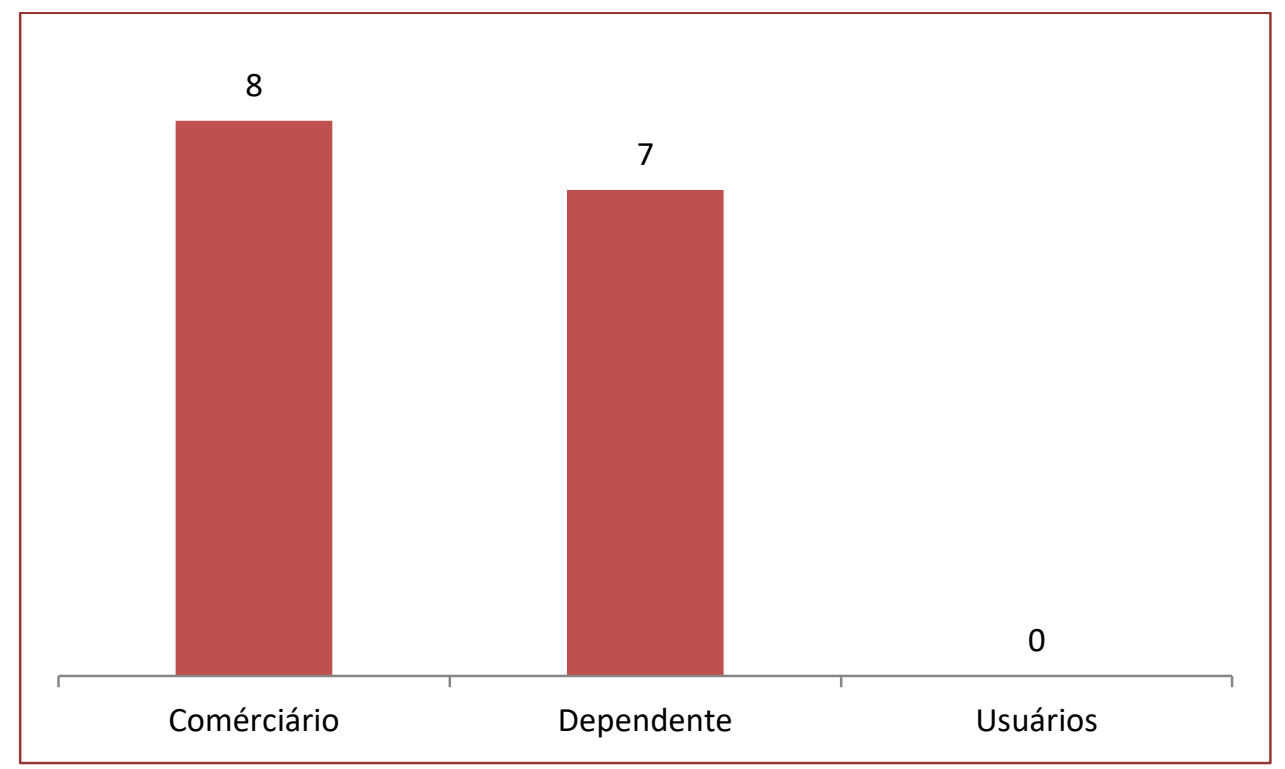

Quando o cliente do Sesc inicia sua participação no DFE ele é questionado na avaliação física sobre seus objetivos e possíveis resultados pretendidos com a pratica da modalidade escolhida, como vemos no gráfico abaixo sobre os objetivos das alunas que participaram da pesquisa. 
Gráfico 3- objetivos das alunas na pratica da modalidade escolhida

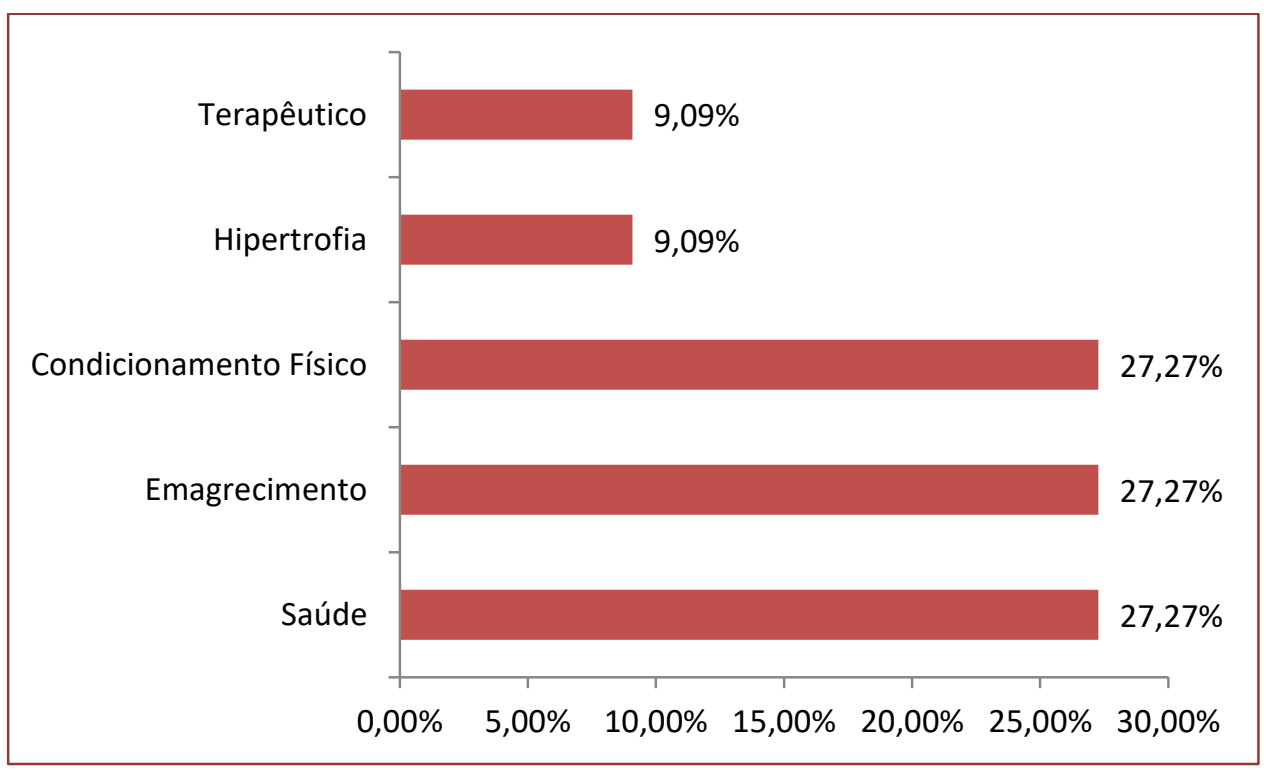

Do total grupo, 27,27\% falou que seu objetivo era saúde, 27,27\% emagrecimento, 9,09\% hipertrofia, $27,27 \%$ condicionamento físico e $9,09 \%$ responderam que estavam na atividade com objetivos terapêuticos (prescrição médica). Durante a avaliação física as alunas podem escolher quantos objetivos quiserem, por este motivo este dado é muito relevante no âmbito de mostrar que a maioria das alunas tem como objetivo aspectos advindos de um pensamento de corpo saudável. Para pessoas do senso comum que não dominam um conceito de saúde bem elaborado, um corpo magro e com bom preparo físico é referência de uma pessoa com saúde em dia.

Seria também relevante considerar que este grupo de mulheres está contido em um cenário, conforme citado por Barbieri 2008, de vidas compostas por vários papéis (a mãe, a dona de casa, a profissional entre outros), o que acaba comprometendo-as em grau excessivo de estresse. Isto pode gerar regiões de tensão no corpo afetando negativamente sua estrutura muscular e articular. Isto quer dizer para os resultados encontrados o efeito/carga social e econômica influenciam diretamente no quadro físico em que essas mulheres chegam para praticar qualquer atividade física no Sesc.

Com base neste perfil do grupo, os dados adquiridos pela aplicação do teste de flexibilidade ("Sentar e Alcançar" para mulheres) tiveram como referência classificatória o seguinte quadro:

\begin{tabular}{|c|c|c|c|c|c|}
\hline \multirow[b]{2}{*}{ Mulheres Classificação } & \multicolumn{5}{|c|}{ Idade (anos) } \\
\hline & $20-29$ Anos & $30-39$ Anos & $40-49$ Anos & $50-59$ Anos & $60-69$ Anos \\
\hline Precisa melhorar & $\leq 27 \mathrm{~cm}$ & $\leq 26 \mathrm{~cm}$ & $\leq 24 \mathrm{~cm}$ & $\leq 24 \mathrm{~cm}$ & $\leq 22 \mathrm{~cm}$ \\
\hline Regular & $28-32 \mathrm{~cm}$ & $27-31 \mathrm{~cm}$ & $25-29 \mathrm{~cm}$ & $25-29 \mathrm{~cm}$ & $23-26 \mathrm{~cm}$ \\
\hline Bom & $33-36 \mathrm{~cm}$ & $32-35 \mathrm{~cm}$ & $30-33 \mathrm{~cm}$ & $30-32 \mathrm{~cm}$ & $27-30 \mathrm{~cm}$ \\
\hline Muito bom & $37-40 \mathrm{~cm}$ & $36-40 \mathrm{~cm}$ & $34-37 \mathrm{~cm}$ & $33-38 \mathrm{~cm}$ & $31-34 \mathrm{~cm}$ \\
\hline Excelente & $\geq 41 \mathrm{~cm}$ & $\geq 41 \mathrm{~cm}$ & $\geq 38 \mathrm{~cm}$ & $\geq 39 \mathrm{~cm}$ & $\geq 35 \mathrm{~cm}$ \\
\hline
\end{tabular}

Fonte: Diretrizes do ACSM para os testes de esforço e sua prescrição / American College of Sports Medicine: Rio de janeiro: Guanabara 7ª edição, 2007.

A partir do teste de flexibilidade foi obtido o resultado de $28 \mathrm{~cm}$ como média geral de todas as amostras, que de acordo com a classificação das Diretrizes do Colégio Americano do Esporte é demonstrado como nível regular.

Depois de separar as amostras nos dois grupos alvos, o grupo 1 que recebeu a Liberação Miofascial antes de iniciar o treino teve a média de $29 \mathrm{~cm}$ no teste de flexibilidade. 0 grupo 2 que recebeu a Liberação 
Miofascial após o treino teve a média de $27 \mathrm{~cm}$ no teste de flexibilidade. Como ambos os grupos apresentaram a classificação regular é evidente que a técnica pode reestabelecer, potencializar ou manter a mobilidade musculo-articular. E que para a obtenção de resultados mais categóricos torna-se necessário um trabalho a médio ou longo prazo.

Como vimos em Dantas 2010, o benefício desta qualidade física proporciona ao indivíduo capacidade de desempenhar atividades de vida diária com mais qualidade e segurança, tornando importante de ser trabalhada ao longo da vida. Por este motivo, a flexibilidade poderia ser tratada com mais atenção e frequência nas modalidades oferecidas pelo Sesc, ratificando princípios presentes no Módulo Político da Atividade do Desenvolvimento Físico-Esportivo (MPADFE) de 1999 ao referir sobre o princípio da vida ativa:

"As práticas físico-esportivos devem procurar despertar a consciência dos indivíduos para uma vida ativa e salutar, a partir da sua pratica regular e permanente, visando a potencialização e a preservação das capacidades físicas, funcional e psicossocial do indivíduo na perspectiva da qualidade de vida."

Com esses fatores citados anteriormente torna importante à busca de ferramentas e métodos que consigam suprir estas necessidades físicas dos alunos e programáticas do MPADFE. Dentro destas ferramentas se encontra a liberação miofascial utilizada na (s) ultima(s) década (s) com um dos objetivos de contribuir para a flexibilidade muscular (FRAGA 2015). André (2013) cita como uma ferramenta fundamental nos tratamentos do sistema musculoesquelético, devolvendo maior liberdade e organização dos movimentos, diminuição de dores e alinhamento postural. Souza e Mejia (2011) acrescenta que a mesma funciona "muitas vezes como uma massagem, o que por consequência direta já proporciona sensação de alívio e "bem-estar".

Os resultados do teste de flexibilidade são apresentados nos gráficos a seguir. No gráfico 4 são apresentados os resultados do teste inicial e final do grupo que recebeu a LM no pré-treino.

Gráfico 4 - Comparativo das Médias dos Níveis de Flexibilidade do momento pré e pós-aplicação da LM (Grupo 1)

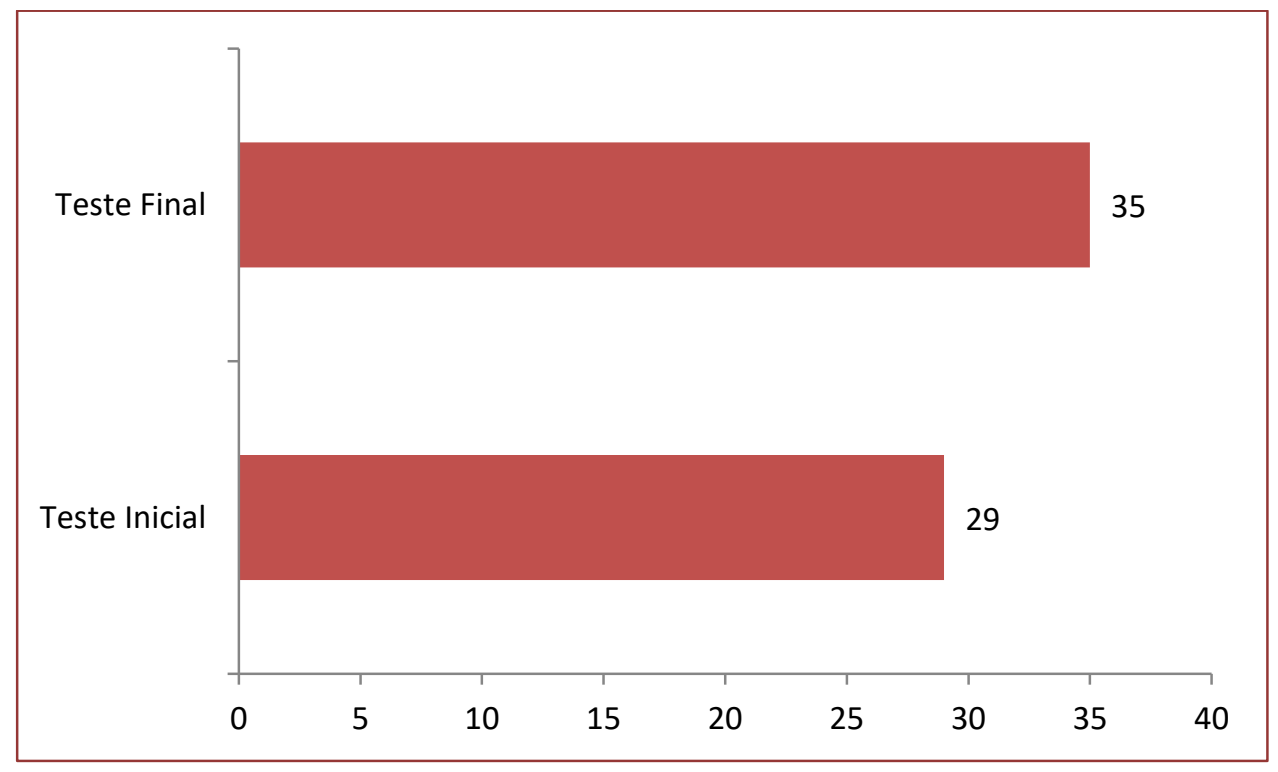


Os resultados apresentados no gráfico 5 acima indicam que o grupo que recebeu a liberação miofascial no momento pré-treino, apresentou o teste final com valores médios dos níveis de flexibilidade maiores estatisticamente ao teste inicial tendo resultado médio de 29,0 cm passando para $35,0 \mathrm{~cm}$, o que corresponde a um aumento de $6 \mathrm{~cm}$. Este resultado vai de encontro com a percepção já citada anteriormente por Fraga (2015) e André (2013).

Arruda (2010), também cita o benefício da liberação miofascial como uma ferramenta benéfica para auxiliar na obtenção de resultados positivos e duradouros mediante a flexibilidade de praticantes de atividade física.

Portanto essa técnica pode sim ser uma forma de intervenção mais adequada para auxiliar na obtenção de resultados mais duradouros, pois age sobre o tecido conjuntivo, trabalha a elasticidade do corpo e ao mesmo tempo a função estática da fisiologia da locomoção, dessa forma promove um tratamento global ao o menor tensionamento ativo ou passivo gerando repercussões sobre todo o conjunto.

Este benefício não aconteceu da mesma forma no resultado das amostras do grupo 2.0 gráfico 5 mostra que não ouve mudança no valor de flexibilidade das alunas, como podemos ver abaixo.

Gráfico 5 - Médias dos Níveis de Flexibilidade do momento pré e pós-aplicação da LM (Grupo 2)

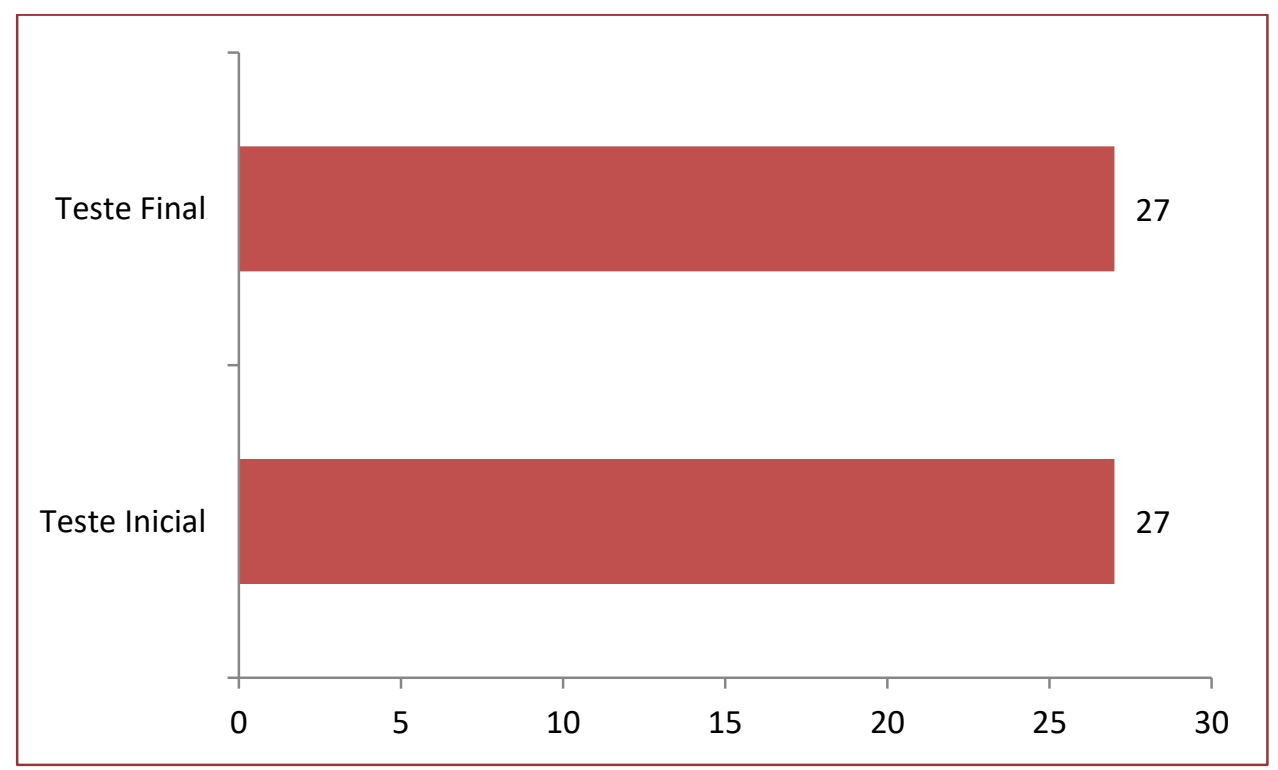

Os resultados apresentados no gráfico 5 indicam que o grupo que recebeu a liberação miofascial no momento pós-treino, apresentou o teste final com valores médios dos níveis de flexibilidade iguais estatisticamente ao teste inicial tendo resultado médio de $27,0 \mathrm{~cm}$ e o resultado do teste final de $27,0 \mathrm{~cm}$, apresentando diferença significativa no resultado da média no teste de flexibilidade pré e o pós- teste no grupo que recebeu a Liberação Miofascial antes do treino, passando do nível regular de flexibilidade para o nível bom, entretanto no grupo que recebeu a Liberação Miofascial após o treino manteve seu resultado estável ao teste inicial, ambos no nível regular de flexibilidade pela tabela de classificações do teste de sentar e alcançar de mulheres segundo as Diretrizes do ACSM para os testes de esforço e sua prescrição / American College of Sports Medicine: Rio de janeiro: Guanabara 7ạ edição, 2007 presente no ANEXO I.

A pequena quantidade de estudos acerca da Liberação Miofascial limitou o poder de argumentação do estudo na busca de explanação sobre qual motivo pode ser relevante para proporcionar tal diferença nos resultados. Também é importante reconhecer a limitação deste trabalho no sentido de ser um estudo de conclusão de curso e de conclusão de estágio, por este motivo foi necessário optar por um recorte bem especifico referente ao objeto de pesquisa. 
Mesmo assim é possível apontar alguns direcionamentos com respaldada relevância. deles é referente à amplitude de movimento sendo aumentada com a Liberação Miofascial durante o início do treino. Este provável aumento influenciou no alongamento natural dos músculos antagonistas durante a fase de coativação ou co-contração como cita Alter (2010, pg.96) "co-ativação ou co-contração refere-se à contração simultânea do agonista e do antagonista a um nível variável, com dominância do primeiro, que produz o movimento externo". Ou seja, quando o musculo agonista se contrai o antagonista se alonga e atua como estabilizador do movimento.

Como cita Fornarsari (2001),

O músculo antagonista tem como função se contrapor a um determinado movimento, ou de realizar uma ação contraria a ele; portanto músculo antagonista é aquele que se contrapõe diretamente a ação realizada pelo agonista ou aquele que realiza a ação contraria ao agonista".

Desta forma, durante as atividades ministradas, posteriormente, nas aulas de ginástica localizada sempre que há uma articulação em seus respectivos movimentos contraindo e alongando as musculaturas agonistas acaba acontecendo um alongamento involuntário do músculo antagonista do movimento como citado anteriormente no conceito de " co-ativação ou co-contração". 0 aumento prévio de flexibilidade gerado pela liberação miofascial nos momentos iniciais da aula pode ter resultado na melhora pela soma da Liberação Miofascial e pelo ganho de amplitude dos exercícios executados nas aulas, possivelmente trazendo está variação nos resultados.

Esta variante pode ter sido um fator relevante para a diferença do resultado e infelizmente o estudo ficou limitado em relação a sua avaliação. Porém, o objetivo do estudo era descobrir se havia alguma diferença entre o momento de intervenção e apresentar tal resultado, entretanto existiu outro fator relevante que não era alvo do estudo, mas foi extremamente comentado e ressaltado após cada intervenção. 0 relaxamento das musculaturas que sofreram a Liberação Miofascial foi muito citado e comentado pelas alunas participantes da pesquisa. Por este motivo vale trazer ao estudo seu relato:

Logo após a massagem quando terminou a aula, fui para casa. Chegando lá tomei banho e deitei no sofá para descansar. Quando meu marido pediu para fazer a janta, não consegui me levantar. Me senti tão relaxada e uma sensação tão boa nas pernas que estava muito bom para ter que levantar e subir escadas para ir na cozinha. Tive que pedir para meu filho esquentar a comida do almoço. Muito boa essa massagem, espero que tenha mais vezes na nossa aula. (Aluna 1, do Grupo 2 de amostras.)

Este tipo de relato representa muito bem o questionamento de todas as participantes do estudo. Mesmo sendo de caráter informal durante as intervenções ele se mostrou muito relevante, pois, acontecia com altíssima frequência partindo de todas participantes da intervenção. Estes comentários vão de encontro às ideias já citadas anteriormente neste trabalho por André (2013) e Souza e Mejia (2011).

A relação entre os resultados dos momentos pré-teste e pós-teste foi significante e forte na análise geral e para o grupo experimental. Por este motivo a técnica de liberação Miofascial teve um caráter relevante para as alunas do Sesc, mesmo não tendo elevado o nível de flexibilidade de quem fez a intervenção depois da aula de ginástica. Ela se mostrou uma boa ferramenta de relaxamento para ser utilizada no final das aulas, pois, são técnicas de fácil execução e que não demandam material e estrutura complexa, e que também pode ser aplicada em praticantes de diversas modalidades esportivas quando na exigência ou não de um maior esforço físico. 


\section{CONSIDERAÇÕES FINAIS}

A Liberação Miofascial parece se tratar de uma técnica de melhor eficácia na flexibilidade ao ser introduzida nos momentos iniciais das aulas se tratando dos resultados obtidos nos testes, entretanto ela se mostrou uma ótima ferramenta de relaxamento a ser utilizada no final do treino. Discussões que giram em torno deste assunto quanto ao melhor momento de aplicação para o ganho de flexibilidade, se faz necessárias mais pesquisas para obtenção de dados mais detalhados e fidedignos, além da comprovação de melhores resultados físicos.

Apesar destes aspectos não serem respondidos na pesquisa foi relatado pelo grupo que recebeu a técnica após o treino, relaxamento, diminuição de dor muscular, melhor disposição nas aulas e relaxamento após a intervenção, aspectos que deve ser abordado nas próximas pesquisas para justificar uma maior utilização da técnica pelos professores de educação física como mais uma ferramenta em seus programas de treinamento físico esportivo.

Como a Liberação Miofascial se trata de uma técnica com outros movimentos não se limitando ao utilizado neste estudo, há uma variedades de materiais com fácil aplicabilidade e que já existem na grande maioria nas Unidades do Sesc que atuam com o DFE: bolas de tênis, halteres, bastões de ginástica, barras de pump, bolas de massagem, rolo de E.V.A dentre outros. Novamente, cabe apontar que a técnica de Liberação Miofascial pode ser aplicada em diversas modalidades físicas e esportivas, pois, se mostra como uma boa opção metodológica para as aulas sistemáticas e especiais do DFE.

\section{REFERÊNCIAS}

[1] ALTER, M. J., SALES, D. R. Ciência da flexibilidade $3^{\circ}$ edição. Porto Alegre: Editora ARTMED, 2010.

[2] ANDRÉ, M. L. A. Mobilização miofascial. Disponível em:

http://www.marialuisa.com.br/tecnicas/liberacaomiofascial. América São Paulo, 2013.

[3] ARRUDA, G. A; STELLBRINK, G; OLIVEIRA, A, R (2010) efeitos da liberação miofascial e idade sobre a flexibilidade de homens, Rev. Researchgate, Londrina, v.18, p. 396-400. Diretrizes do ACSM para os testes de esforço e sua prescrição / American College of Sports Medicine: Rio de janeiro: Guanabara 7a edição, 2007.

[4] FRAGA, S. Lume.ufrgs.br, Auto liberação miofascial no treinamento Físico Revisão de literatura, porto-alegre, p. 5-22, 2015.

[5] FORNASARI, A. C. Manual para estudo da cinesiologia. São Paulo: Editora Manole Ltda, 2001.

[6] LEITÃO, B. Rev Bras Med Esporte Posicionamento Oficial da Sociedade Brasileira de Medicina do Esporte: Atividade Física e Saúde na Mulher, Vol. 6, N. 6 - Nov/Dez, 2000.

[7] RÊGO, M; MARTIN, M; FILHO, D. Rev Neurocienc, Efeitos da Liberação Miofascial Sobre a Flexibilidade de um Paciente com Distrofia Miotônica de Steinert, São Paulo-SP, Brasil, p. 404-409, dez 2012.

[8] RIBEIRO, A; ABAD, C; BARROS, V; NETO, B. Rev Bras Cineantropom, Nível de flexibilidade obtida pelo teste de sentar e alcançar a partir de estudo realizado na Grande São Paulo, p. 416-421,2010. Rubini EC e Gomes PSC. A Titina e suas implicações na elasticidade muscular - breve revisão. Revista Brasileira de Fisiologia do Exercício. 3 (1): 20-25, 2004.

[9] DANTAS, Estélio H. M. Flexibilidade, Alongamento e Flexionamento. 4. ed. Rio de Janeiro: Shape, 1999. p.57207.

[10] SILVA, M; RABELO, T. Rev. Movimentum - Revista Digital de Educação Física, Estudo comparativo dos níveis de flexibilidade entre mulheres idosas praticantes de atividade física e não praticantes, Ipatinga: Unileste-MG - V.1, p. 1-15, Agos./dez. 2006.

[11] SOUZA, M. S. Estudo comparativo entre as técnicas de alongamento ativo x liberação miofascial. Pósgraduação em Fisioterapia em Traumatologia e Reumatologia, Bio cursos - Manaus, 2012.

[12] VASCONCELOS, A; RIBEIRO, D; MACÊDO, C. Rev. Tema, 0 tratamento da flexibilidade pela fisioterapia, Campina Grande, v.7, n. 10\11, p.29-37, 2008.

[13] XIAOQIANG, Z; SHUSHENG, T; HUANG, Q. Rev. Researchgate, Understanding of myofascial trigger points, chin med, v.13, p.1-7, dez 2014. 


\section{Capítulo 3}

\section{A corporeidade Freireana}

\section{Rafael Vieira de Araújo}

Teresa Cristina Barbo Siqueira

Rildo Vieira de Araújo

Resumo: Neste estudo discutiu-se a compreensão da corporeidade na concepção freireana. Utilizou-se como metodologia a pesquisa bibliográfica das obras de Paulo Freire. Este foi categorizado e dividido em três partes: corpo social - corpo consciente; corpo na educação e a luta por corpos conscientes. Objetivou-se identificar a formulação do pensamento de Paulo Freire, sobre a temática corpo. Ressaltou-se a ideia de corpo consciente e a necessidade e a importância de repensar o corpo na educação.

Palavras-Chave: corporeidade; corpo na educação; corpos conscientes. 


\section{INTRODUÇÃO}

O presente estudo inaugura um diálogo com as obras de Paulo Freire com o intuito de compreender os corpos conscientes, oprimidos, vencidos e vazios, conforme Freire (2011, p.45), "o corpo molhado de nossa história".

Assim, discutiremos ${ }^{2}$ a corporeidade na educação a partir de Paulo Freire, em suas diversas obras nas quais abordou de forma crítica e aprofundada, possibilidades do processo de formação humana de corpos conscientes, por meio da Educação libertadora, progressista e popular.

Ao encontro desta proposta, Paulo Freire sugere "o círculo de cultura" como espaços epistemológicos de diálogo, isto é, se aprende e se ensina com o outro e de corpo inteiro.

Assim, optar em dialogar com os livros de Paulo Freire não é uma opção aleatória, e sim uma decisão política, ou seja, uma concepção de educação que é política.

Desse modo, questiona-se como formar com os educandos "corpos conscientes"?

\section{METODOLOGIA}

Ao investigar sobre a noção de corpo(s) consciente(s) recorreu-se a pesquisa bibliográfica, o conceito de corpos conscientes aparece em algumas obras de Freire e pesquisas que abordaram sobre essa temática, vale destacar o artigo de Gonçalves ${ }^{3}$, com o tema "A noção de corpo(s) consciente(s) na obra de Paulo Freire" que apresentou a sequência dos anos de publicação das obras que abordaram o tema corpos conscientes.

Considerando a estratégia adotada pelo autor Gonçalves procurou-se neste texto dialogar com algumas obras de Paulo Freire sobre a temática do corpo, discutindo dialeticamente o conceito de corporeidade e Freire deixava claro sobre a importância de repensar o corpo na educação.

Portanto, este diálogo freireano contribui para a compreensão da corporeidade ${ }^{4}$ dos educandos, a partir da reflexão teórica sobre a educação do corpo.

\section{O CORPO SOCIAL - CORPO CONSCIENTE}

O corpo constitui objeto de estudo e pesquisa de diferentes áreas de conhecimentos. Compreendê-lo é um exercício intelectual complexo no campo das ciências humanas, biológicas, exatas e principalmente o corpo em movimento na Educação Física. Desse modo, o corpo é dialético, histórico, uma expressão material/ espiritual na relação com a natureza/cultura ${ }^{5}$ e o social, pois a realidade social é a base de reflexão e transformação para sujeitos conscientes que dão vida, sentidos e significados ao corpo.

A contribuição da dialética de Paulo Freire com a temática do corpo é expressa na obra Pedagogia do Oprimido. Como explicita Gadotti (2008, p.114), "falar do oprimido" é lembrar que "o oprimido é o corpo". A palavra "corpos conscientes" apareceu, pela primeira vez, nas palavras de Paulo Freire, ao tratar sobre concepção bancária e contradição educador-educando, Freire (2005, p.72) denuncia "[. ] uma dicotomia inexistente homens-mundo. Homens simplesmente no mundo e não com o mundo e com os outros. Concebe a sua consciência como algo espacializado neles e não aos homens como "corpos conscientes. "

\footnotetext{
2 Este texto foi elaborado a partir da dissertação de mestrado do autor Araújo (2015).

3 Conforme (Gonçalves, p.1,) ver as obras de Paulo Freire, nas quais se destaca a noção de corpo(s) consciente(s), apresentadas de acordo com a sequência dos anos de publicação.

4 "A corporeidade implica a inserção de um corpo humano em um mundo significativo; implica a relação dialética do corpo consigo mesmo, com outros corpos expressivos e com os objetos de seu mundo." (SIQUEIRA, Teresa C.B. 2001, p.59).

5 Conforme Chauí (1997, p. 307), somos seres culturais-criamos a linguagem, o trabalho, a sociedade, a religião, a política, a ética, as artes e as técnicas, a filosofia e as ciências.
} 
Constatou-se a compreensão do corpo como cultura quando Freire comentou sobre as marcas do exílio em sua vida, presente na Pedagogia da Esperança (2011, p.17) "[. ] com o corpo molhado de história, de marcas culturais, de lembranças, de sentimentos, de dúvidas, de sonhos rasgados, mas não desfeitos, de saudades de meu mundo." Uma analogia pode ser feita nos dias atuais, pois a classe trabalhadora vivencia outro tipo de situação, ou seja, é exilada desde o nascimento, da ausência do lazer, da moradia, da cultura, do teatro, da escola, do esporte, da política, da economia e vive na alienação sustentada pelo opressor.

Em Freire e Faundez (1985, p.15), os autores nos apresentam o diálogo que o corpo estabelece socialmente e o problema do distanciamento da corporeidade e aponta: "[. ] o corpo humano, velho ou moço, gordo ou magro, não importa de que cor, o corpo consciente, [...] é o corpo que luta, é o corpo que ama, que odeia, é o corpo que sofre, é o corpo que morre, é o corpo que vive!"

A citação reafirmou a compreensão progressista de Paulo Freire sobre o corpo e defendeu a luta das novas gerações contra a alienação de corpo perfeito, mas um corpo consciente.

0 processo de consciência, na perspectiva freireana, apresenta níveis de consciências (intransitiva, transitiva ingênua, transitiva crítica) que não são determinadas de forma linear e sim espiraladas.

Então, para Freire (1990), a corporeidade é formada pela consciência do mundo e não a partir da consciência de si ou da falsa consciência do mundo. Nessa compreensão, é nas relações em que o mundo da consciência no olhar sociológico de Paulo Freire se constitui a partir de uma preocupação essencialmente educativa, denominada consciência social.

Dessa forma, o corpo consciente na existência humana se torna mais intenso e mais rico. Freire (1996, p. 20) afirma que "[...] minha consciência não está no cérebro, nem ela está nos pulmões ou no coração. Minha consciência sou eu, corpo. E meu corpo se constitui corpo consciente na medida em que se relaciona com outros humanos".

Freire abordou sobre os estados da consciência nos livros: Ação cultural para a liberdade e outros escritos (1981) e Educação como prática da liberdade (1983). Neles, explicou que a consciência intransitiva ou "semi-intransitiva" é a condição do sujeito, cuja vida é meramente biológica que, em sua realidade, não tem a capacidade de objetivá-la e conhecê-la criticamente.

O sujeito, na busca intencional por transformações de sua condição humana de vida, tem no diálogo com os outros e no compromisso social, atingir outro nível: o da consciência transitiva ingênua. Conforme Freire (1983, p. 60), “[...] a consciência transitiva é, porém, num primeiro estado, preponderantemente ingênua".

Portanto, a partir do processo de humanização e transformação a consciência transitiva crítica é o processo do sujeito para interpretar a realidade concreta e a capacidade de pensar, refletir, posicionar, decidir e fazer opções e ações conscientes, ou seja, lutar pela sua autonomia intelectual e libertação corporal. Freire (1983, p. 61) exemplifica que a consciência transitiva crítica caracteriza-se "[...] pela recusa a posições quietistas. Por segurança na argumentação. Pela prática do diálogo e não da polêmica".

\section{CORPO NA EDUCAÇ̃̃O}

A educação é compreendida dialeticamente a partir da sociedade e da concepção de homem dentro de uma cultura. Os saberes e os conhecimentos historicamente acumulados foram sistematizados e institucionalizados pela escola.

Como forma de romper com a educação bancária no Livro Pedagogia do Oprimido, Freire (2005) propôs uma metodologia, processo educativo-libertador, a partir da problematização da realidade concreta dos educandos que definiu como temas geradores com base epistemológica, pedagógica e política.

Na mesma direção ao refletir sobre a corporeidade dos educandos, deve-se contextualizar a história desses corpos por meio da leitura de mundo e isso implica considerar o corpo do sujeito educando influenciado e maltratado pela sociedade do capital. Assim, o papel do educador é desafiar a curiosidade ingênua do aluno em relação a seu próprio corpo no mundo. 
Na leitura do livro Educação na Cidade (1991), quando Freire, em diálogo com Gadotti, enfatizou que o jovem de hoje tem a liberdade de ressignificar o corpo, uma vez que lhe é permitido modelar, exercitar, transformar o seu próprio corpo.

[...] é que meu corpo consciente está sendo porque faço coisas, porque atuo, porque penso já. A importância do corpo é indiscutível; o corpo move-se, age, rememora a luta de sua libertação, o corpo afinal deseja, aponta, anuncia, protesta, se curva, se ergue, desenha e refaz o mundo. Nenhum de nós, nem tu, estamos aqui dizendo que a transformação se faz através de um corpo individual (FREIRE, 1991, p. 92).

Por isso, o interesse deste estudo sobre o corpo do educando que historicamente foi oprimido e a responsabilidade do educador e da sociedade em contribuir para formar corpos conscientes.

\section{ALGUMAS REFLEXÕES: A LUTA POR CORPOS CONSCIENTES}

Espera-se que esta pesquisa incite o debate crítico acerca da educação do corpo nas instituições educativas, em especial o debate que pauta sobre a corporeidade- subjetividade do educando trabalhador, visando não somente à construção de corpos conscientes como também a sua autonomia.

O corpo precisa ser ressignificado em todos os espaços formativos. No caso da instituição escolar, o corpo necessita ser pedagogizado, desvelado, desconstruído, desmitificado com o intuito de superar a dicotomia entre trabalho manual e trabalho intelectual e a cisão corpo e mente, possivelmente levando o educando a estranhar os sentidos e significados de corpo, de um corpo sequestrado pelo trabalho, ignorado pela escola e pelas dificuldades de vida cotidiana, tornando-os conscientes.

Só assim, com corpos-conscientes, poderíamos lutar a boa batalha na vida e agir com o mundo nos fazendo cada vez um ser mais, sujeitos completos em sua corporeidade-subjetividade.

\section{REFERENCIAS}

[1] ARAÚJO, Rafael Vieira de. A corporeidade-subjetividade dos educandos trabalhadores do Proeja FIC. 2015. 225f. Dissertação (Mestrado) - Pontifícia Universidade Católica de Goiás, Programa de Pós-Graduação Stricto Sensu em Educação, PUC-Goiás, Goiânia, 2015.

[2] CHAUI, Marilena. Convite à Filosofia. 2. ed. São Paulo: Ática, 1997.

[3] FREIRE, Paulo. Pedagogia da Esperança: um reencontro com a Pedagogia do Oprimido.São Paulo: Paz e Terra, 2011.

[4] FREIRE, Paulo. Pedagogia do Oprimido. Rio de Janeiro: Paz e Terra, 2005.

[5] FREIRE, Paulo. Reencontrar o corpo. In: NOGUEIRA, Adriano (Org.). Reencontrar o corpo: ciência, arte, educação e sociedade. Taubaté: Cabral, GEIC, 1996.

[6] FREIRE, Paulo. A Educação na Cidade. São Paulo: Cortez, 1991.

[7] FREIRE, Paulo. LOPES, Joana; NOGUEIRA, Adriano S.; FREIRE, Paulo. Corpo e dança dos povos. Êxito Comunicação e Promoção, 1990. Entrevista. Disponível em: <http://acervo. paulofreire.org/xmlui/handle/7891/3208>. Acesso em: 11 mar. 2015.

[8] FREIRE, Paulo; FAUNDEZ Antônio. Por uma Pedagogia da Pergunta. Rio de Janeiro: Paz eTerra, 1985.

[9] FREIRE, P. Educação como prática da liberdade. 14. ed. Rio de Janeiro: Paz e Terra, 1983.FREIRE, Paulo. A Ação cultural para a liberdade. 5. ed. Rio de Janeiro: Paze Terra, 1981.

[10] GADOTTI, Moacir. In: ALMEIDA, Danilo Di Manno de. Corpo e pedagogia em Paulo Freire: uma conversa inicial com Moacir Gadotti. Universidade Metodista de São Paulo. Educação\& linguagem, n. 17 105-116, jan.jun. 2008. Disponível em: <https://www.metodista.br/ revistas/revistas-ims/index.php/EL/issue/ view/ 11>. Acesso em: 17 jan. 2014.

[11] GONÇALVES, Luiz Gonzaga. A noção de corpo(s) consciente(s) na obra de Paulo Freire. Disponível em: <http://www.cppnac.org.br/wp-content/uploads/2012/09/Corpo-Consciente.pdf >. Acesso em: 12 maio 2016.

[12] SIQUEIRA, Teresa Cristina Barbo. Elementos para uma Fenomenologia da Corporeidade em MerleauPonty. 2001. Dissertação (Mestrado em Filosofia) - Faculdade de Filosofia, Universidade Federal de Goiás, Goiânia. 


\section{Capítulo 4}

O circo adaptado como ferramenta de desenvolvimento integral para pessoas com deficiência

\section{Carina Lopes Moreira}

\section{Tatiana Robles Santiago}

Aline Aparecida Ribeiro

Larissa Henrique Ferrari

Nathaly Freitas de Souza

Resumo: 0 processo de inclusão social de pessoas com deficiência considera muito além de suas condições orgânicas, mas prevê, também, que o meio seja adequado de maneira a acolher o indivíduo em suas diferentes necessidades, promovendo pleno acesso às políticas sociais, de lazer, cultura e uso de produtos e serviços. Diante disto, o presente trabalho vem apresentar as diferentes possibilidades de participação e desenvolvimento de pessoas com deficiência através da prática de atividades circenses, trazendo informações sobre a forma como se apresenta hoje a proposta do circo contemporâneo e objetivando apresentar um relato de experiência da realização de aulas de circo adaptado para pessoas com deficiência numa escola de atividades circenses, chamada Casa do Circo, na cidade de Bauru/ SP e, também, refletir sobre as contribuições dessas atividades para essa população. Por meio de relato estruturado apresenta-se a forma como essas aulas ocorrem desde a procura até a sua realização e aponta os resultados que demonstram os benefícios vivenciados por todas as partes por meio da realização do circo adaptado como forma de ampliar os espaços de exploração e descobertas a partir do corpo e das atividades circenses, de maneira estruturada para atender às diferentes necessidades.

Palavras-chave: Atividades Circenses; Circo; Atividade Motora Adaptada; Desenvolvimento; Inclusão Social. 


\section{INTRODUÇÃO}

A história da relação da sociedade com a pessoa com deficiência, passa pelas diferentes concepções vinculadas aos paradigmas de atendimento ao deficiente até chegar ao paradigma de suporte, que tem como base a perspectiva interacionista. Tal paradigma dá origem ao conceito de inclusão social, em que são consideradas, além das condições orgânicas do sujeito, as normas e expectativas do meio social, por isso mesmo entende que o meio precisa modificar-se para acolher a pessoa com deficiência, oferecendo os suportes necessários para sua efetiva participação na sociedade (POKER, 2017). A prática da inclusão social parte do princípio de que, para inserir todas as pessoas, a sociedade deve ser modificada de modo a atender às necessidades de todos os seus membros: uma sociedade inclusiva não admite preconceitos, discriminações, barreiras sociais, culturais e pessoais. Nesse sentido, a inclusão social das pessoas com deficiência, significa possibilitar a elas, respeitando as necessidades próprias da sua condição, o acesso aos serviços públicos, aos bens culturais e aos produtos decorrentes do avanço social, político, econômico e tecnológico da sociedade (MINISTÉRIO DA SAÚDE, 2008).

Sabe-se que devido às características físicas, sensoriais, psíquicas ou comportamentais há uma busca e frequência constante nos serviços de saúde e reabilitação por parte das pessoas com deficiência ou transtornos do desenvolvimento devido às necessidades de receber apoio em relação aos distúrbios neuromotores, cognitivos, funcionais e/ou biomecânicos e que a realização de acompanhamento com profissionais especializados nas áreas de fisioterapia, fonoaudiologia, psicologia, terapia ocupacional, entre outros, são importantes para o bom desenvolvimento das funções de crianças com transtornos e deficiências (ARAUJO \& FILHO, 2015), porém, é importante ressaltar que a participação da pessoa com deficiência na sociedade deve ir além de suas necessidades básicas iniciais como direito à saúde e educação, mas também devem ser consideradas as atividades esportivas, culturais, artísticas e de lazer como essenciais para o desenvolvimento integral do ser humano enquanto ser biopsicossocial (MAZZOTTA \& D'ANTINO, 2011) e, por isso, aqui, serão relatadas atividades circenses adaptadas de forma colaborativa e como instrumento de desenvolvimento integral para essas pessoas.

As atividades circenses foram, historicamente, disseminadas como uma forma de expressão artística, que tem como um dos elementos principais a ação do corpo em movimentos e performances em interação com equipamentos, acrobacias no solo ou em conjunto com outras pessoas (SEIBEL, 2005). Hoje, no circo moderno, encontramos atletas, artistas e demais pessoas que o buscam como forma de recreação e lazer e, é possível observar que, como cita Baroni (2006), a "atividade circense é expressão e vivência" e não "pré determinação dos gestos", colocando a experiência da arte circense dentro da possibilidade de movimento de cada indivíduo, não de forma mecânica, mas sim, como um aprendizado que, utilizando-se da força, equilíbrio e de todas as demais expressões do corpo, permite uma manifestação livre do movimento.

Diante disto, o presente estudo tem como objetivo relatar a experiência do trabalho desenvolvido na Casa do Circo de Bauru com as atividades de circo adaptado para crianças com deficiência e refletir sobre as contribuições dessas atividades para essa população.

\section{MÉTODOS}

As atividades de circo adaptado nasceram a partir da parceria entre uma Terapeuta Ocupacional e a Casa do Circo, escola de atividades circenses localizada em Bauru. Com início em 2016, as atividades de circo adaptado visam contemplar pessoas com diferentes necessidades individuais, decorrentes de deficiências, transtornos ou atrasos no desenvolvimento.

Inicialmente os atendimentos começaram voltados a crianças que se encontram no Transtorno do Espectro Autista (TEA), sendo, ainda hoje, a clientela que mais procura os atendimentos.

O fluxo para receber e atender a essa população inicia-se com o contato inicial feito pela família, que toma conhecimento principalmente a partir da divulgação das atividades na página da escola na internet. A partir daí, é agendado um horário individual do aluno com a profissional de terapia ocupacional e professora de atividades circenses que realiza uma coleta de informações sobre a patologia e desenvolvimento da criança, bem como, observa como se dá a adaptação da criança ao ambiente e suas possibilidades iniciais frente às atividades propostas. Depois de estabelecidos os acordos sobre horário e dias das aulas com a família, iniciam-se as aulas de circo adaptado.

As aulas são estruturadas dentro das possibilidades da criança e envolvem atividades como alongamentos, brincadeiras e jogos com circuitos e obstáculos, experimentação e aprendizado das atividades circenses como trapézio, rola-rola, bambolê, cama elástica, lira, tecido acrobático, malabares (bolinhas, pratos, aros), 
pé de lata, perna de pau, túnel suspenso, slackline, entre outros. É importante ressaltar que o ritmo das atividades, altura dos equipamentos, materiais e condução da aula é feito de maneira a atender às necessidades individuais do aluno e estimular suas potencialidades atuais, de forma a obter avanços e envolver o participante voluntariamente no ambiente e nas propostas da aula, possibilitando desenvolver suas habilidades psicomotoras e sensoriais, além da possibilidade de dar continuidade com a inserção futura em aulas de grupo se este demonstrar interesse e progressos a partir da aula adaptada.

As aulas são particulares e o custo da aula é de responsabilidade da família, porém, há também, no momento, um grupo em andamento como forma de projeto de pesquisa, não havendo, neste, nenhum custo por parte do aluno para realização das aulas.

\section{RESULTADOS E DISCUSSÃO}

No presente há, na Casa do Circo em Bauru, 6 alunos realizando aulas na forma de circo adaptado e 2 alunos inseridos em aula regular que passaram previamente pela aula de circo adaptado. É possível verificar que as atividades realizadas estimulam o interesse destes alunos e de seus familiares em dar andamento nas aulas, bem como ampliam a possibilidade dos profissionais e demais alunos da escola de atividades circenses buscarem estratégias e novas dinâmicas para o ambiente e aulas visando receber essa população, o que impacta positivamente no crescimento e na qualidade do serviço oferecido. Realizar aulas com estrutura adaptada voltadas às necessidades do aluno com deficiência faz parte do processo de inclusão previsto pelo Ministério da Saúde, que, conforme já citado, prevê que a pessoa com deficiência tenha acesso integral aos serviços públicos, culturais e bens sociais (MINISTÉRIO DA SAÚDE, 2008).

É importante ressaltar que as aulas de circo adaptado proporcionam ao indivíduo com deficiência a possibilidade de desenvolver as habilidades previstas em todas as aulas, composta de aspectos trazidos pelo circo contemporâneo tanto no âmbito de lazer, onde, segundo Bortoleto e Machado (2003), a prática é mais lúdica e não se centra apenas na especificidade da atividade, mas na sensação de prazer, diversão e satisfação, como também no âmbito educativo que, conforme descrito pelos mesmos autores, tratam de uma prática num nível de "iniciação", com aspectos relativos à expressão corporal, à estética do movimento e no aumento dos conhecimentos da cultura corporal e, no âmbito profissional, acrescentando além do que já foi citado, um enfoque prático de rendimento que requer desenvolver uma motricidade específica.

Pontualmente para crianças que apresentam atrasos no seu desenvolvimento neuropsicomotor, decorrentes ou não de alguma patologia de base, as aulas de circo adaptado constituem, não somente, a possibilidade de estar inserido numa atividade artística, cultural e educativa, numa relação de convivência com seus pares, bem como possibilita mais um momento de estímulo às habilidades que, muitas vezes, se encontram em defasagem nessa população, como por exemplo, a integração das vias sensoriais, o desenvolvimento motor e a capacidade de manter atenção e permanência em tarefas do cotidiano.

A partir da prática das diferentes modalidades circenses, as crianças com deficiência, transtornos ou outros distúrbios do desenvolvimento, têm a oportunidade de explorar diferentes posições do corpo no espaço, realizar alongamentos, exercer força muscular, obter diferentes sensações táteis e proprioceptivas, a partir da exploração de tarefas motoras adaptadas às suas necessidades e à sua forma de se relacionar com o mundo com seu próprio corpo, característica que, segundo Seibel (2005), é um dos elementos mais presentes na prática circense.

Aqui é válido pontuar que, as aulas são consideradas adaptadas, e ainda não inclusivas, devido serem realizadas na maioria das ocasiões como aulas individuais, apesar de partilhar do espaço com outras aulas que ocorrem paralelamente e, também, por não abrangerem todos os níveis socioeconômicos por serem realizadas numa escola de caráter privado, sendo consideradas as possibilidades de ampliação do serviço em caso de recebimento de verba específica para esse fim e, quando possível, na mudança gradual da estrutura organizacional para recebimento dessa população.

\section{CONCLUSÕES}

Vem sendo possível considerar que, o circo adaptado para pessoas com deficiência, é uma ferramenta de desenvolvimento integral, pois, apesar das limitações ainda existentes enquanto possibilidade de inserção direta nos grupos regulares e quanto ao acesso do serviço a populações de diferentes níveis socioeconômicos, a prática dessas atividades começa a trazer para a Casa do Circo alunos que, anteriormente, não realizavam atividade similar e que têm hoje uma vivência de ocupar e compartilhar 
novos espaços, experimentar uma atividade artística e, através do corpo, muitas vezes visto socialmente como limitado ou adoecido, transpor barreiras físicas e atitudinais, externando suas habilidades.

\section{REFERÊNCIAS}

[1] ARAUJO, L.A.D.; FILHO, W.M.C. O Estatuto da Pessoa com Deficiência - EPCD (Lei 13.146, de 06.07.2015): algumas novidades. Revista dos Tribunais Online. Vol 962/2015. p. 65-80. 2015.

[2] BARONI, J. F. Arte circense: a magia e o encantamento dentro e fora das lonas. Revista Pensar a Prática, Goiânia, v.9, n.1, p. 81- 99, jan./jun. 2006.

[3] BORTOLETO, M.A.C.; MACHADO, C.A. Reflexões sobre o Circo e a Educação Física. Revista Corpoconsciência. n.12.p. 39-70. 2003.

[4] Brasil. Ministério da Saúde. Secretaria de Atenção à Saúde. Política Nacional de Saúde da Pessoa Portadora de Deficiência / Ministério da Saúde, Secretaria de Atenção à Saúde - Brasília: Editora do Ministério da Saúde, p. 72. 2008.

[5] MAZZOTTA, M.J.S.; D’ANTINO, M.E.F. Inclusão Social de Pessoas com Deficiências e Necessidades Especiais: cultura, educação e lazer. Revista Saúde Soc. São Paulo. vol.20, n.2.p.377-389. 2011.

[6] POKER, R. B. Fundamentos e estratégias pedagógicas inclusivas: respostas às diferenças na escola. Educar em Revista, Curitiba, Brasil, n. especial 3, p. 193-197, dez. 2017.

[7] SEIBEL, B. Historia Del Circo. Ed. Del Sol. 1aㅡ ed. Buenos Aires, 2005. 


\section{Capítulo 5}

Possibilidades e limites dos alunos com deficiência nas aulas de educação física: Um relato de experiência ${ }^{6}$

Antonio Jansen Fernandes da Silva

Alex de Freitas Pinto

Bryan Kenneth Marques Pereira

Patrícia Mozart Moura

Maria Aparecida Dias

Resumo: Atualmente a Educação inclusiva lida constantemente com debates sobre questões políticas, pedagógicas e sociais. 0 objetivo deste trabalho é relatar as possibilidades e limites da inclusão dos alunos com deficiência nas aulas de Educação Física. Utilizou a pesquisa qualitativa em relato de experiências, com 16 alunos da disciplina "Esportes Adaptados" do PROEF. A deficiência não pode ser o limitador da participação, mas o fio condutor para a compreensão de que a diferença é algo presente no ambiente social.

Palavras-Chave: Educação Física; Inclusão; Alunos com deficiência. 


\section{INTRODUÇÃO}

A inclusão dos alunos com deficiência no ensino regular no Brasil ainda é um dos grandes desafios para educação no século XXI, independente de qual área de conhecimento esteja em debate. A legislação vigente brasileira (Constituição Federal de 1988 e as Leis de Diretrizes e Bases da Educação Nacional no 9394/96) estabelece que a educação é direito de todos e que as pessoas com deficiência devem ser atendidas preferencialmente na rede regular de ensino (BRASIL, 1996).

Considera-se pessoa com deficiência aquela que tem "impedimentos de longo prazo, de natureza física, mental ou sensorial que, em interação com diversas barreiras, pode ter restringida sua participação plena e efetiva na escola e na sociedade" (BRASIL, 2007. p. 9).

A inclusão social é um processo bilateral no qual parte da concepção de identidade e diferença dos sujeitos. Para Woodward (2000, p. 9) "a identidade é, assim, marcada pela diferença". A identidade dos indivíduos é construção coletiva resultante do processo de socialização, pois depende da identidade do outro para se constituir. Como por exemplo: quando digo que "sou professor de educação física", logo "não sou professor de português, matemática e etc.". As afirmações de identidades geram declarações negativas sobre outras identidades. Sendo assim, a identidade depende da diferença, a diferença depende da identidade. Identidade e diferença são, pois, inseparáveis.

Atualmente a Educação inclusiva lida constantemente com grandes discussões, debates e diálogos sobre questões políticas, pedagógicas, metodológicas, curriculares, sociais e dentre outras. A educação física não pode ficar ausente nesse debate, pois como é um componente curricular obrigatório da educação básica, a neutralidade diante deste movimento caracteriza como negligência no ato docente. Observa-se que uma das principais barreiras enfrentadas pelos alunos com deficiência são as atitudinais, ocasionadas por algumas pessoas da comunidade escolar (professores, coordenadores, diretores, funcionários, pais, alunos e dentre outros).

Dessa forma, a intenção deste estudo é relatar as experiências frente às possibilidades e limites da inclusão dos alunos com deficiência nas aulas de Educação Física.

\section{METODOLOGIA}

Baseado na proposta deste estudo, utilizamos a metodologia da pesquisa qualitativa de cunho descritivo no formato de relato de experiências. O cenário da pesquisa foi a Universidade Federal do Rio Grande do Norte (UFRN), no programa de pós-graduação em Educação Física do mestrado profissional em rede nacional (PROEF). A população foi composta por 16 alunos (12 homens e 04 mulheres) na disciplina eletiva do polo de Natal do PROEF intitulada de "Ensino dos Esportes Adaptados", realizada entre os dias 29/01 a 01/02/19, com carga horária de 30 horas. A amostra foi 04 alunos que fizeram parte de uma das equipes da turma que durante a disciplina discutiram, problematizaram e vivenciaram corporalmente conteúdos sobre a temática. Utilizou-se como instrumento de coleta dados a observação participante.

Os dados foram analisados em forma da categorização dos conteúdos. A categorização da experiência pedagógica foi organizada da seguinte forma: 1-aproximação com os textos sobre a história do corpo e as relações sociais das pessoas com e sem deficiência; 2- vivências de práticas corporais inclusivas nas aulas de educação física.

\section{RESULTADOS E INTERPRETAÇÕES}

Na primeira aula foram discutidos quatro textos, a saber: 1- História do corpo: as mutações do olhar (CORBIN et al., 2008); 2- As relações sociais entre pessoas com e sem deficiência (CURTÚ, 2013); 3- A pessoa com deficiência e a crise das identidades na contemporaneidade (MAGALHÃES \& CARDOSO, 2010); 4- Educação motora para deficiente (LOPES \& DIAS, 2012).

Diante do debate gerado em sala, nota-se que os alunos com deficiência são matriculados na rede regular de ensino com um propósito, oportunizar que eles sejam efetivamente incluídos na sociedade desde sua formação educacional inicial. No entanto, para que isso ocorra, faz-se necessário um esforço conjunto de todos os atores envolvidos nesse processo (pais, professores, alunos e sociedade em geral), visando fazer com que estes alunos se sintam acolhidos e capazes de realizar grandes feitos, desenvolvendo assim seu potencial. 
A grande maioria das instituições de ensino superior geralmente ofertam uma ou duas disciplinas aos futuros professores, que não dão conta de abordar uma enorme gama de deficiências e seus aspectos fisiológicos, comportamentais e sociais. Fato constatado na nossa formação inicial enquanto professores de educação física, que não nos deu subsídios (teóricos/práticos) para realizar a verdadeira inclusão.

0 professor com déficit formativo pode escolher três caminhos, dedica-se a estudar mais sobre o assunto, simplesmente promove seu aluno a um auxiliar ou o dispensa na arquibancada, excluindo-o das aulas de educação física.

Temos percebido que os alunos com deficiência mantêm grandes expectativas para com as aulas de educação física, pois os mesmos também são crianças e querem mover seus corpos, dentro, é claro, de suas limitações. Nesse sentido, o professor deve sempre estimular/conscientizar sobre a importância da participação destes na rotina escolar, mesmo muitas vezes tendo que enfrentar barreiras arquitetônicas, corpo docente da escola e a própria família que tende a ter uma relação superprotetora com estes alunos.

Outra barreira a ser transposta é a do próprio aluno, que não se enxerga capaz de realizar certas atividades, ou que sente medo de tentar e fracassar. Pensar em maneiras de transpor tais barreiras atitudinais é um dos caminhos primordiais para a inclusão.

A vivência proporcionada nesta disciplina veio novamente nos explicitar que muito ainda temos que estudar e incentivar a inclusão em nossas aulas. A professora da disciplina sugeriu uma metodologia onde cada equipe teria que preparar uma aula que incluísse alunos com deficiências. Após o sorteio dos temas nossa equipe ficou com os esportes de rede/parede, onde a turma tinha 02 alunos amputados (01 com amputação do braço direito e 01 da perna esquerda).

Aparentemente seria uma tarefa bem simples, visto que todos os integrantes do grupo já possuíam uma certa experiência docente, no entanto tal expectativa foi rapidamente diluída e nos deparamos com sérias dificuldades na escolha de atividades que pudessem ser realizadas pelo público proposto, pois encontrávamo-nos em um dilema: como adaptar as atividades para fazer com que os alunos deficientes possam participar e ao mesmo tempo tal atividade não seja desinteressante para os demais alunos?

Escolhemos o jogo da peteca. Foi proposto que os alunos confeccionassem suas próprias petecas com jornais velhos e fita gomada, visando tornar a aprendizagem mais significativa. Durante o processo de construção do brinquedo percebemos que o aluno com deficiência física (amputado do braço) teve ajuda de outro aluno para criação da sua peteca, que prontamente se disponibilizou à ajudá-lo sem intervenção do grupo.

Após a confecção, foi iniciada a atividade para a familiarização com o material. Como forma de aquecimento foi solicitado que os alunos rebatessem a peteca para cima sem deixá-la cair no chão livremente, e posteriormente, foi realizada a vivência do jogo - primeiramente de forma adaptada (jogadores sentados), visando incluir o aluno deficiente (amputado da perna) e conscientizar os demais alunos sobre as dificuldades e novas habilidades requisitadas. $\mathrm{Na}$ atividade seguinte, com os jogadores de pé, disponibilizamos várias possibilidades de adaptação visando a participação do mesmo aluno, tais como, utilizar cadeiras de rodas, limitando os espaços de locomoção dos jogadores para que o aluno continuasse jogando sentado ou com auxílio de muleta ou do par tutor, a escolha ficou sempre a critério do aluno.

A escolha da peteca para esta aula deu-se por dois motivos, pela motivação proporcionada por esta atividade e por servir de resgate de um jogo popular brasileiro e que vem perdendo espaço em função dos jogos eletrônicos. Após todos os desafios enfrentados coube-nos a reflexão de que precisamos ampliar o conhecimento acadêmico em diálogo com o social, e que devemos lutar pelo maior enfoque do tema na formação inicial.

0 professor que não entende o potencial e limite do aluno pode gerar graves lesões e sequelas. Além de nos policiarmos para que durante as aulas os alunos não sejam submetidos a situações constrangedoras, devemos intervir em atitudes desrespeitosas ou preconceituosas por parte de outros alunos, coibindo assim o bullying. Pois se assim não agirmos, ao invés de incluir estamos excluindo, não só os alunos com deficiência, mas todo nosso alunado. 0 professor que trabalha numa perspectiva inclusiva precisa se qualificar, ser paciente, observar bem seus alunos e ter criatividade. 


\section{CONSIDERAÇÕES FINAIS}

Nota-se que no decorrer do estudo são apontadas algumas possibilidades que podem ser desenvolvidas nas aulas de educação física de forma inclusiva (não só nesta), dentre elas: planejar as aulas respeitando a diversidade dos alunos, seja com ou sem deficiência; propiciar vivências da cultura corporal para todos e respeitar a singularidade dos alunos no processo de ensino-aprendizagem.

Considera-se que alguns limites ainda precisam ser superados diante da educação física inclusiva, dentre eles: a estigmatização das pessoas com deficiência enquanto seres incapazes, inúteis e coitadinhos, disseminada pelas culturas excludentes; o aumento da discussão e pesquisas no campo da Deficiência Intelectual e do Transtorno do Espectro Autismo.

Sugeri-se que profissionais da educação física não sejam inclusivos só no discurso, mas em atitudes frente às pessoas com deficiência que podem fazer grande diferença na vida de outras pessoas como na sua também. Aliás, o fato de ser um humano, já possibilita ter o mesmo direito a usufruir o que a vida lhe oferece. Sabemos que a efetivação desse direito é uma tarefa árdua e cheia de conflitos, mais atitudes reflexivas podem ajudar a entender que da mesma forma que um atleta tem o direito de participar das aulas, os alunos com deficiência, também o tem. A deficiência não pode ser o limitador da participação, mas o fio condutor para abrir a compreensão de que a diferença é algo presente no ambiente escolar e/ou social.

\section{REFERENCIAS}

[1] CORBIN, A et al. A história do corpo: as mutações do olhar. Petrópolis, RJ: Vozes, 2008.

[2] CURTÚ, A. M. B. Relações sociais entre pessoas com e sem deficiência: contribuições da filosofia contemporânea na apreensão de sentidos possíveis. Anais do I Simpósio Internacional de Estudos sobre a Deficiência. São Paulo, junho/2013.

[3] LOPES, K. A; DIAS, M. A. Educação motora para deficiente, 2012.

[4] MAgAlhães, R. C. B. P; CARDoSo, A. P. L. B. A pessoa com deficiência e a crise das identidades na contemporaneidade. Cadernos de Pesquisa, v. 40, n. 139, p.45-61, jan./abr. 2010.

[5] WOODWARD, K. Identidade e diferença: uma introdução teórica e conceitual. In: SILVA, T. T. (org.). Identidade e diferença: a perspectiva dos estudos culturais. Petrópolis: Vozes, 2000. p. 07-72. 


\section{Capítulo 6}

Concepção dos bolsistas sobre um projeto de ensino em Educação Física com o público alvo da Educação Especial

\section{Solange Rodovalho Lima \\ Juliana Cristina Silva \\ Leandro Rezende}

Resumo: 0 estudo analisou a concepção de graduandos/as em Educação Física da Universidade Federal de Uberlândia, sobre sua participação num projeto de ensino de graduação que coloca o/a discente em contato com a realidade da inclusão escolar na Educação Física na Educação Básica. Participaram sete ex-bolsistas do projeto, respondendo à entrevista semiestruturada. Os relatos mostram que o projeto contribuiu para a formação inicial para atuar na inclusão escolar.

Palavras-chave: formação inicial; Inclusão escolar; educação física escolar 


\section{INTRODUÇÃO}

A inclusão escolar tem exigido que, cada vez mais, as instituições escolares estejam preparadas para oferecerem uma escolarização de qualidade para todos seus estudantes. Nesse contexto, torna-se muito relevante a capacitação dos professores, desde sua formação inicial destaca-se o papel das universidades na formação dos professores para atuarem na inclusão escolar.

De acordo com a Declaração de Salamanca (1994) a preparação apropriada de todos os educadores constitui-se um fator chave na promoção de progresso no sentido do estabelecimento de escolas inclusivas (DECLARAÇÃO DE SALAMANCA, 1994).

Participar de um processo inclusivo é estar predisposto a considerar e a respeitar as diferenças individuais, criando a possibilidade de aprender sobre si mesmo e sobre cada um dos outros em uma situação de diversidade de ideias, sentimentos e ações (LIMA, 2009).

A Política nacional de educação especial na perspectiva da educação inclusiva objetiva assegurar a inclusão escolar dos alunos público alvo da educação especial (PAEE), garantindo o acesso ao ensino regular, com participação aprendizagem e continuidade nos níveis mais elevados do ensino, oferta do atendimento educacional especializado. (BRASIL, 2008) Além disso, preconiza a formação de professores para o atendimento educacional especializado (AEE) e os demais profissionais da educação para a inclusão escolar.

Nesse processo de formação, cabe destacar o papel das instituições e o reconhecimento das instituições de educação básica como espaços necessários à formação desses profissionais. Com este compromisso, a área de Educação Física do Colégio de Aplicação (CAp) da Universidade Federal Uberlândia (UFU), em parceria com o curso de Graduação em Educação Física, com o apoio da Pró-Reitoria de Graduação (PROGRAD), desenvolve desde 2013, um projeto com o intuito de complementar a formação inicial dos/ as acadêmicos/as, para atuarem com o PAEE na educação básica, bem como colaborar com os professores em exercício, para que haja a efetiva do/a aluno/a nas aulas. No projeto que teve início em 2013 e é anual os/as acadêmicos/as participam como bolsistas.

No projeto os/as bolsistas, acompanham as aulas de Educação Física do CAp/UFU, nas turmas com alunos/as PAEE. Suas principais funções compreendem: elaborar registros descritivos das habilidades sociais, motoras, cognitivas e comunicativas dos/das alunos/as, da organização do ambiente da aula e do ambiente do recreio; das ações pedagógicas dos professores, que favorecem ou não, a inclusão do aluno, bem como as atividades mais motivadoras para os mesmos durante as aulas. Tais registros contribuem para minimizar as dificuldades encontradas pelos/as professores/as de Educação Física do CAp, pois tornam possível à análise e discussão das ações do ensino-aprendizagem e estratégias que favoreçam o processo de inclusão escolar.

Diante disso, este estudo analisou a concepção de graduandos/as em Educação Física da Universidade Federal de Uberlândia, sobre sua participação num projeto de ensino de graduação. Especificamente os objetivos foram: Identificar as principais contribuições do projeto para a formação inicial dos/as acadêmicos/as; avaliar quais os saberes adquiridos pelos/as acadêmicos/as durante projeto; verificar as principais dificuldades dos/as acadêmicos/as nas experiências de ensino vivenciadas junto aos/as alunos/as com deficiência; verificar se os/as acadêmicos/as consideram-se preparados/as para trabalhar com alunos deficiência na Educação Básica.

\section{PROCEDIMENTOS METODOLÓGICOS}

O estudo caracteriza-se como de campo de caráter descritivo (GIL, 2002). Participaram sete acadêmicos/ as do projeto de acompanhamento de alunos/as PAEE nas aulas de Educação Física no CAp/UFU, entre os anos 2013 e 2016.

Utilizou-se uma entrevista semiestruturada. Com autorização dos participantes, os relatos foram gravados em um aplicativo de gravador de áudio e posteriormente foram transcritas na íntegra.

\section{RESULTADOS E DISCUSSÃO}

Na apresentação dos resultados, os/as participantes, foram denominados acadêmicos/as, seguidos do respectivo número, por exemplo, Bolsista 1 (B1). 
Os/as acadêmicos/as relataram dois pontos comuns sobre as contribuições do projeto para a formação inicial: antes do projeto não tinham vivenciado experiências com crianças PAEE na escola regular e que com o projeto aprenderam a lidar com essas crianças nesse ambiente.

0 que contribuiu foi conhecimento particular, eu não tinha vivenciado experiências com crianças com deficiência, nunca tinha trabalhado com criança com deficiência, só com adulto, e isso contribuiu com que pudesse investigar mais e saber lidar melhor com crianças com deficiência na escola (B2).

“... aprender a trabalhar com alunos com deficiência nas aulas. Então acredito que tudo foi válido que toda a experiência que eu vivenciei foi muito válida na minha formação." (B6).

Os/as professores/as encontram algumas dificuldades decorrentes do trabalho feito pela Educação Física ao longo dos anos. Para Carmo (2006) essa área vem trabalhando com a pessoa com deficiência isoladamente e ao se deparar com essa situação no contexto escolar os professores atuam na perspectiva de adaptação do esporte.

Mendes (2015) diz ser necessária uma preparação adequada dos professores para lidar com alunos com deficiência buscando melhorar a qualidade da Educação e criando condições para a inclusão escolar, especialmente na Educação Básica. 0 primeiro passo para isso é os professores aprenderem a lidar com esses/as alunos/as, como apontam os/as acadêmicos/as.

Sobre os saberes adquiridos no projeto, para todos/as, o planejamento de ensino foi o mais relevante. "Eu aprendi muito a montar um planejamento, adaptar uma aula para criança com deficiência. Aprendi a montar meu plano de aula baseado nisso vendo as deficiências dos alunos.” (B2). “... eu aprendi a fazer um planejamento. Aprendi o que era planejamento... o que eram os sequenciadores das aulas" (B3).

O planejamento é indispensável para atingir os objetivos propostos e para que os/as professores/ as controlem e avaliem suas as aulas. Para Almeida (2010) a relação do/a professor/a com o planejamento requer respeito e cuidado, visto sua importância para a prática pedagógica, oferecendo condições de maior aprendizagem para a formação do/a aluno/a. Para os/as acadêmicos/as, foi importante aprender sobre o planejamento e estratégias de ensino no ambiente educacional, pois lhes proporcionou uma pluralidade de interações e percepções junto aos/as alunos/as.

Em relação às principais dificuldades vivenciadas nas experiências de ensino com o PAEE, foram relatados pontos em comuns.

Acho que a inclusão é a maior dificuldade de todas, porque as vezes tinha um aluno cadeirante e é muito difícil planejar uma aula em que ele pudesse participar da mesma forma que todos. Eu acho que aula para eles sempre vai ser diferente. É muito difícil você incluir um aluno com deficiência na aula, acho que essa parte foi a mais difícil. Com relação a dificuldade com o todo, eu acho que é minha maior dificauldade (B1).

“0 mais difícil é incluir o aluno com deficiência nas aulas, porque como docente que eu fui o ano passado é o mais difícil por mais que o princípio da inclusão seja esse é muito difícil você conseguir chegar na real inclusão como eles pregam é muito difícil" (B6).

A inclusão nas aulas de Educação Física, ainda é um desafio. Para Carmo (2001, p. 106) “...enquanto as outras áreas do conhecimento conseguem com pequenos arranjos metodológicos trabalhar com a diversidade humana no mesmo espaço e tempo, a Educação Física somente tem conseguido este feito em espaços e tempos diferentes.

Este fato evidencia-se na fala de um dos bolsistas quando afirma “... porque às vezes tinha um aluno cadeirante e é muito difícil planejar uma aula em que ele pudesse participar da mesma forma que todos"(B1) 
Assim, não basta apenas adaptações de materiais, regras e espaço, pois suas necessidades são diferentes e alunos com deficiência necessitam de outra forma de organização das aulas que contemple seu tempo de aprender e suas dificuldades. A inclusão é um processo em construção e para que aconteça são necessários mais estudos, análises, discussões, problematizações sobre o que nos incomoda e porque nos incomoda.

Sobre a preparação no projeto para trabalhar com alunos com o PAEE os/as acadêmicos/as, apontaram um ponto em comum, isto é o fato de se sentirem de certa forma, preparados para trabalharem com o PAEE no ambiente escolar.

Me sinto um pouco preparada, mas a gente tem que ver também que a Eseba oferece todo um suporte para a gente trabalhar com essa criança. Tem os monitores e tudo que ajuda muito. Hoje eu trabalharia em uma escola, não teria tanta dificuldade. Acho que na Eseba dá para trabalhar melhor por causa dos monitores (B1).

Para Lima (2002) a maioria dos futuros/as professores/as, sentem-se inseguros/as diante da probabilidade de ter uma criança com deficiência na sala de aula regular. A formação dos professores requer atenção quando se aborda inclusão. Segundo Rodrigues (2006) ela tem sido uma dificuldade para atender aos princípios da inclusão escolar, pois poucos currículos de cursos de graduação em Educação Física possuem disciplinas voltadas para a Educação Especial.

\section{CONSIDERAÇÕES FINAIS}

De acordo com a concepção dos/das acadêmicos/as, a maior dificuldade foi incluir o o PAEE nas aulas de Educação Física, pois em muitos momentos são desenvolvidas as mesmas atividades, no mesmo espaço e tempo.

A inclusão é um processo em construção, o qual encontra inúmeros desafios. Assim, importa aproximarse, cada dia mais, dos objetivos da inclusão no sentido de se trabalhar com o PAEE e seus pares o público não alvo da educação especial, em uma mesma turma.

Os/as ex-bolsistas sentem-se preparados, pois dedicaram e participaram das atividades propostas no projeto e assim obtiveram conhecimentos importantes para a formação docente.

\section{REFERÊNCIAS}

[1] BRASIL. Ministério da Educação. Secretaria de Educação Especial. Política nacional de educação especial na perspectiva da educação inclusiva. Brasília, 2008. Disponível em: http://peei.mec.gov.br/arquivos/politica_nacional_educacao_especial.pdf. Acesso em: 20 de set. 2016.

[2] CARMO, A. A. Atividade motora adaptada e inclusão escolar: caminhos que não se cruzam. In: RODRIGUES, D. Atividade motora adaptada: a alegria do corpo. São Paulo: Artes Médicas, 2006.

[3] GIL, A. C., Métodos e técnicas de pesquisa social. 5. ed. São Paulo: Atlas, 2002

[4] LIMA, P. A. Educação Inclusiva e igualdade social. Editora AVERCAMP, São Paulo, 2002.

[5] LIMA, S. R. Escolarização da pessoa com deficiência intelectual: terminalidade específica e expectativas familiares. 2009. 179 f. Tese (Doutorado em Educação Especial) - Faculdade de Educação Física, Universidade Federal de São Carlos, São Carlos, 2009.

[6] MENDES, J. A. C. Impactos da inclusão escolar nas aulas de educação física infantil: o caso da Eseba/UFU. 2015.19 f.

[7] Trabalho de conclusão de curso. Curso Graduação em Educação Física. Uberlândia: 2015.

[8] RODRIGUES, D. As promessas e as realidades da inclusão de alunos com necessidades especiais nas aulas de Educação Física. In: Atividade motora adaptada: a alegria do corpo. São Paulo: Artes Médicas, 2006. 


\section{Capítulo 7}

\section{Educação Física e Atendimento Educacional Especializado: Ampliando possibilidades na EJA}

\section{Marcela Fontão Nogueira \\ Adriana Della Gatta Soares}

Resumo: Este relato foi apresentado no VIII Congresso Brasileiro de Educação Especial e refere-se ao projeto de ampliação de jornada dos estudantes público da educação especial em um Centro Integrado de Educação de Jovens e Adultos (CIEJA) no município de São Paulo, através da parceria entre o Atendimento Educacional Especializado e a disciplina Educação Física. 0 objetivo desse trabalho foi problematizar as possibilidades de atendimento ao estudante adulto com deficiência, a partir dos eixos temáticos Lutas, Danças e Jogos/brincadeiras previstos no Currículo da Cidade para Educação Física. Com base no conceito de enriquecimento curricular e a utilização de diferentes estratégias de intervenção pedagógica, os estudantes com deficiência do CIEJA Perus I frequentaram oficinas de artes marciais, expressão corporal e jogos virtuais com duração de 3 horas/aula, três vezes por semana entre os meses de abril e julho de 2018. De acordo com o relatório individual das professoras da sala de recursos multifuncionais e apontamentos do grupo de professores de sala regular, podemos concluir que ao final do semestre os estudantes apresentaram melhoras significativas nos aspectos físicos, cognitivos e sociais.

Palavras chave: Educação de Jovens e Adultos, Educação Física, Educação Especial 


\section{INTRODUÇÃO}

0 processo histórico da Educação de Jovens e Adultos (EJA) no contexto brasileiro é amplamente discutido por autores como Haddad e Di Pierro (2000), Beisiegel (2003), Galvão e Di Pierro (2013). Os direitos educativos de jovens e adultos que não completaram a escolarização básica estão promulgados na Constituição Federal de 1988 em seu Art. 208, que assegura a oferta da educação básica gratuita para todos os que a ela não tiveram acesso na idade própria, assim como na Seção V do Capítulo II da Lei de Diretrizes e Bases da Educação Nacional 9394/96, destinada a discutir a Educação de Jovens e Adultos em seus artigos 37 e 38 .

Documentos Internacionais como a Declaração Mundial sobre Educação para Todos em Jomtien (1990), a Declaração de Hamburgo sobre a Educação de Adultos (1997) e a Conferência Internacional de Jovens e Adultos (CONFINTEA) são importantes marcos para a discussão e garantia de direitos e o acesso à educação para essa população.

Ainda que as discussões tenham avançado internacionalmente e influenciado a política educacional, milhares cidadãos brasileiros permanecem fora do sistema educacional. Segundo dados da Pesquisa Nacional por Amostra de Domicílio (PNAD) de 2018, divulgada em junho de 2019 pelo Instituto Brasileiro de Geografia e Estatística (IBGE), o Brasil possui 11,3 milhões de analfabetos (6,8\% da população) e 34\% da população não tem o ensino fundamental completo.

A resolução CNE/CEB no 1, de 5 de julho de 2000 que estabelece as Diretrizes Curriculares Nacionais para a Educação de Jovens e Adultos aponta que a EJA representa uma dívida social não reparada para com os que não tiveram acesso e nem domínio da escrita e leitura como bens sociais e que ser privado deste acesso é a perda de um instrumento imprescindível para uma presença significativa na convivência social contemporânea.

Para atender a demanda específica do município de São Paulo, a Secretaria Municipal de Educação (SME) oferta cinco formatos de Educação de Jovens e Adultos. O Centro Integrado de Educação de Jovens e Adultos (CIEJA) é um projeto educacional regulamentado pela Lei Municipal 15.648 de 14 de novembro de 2012 e suas normas de funcionamento são estabelecidas pela Portaria 9.032, de 04 de dezembro de 2017. Segundo Di Pierro (2017) o atendimento desenvolvido no CIEJA se configura como forma de atendimento adequada ao público demandante. Sua principal característica é a flexibilidade de horários, já que oferece aulas pela manhã, tarde e noite, em 6 turnos diferentes e com duração de duas horas e quinze minutos.

... escolas organizadas exclusivamente para atender jovens e adultos reúnem melhores condições para flexibilizar os tempos e espaços de ensino e aprendizagem com vistas a torná-las mais atrativas e adequadas ao público a que se destinam. A possibilidade de matrícula a qualquer momento do ano, a oferta de jornadas escolares relativamente curtas e múltiplos horários de estudo, a existência de assistência estudantil, o recrutamento seletivo, o trabalho coletivo e a dedicação intensiva dos docentes parecem favorecer esse resultado (DI PIERRO, 2017, p. 104).

O estudante jovem e adulto que não concluiu a educação básica no tempo previsto carrega consigo o peso da bagagem da exclusão, o que nos remete a importância de uma escola libertadora e de uma educação emancipatória como defendia Freire (2007). Justamente por flexibilizar tempos, espaços e repensar a maneira de construção do conhecimento, é que o projeto CIEJA representa desde a sua criação em meados dos anos 2000, um foco de resistência que dá voz e vez a uma imensa parcela da população excluída do sistema educacional, composta por jovens, adultos, idosos e pessoas com deficiência.

Nogueira, Alves e Campos (2021, p. 5) apresentam descrição detalhada do funcionamento do CIEJA Perus I, local em que este relato de experiência se desenvolveu. As autoras discutem, a partir do Projeto Político Pedagógico da Escola, sua organização pedagógica com relação aos tempos e espaços escolares. Uma das 16 unidades do projeto, o CIEJA Perus I está localizado na região noroeste do município e foi inaugurado em fevereiro de 2016. Referência no atendimento a estudantes migrantes, em especial da comunidade haitiana, a escola possui atualmente 1.257 estudantes matriculados, dos quais 39 são estudantes com deficiência, números muito próximos aos do ano de 2018, momento em que se desenvolveu essa experiência . 
Com relação ao estudante jovem e adulto com deficiência propriamente dito, os CIEJAs recebem grande parte das matrículas desses estudantes. Em função da ampla oferta de horário e tempo reduzido de permanência na escola, Atendimento Educacional Especializado (AEE) e transporte escolar gratuito para esse público, sua presença tem aumentado consideravelmente (Nogueira, 2020).

Glat e Antunes (2012) afirmam que o sujeito da educação, numa visão contemporânea, deve ser dotado de pensamento e linguagem inteligíveis, sendo os alunos com algum tipo de deficiência excluídos da escolarização formal por não atenderem a esses critérios, levando muitas vezes a interrupção da trajetória escolar pelo preconceito gerado a partir de uma visão homogênea de sociedade. De acordo com Siems (2011) a chegada desses alunos tem ocorrido de maneira mais acentuada nos últimos anos em consequência da ampliação do acesso desses estudantes ao ensino regular. Para Hass (2015, p. 348) "o espaço escolar pode constituir-se como lugar potente e legítimo" de atendimento a esse público, proporcionando desenvolvimento humano e social às pessoas com deficiência.

A Lei Brasileira de Inclusão da Pessoa com Deficiência em seu artigo 28, incumbe ao poder público assegurar um sistema educacional inclusivo em todos os níveis e modalidades, bem como o aprendizado ao longo de toda a vida Assim, o objetivo desse relato de experiência é problematizar as possibilidades de atendimento ao estudante adulto com deficiência, em projetos envolvendo a Educação Física e o AEE, a partir dos eixos temáticos Lutas, Danças e Jogos/brincadeiras previstos no Currículo da Cidade para Educação Física.

Sua justificativa se deu em função do grande número de estudantes público da educação especial e da necessidade de estruturarmos a ampliação da jornada de maneira a atender o maior número possível de estudantes.

\section{DESENVOLVIMENTO}

Enquanto componente curricular obrigatório da Educação Básica e de acordo com o Currículo da Cidade de São Paulo (2017), a Educação Física pertence a área de linguagens e possui como eixos temáticos da cultura corporal Jogos/Brincadeira, Lutas, Esportes, Danças, Ginásticas e Práticas Corporais de Aventura. Em alguns casos específicos na educação de jovens e adultos, sua obrigatoriedade deixa de existir e a oferta das aulas está condicionada a abertura de turmas no contraturno escolar. Dessa maneira, as aulas de Educação Física no CIEJA Perus I ocorrem por meio de projetos ou oficinas, abertas a todos os estudantes, tendo como principal característica a flexibilização de tempos e espaços.

O currículo da cidade prevê ainda em seus princípios norteadores, uma educação integral, equânime e inclusiva, o que possibilitou a idealização de um projeto de parceria entre o AEE e a Educação Física na unidade escolar.

Pensando a Educação Física na área da linguagem como preconizado pelos documentos legais, os estudos das altas habilidades/superdotação vieram ao encontro da proposta do projeto e tornaram-se o referencial do estudo. As teorias de Joseph Renzulli (2004) e seus modelos de identificação e atendimento a estudantes superdotados e talentosos tem sido amplamente discutidos por estudiosos e pesquisadores das Altas Habilidades /Superdotação enquanto segmento da Educação Especial no mundo inteiro. No Brasil, o Ministério da Educação (MEC), adota a nomenclatura altas habilidades/superdotação como sinônimos, mas outras nomenclaturas coexistem no território brasileiro e, conforme Fleith e Alencar (2007) "o termo altas habilidades" dá maior ênfase ao desempenho do que às características da pessoa, enquanto o termo "superdotado" sugere habilidades extremas (ALENCAR, 2001; ALENCAR E FLEITH, 2001; VIRGOLIM, 1997). A Política Nacional de Educação Especial na Perspectiva da Educação Inclusiva, de janeiro de 2008, define alunos com altas habilidades/superdotação como:

Alunos que demonstram potencial elevado em qualquer uma das seguintes áreas, isoladas ou combinadas: intelectual, acadêmica, liderança, psicomotricidade e artes. Também apresentam elevada criatividade, grande envolvimento na aprendizagem e realização de tarefas em áreas de seu interesse.

Nesse relato de experiência, a contribuição desse autor não se refere a identificação tardia ou AEE de estudantes alto habilidosos, mas sim à importância da valorização das potencialidades humanas defendida por suas pesquisas, evidenciadas a partir de programas de enriquecimento curricular. Sakaguti, Costa e 
Elias (2015) definem o enriquecimento curricular como uma prática educacional voltada para a promoção de estímulos e experiências investigativas compatíveis aos interesses e habilidades do aluno.

De acordo com as autoras, o enriquecimento curricular representa ainda a aplicação de ações de políticas públicas. Para Virgulim,

As políticas dos sistemas de ensino devem prever a eliminação das barreiras à educação dos alunos com necessidades educacionais especiais, promovendo a participação a partir de novas relações pedagógicas centradas nos modos de aprender das diferentes crianças e jovens, e de relações sociais, que valorizam a diversidade de todas as atividades, espaços e formas de convivência e trabalho. (VIRGOLIM, 2007, P.08)

Vindo ao encontro dessa perspectiva, o projeto de ampliação de jornada pautado em conteúdos da Educação Física, tem proporcionado experiências motoras, cognitivas e principalmente sociais aos estudantes jovens e adultos com deficiência no CIEJA Perus I, oferecendo atendimento educacional especializado com atividades complementares que aprofundam e enriquecem o currículo, ampliando e diversificando os conhecimentos, sem contudo deixar de promover a inclusão educacional e social, estimular o pensamento produtivo e desenvolver potencialidades e habilidades específicas.

As atividades tiveram início no mês de abril de 2018 e ocorrem todas as segundas, quartas, quintas e sextas feiras das $10: 00 \mathrm{~h}$ às $12: 00 \mathrm{~h}$. Os vinte e cinco estudantes participantes do projeto frequentam as aulas regulares das $7: 30 \mathrm{~h}$ às $9: 45 \mathrm{~h}$ ou das $12: 30 \mathrm{~h}$ às $14: 45 \mathrm{~h}$, já que todos estão matriculados na sala regular e participam das atividades com os demais estudantes da escola.

As aulas de artes marciais e expressão corporal ocorriam todas às segundas e quartas. Eram planejadas e ministradas por uma equipe de trabalho, formada pela professora de educação física e sala de recursos multifuncionais, um professor de Muay Thai e uma professora de artes cênicas. Em ambas as práticas, além dos elementos lúdicos, eram trabalhadas sequências de movimentos, que exigiam concentração, memorização, flexibilidade e força, com baixa intensidade visando a estabilidade da frequência cardíaca, como indicam as imagens 1,2 e 3.

Imagem 1 - Sequência de "ataque e defesa"

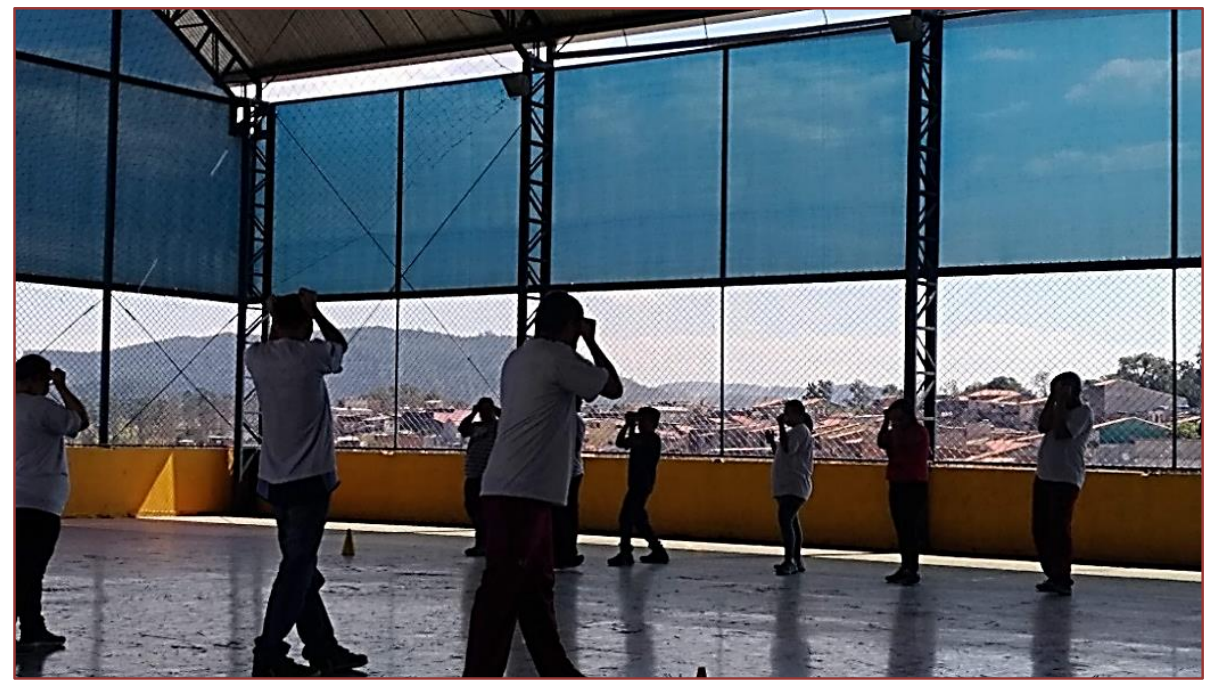

Fonte: arquivo pessoal 
Imagens 2 e 3 - Experimentando as luvas
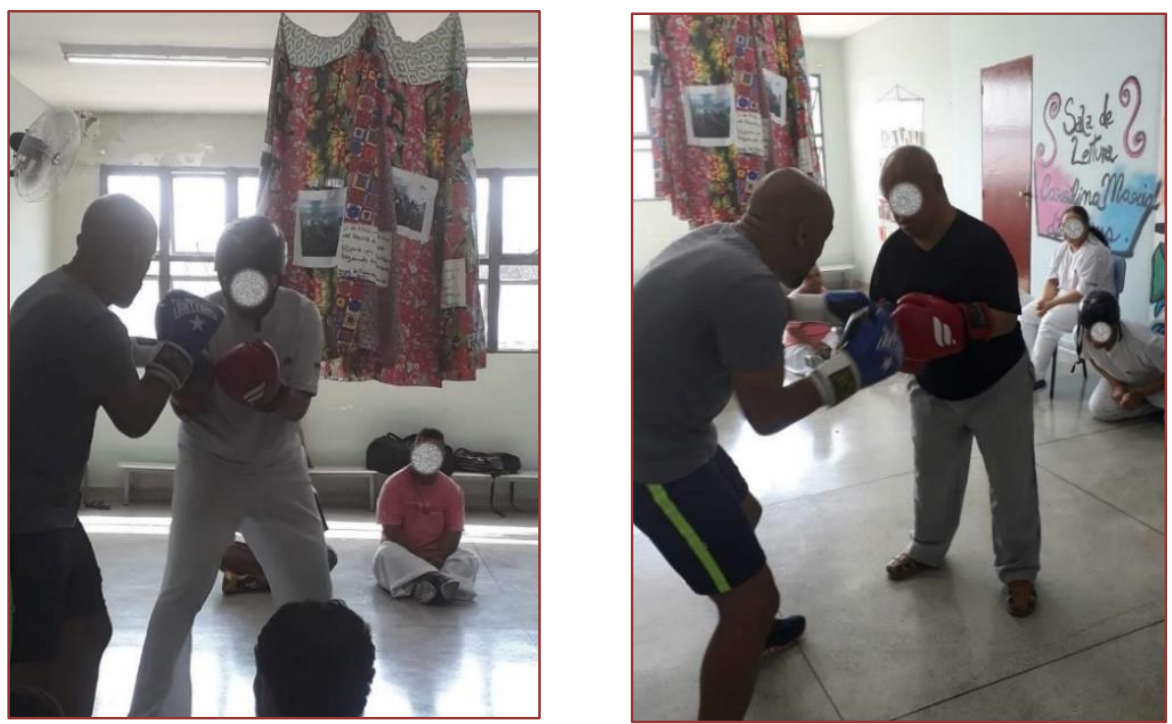

Fonte: arquivo pessoal

Na imagem 1 os estudantes estão na quadra, vivenciando uma sequência de movimentos que envolve o soco "direto" no ar e a volta para a posição de defesa, já nas imagens 2 e 3 os estudantes puderam experimentar os mesmos gestos, agora utilizando as luvas com auxílio do professor.

As imagens 4 e 5 apresentam dois momentos muito importantes dessa atividade: o aquecimento e a roda de conversa final.

Imagem 4 - Aquecimento

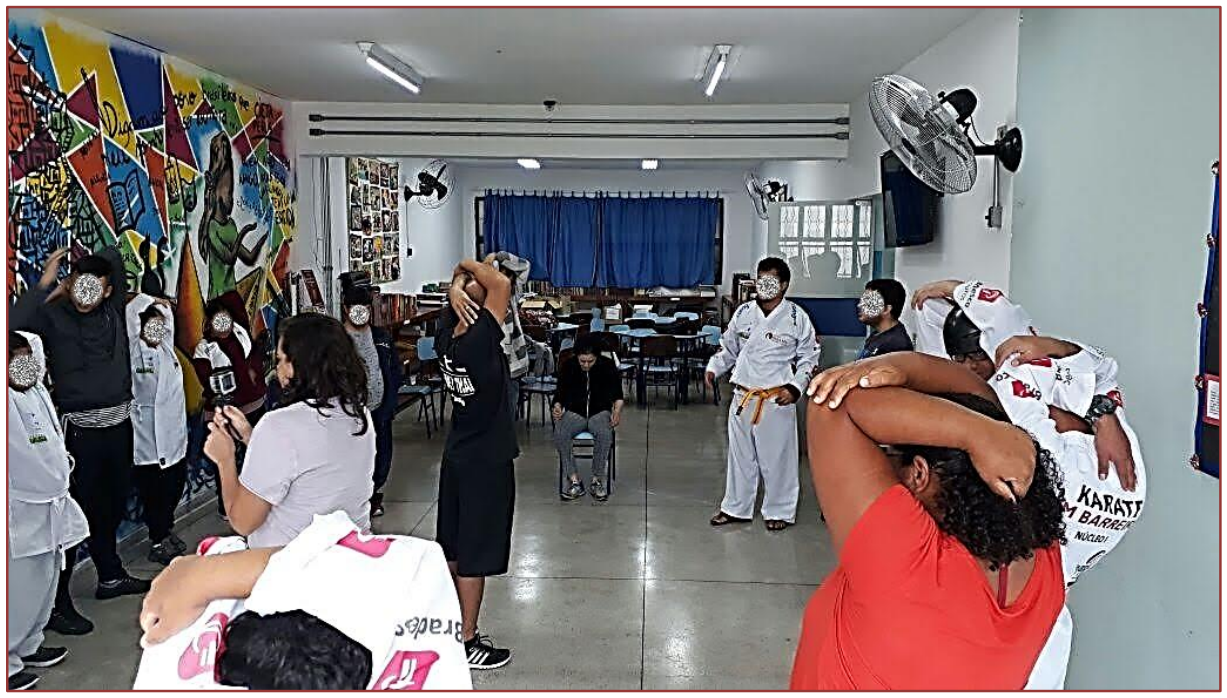

Fonte: arquivo pessoal 
Imagem 5 - Roda de conversa final

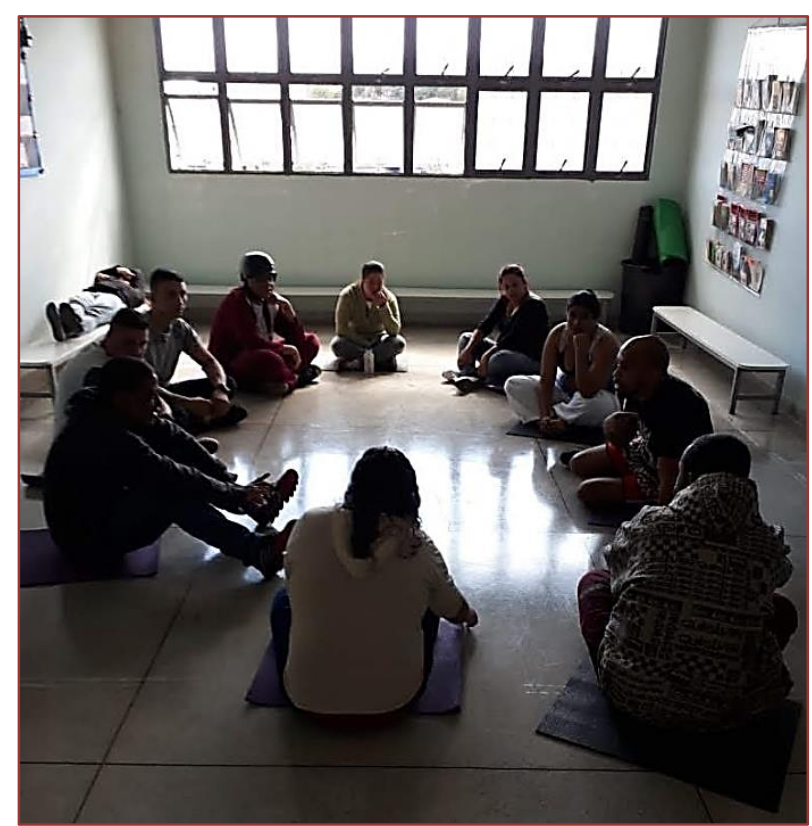

Fonte: arquivo pessoal

Durante o aquecimento eram realizados alguns exercícios de alongamento e rotação das articulações, mas também esse era um momento de muita conversa e descontração, de criação de vínculos entre o grupo. A roda de conversa final, por sua vez, era dedicada à retomada do que havíamos aprendido no dia, assim como à percepção dos estudantes sobre a vivência.

O objetivo das práticas não era a execução perfeita dos gestos motores, pois esses são entendidos como elementos de expressão da cultura corporal. O registro escrito, em vídeo e fotografias serviram como complemento para o processo avaliativo.

A oficina de jogos virtuais acontecia às sextas feiras e era frequentada por estudantes com e sem deficiência. As atividades propostas eram desenvolvidas com um aparelho de vídeo game, ligado a um sensor de movimentos que permitia aos estudantes interagirem com o jogo seja dançando ou praticando esportes de maneira individual, em duplas ou quartetos.

Imagem 6 - Estudantes com e sem deficiência escolhendo o jogo

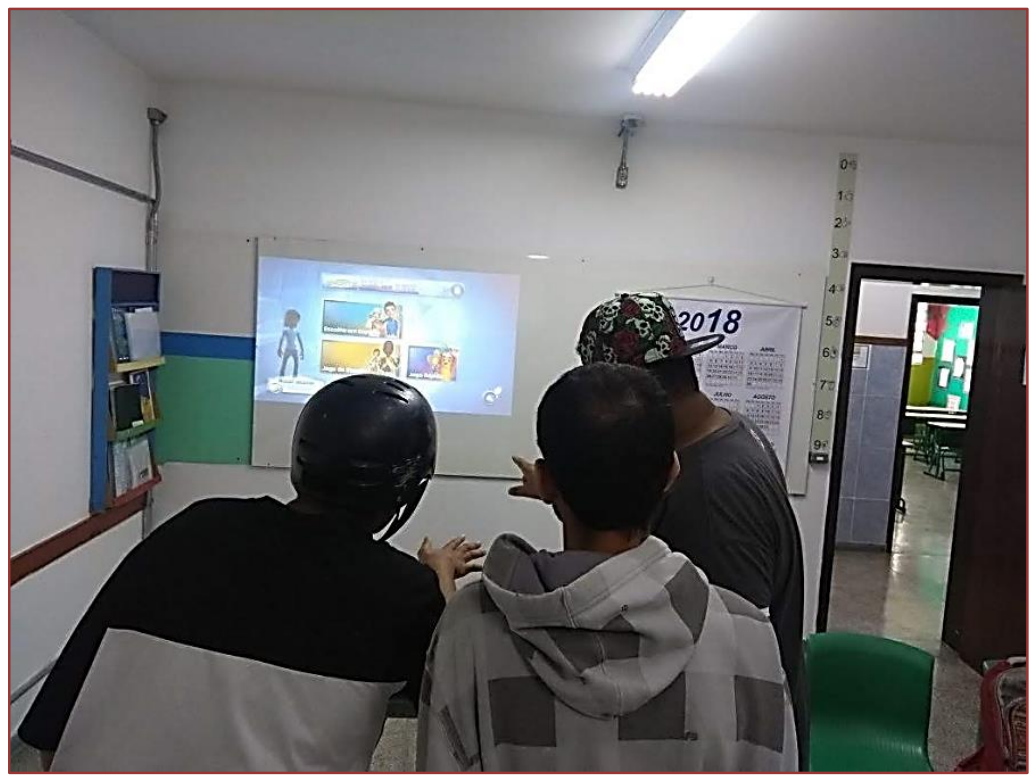

Fonte: arquivo pessoal 
Na imagem 6 temos a interação entre dois estudantes com deficiência e um estudante sem deficiência. A escolha dos jogos exigia argumentação e respeito às possibilidades do outro, com aceitação dos limites e preferências de cada um. Eram momentos de trocas, em que os estudantes desenvolviam muito mais que apenas habilidades no jogo.

Outros jogos esportivos que utilizam o controle e eram jogados em duplas também foram experimentados. Esses eram momentos importantes de discussão sobre as regras dos esportes e diferenças entre o jogo virtual e o real. A imagem 7 apresenta uma partida de futebol.

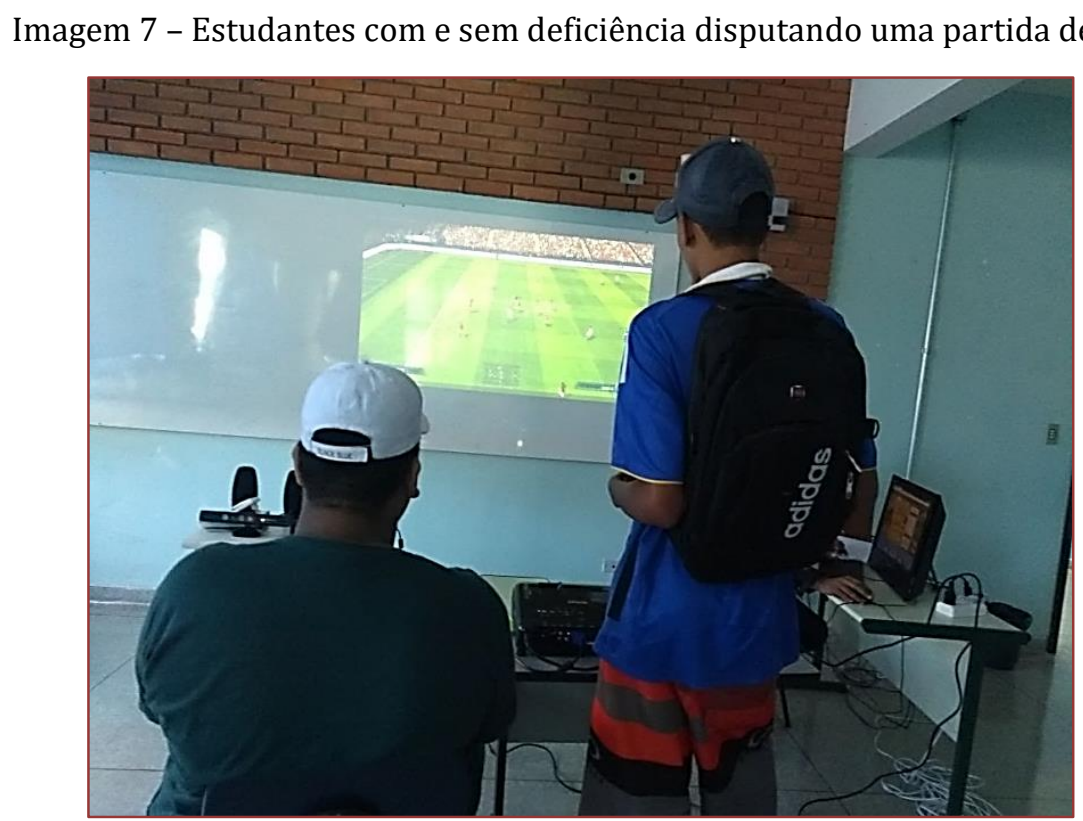

Fonte: arquivo pessoal

Os estudantes eram convidados a participar das aulas e sua frequência era facultativa por se tratar de uma oficina. Percebemos um grande número de estudantes jovens e do sexo masculino por ser tratar de uma atividade que dialogava com seus interesses. No entanto, notamos que aos poucos o espaço passou a ser ocupado também por mulheres, como indicado na imagem 8.

Imagem 8 - Estudantes com e sem deficiência disputando uma partida de tênis

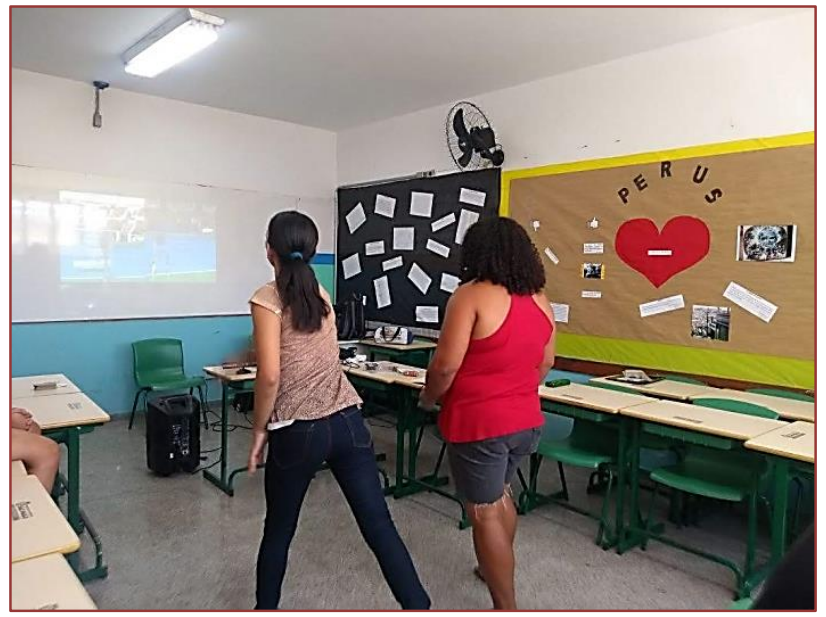

Fonte: arquivo pessoal 
Durante as atividades, pudemos identificar a transferência de aprendizagem como discutido por Moraes (2017), já que os estudantes foram capazes de utilizar os conhecimentos adquiridos nas vivências de artes marciais e expressão corporal durante os jogos virtuais. Além do vídeo game, jogos no computador e nos celulares também são utilizados, pois fazem parte da linguagem virtual adotada como proposta.

Ao final do mês de julho, foram apresentados os relatórios individuais dos estudantes e a equipe docente e gestores da unidade optaram pela manutenção do projeto, já que os estudantes público da educação especial apresentaram melhoras significativas nos aspectos motores, cognitivos e sociais.

\section{BREVES CONSIDERAÇÕES}

O processo de escolarização de jovens e adultos é historicamente marcado pelo estigma do fracasso, onde o estudante ora é julgado socialmente e impedido de acessar o mundo letrado, ora sucumbe ao crivo de seu próprio julgo, assumindo a responsabilidade e a culpa pela não conclusão de seus estudos.

O caráter reparador da EJA no município de São Paulo, representa a possibilidade de estudantes jovens e adultos com deficiência usufruírem seu direito básico à uma educação pública de qualidade, que respeita a diferença e valoriza suas potencialidades. A flexibilização de horários, oferta de transporte escolar gratuito e atendimento educacional especializado garantem o acesso e permanência desses estudantes na escola.

Assim, o projeto de ampliação de jornada e o Atendimento Educacional Especializado em parceria com a disciplina Educação Física proporcionaram o desenvolvimento de diferentes habilidades e a construção do conhecimento ampliando as possibilidades de interação com o meio, com os colegas e com seu próprio corpo.

\section{REFERÊNCIAS}

[1] ALENCAR, E. Criatividade e educação de superdotados. Petrópolis: Vozes, 2001.

[2] ALENCAR, E. S.; FLEITH, D. de S. Superdotados: determinantes, educação e ajustamento. 2. ed. São Paulo: EPU, 2001.

[3] ARROYO, M. Passageiros da Noite: do trabalho para a EJA: itinerários pelo direito a uma vida justa. Petrópolis, RJ: Vozes, 2017

[4] BEISIEGEL, C. A educação de jovens e adultos analfabetos no Brasil. Alfabetização e Cidadania, São Paulo, n.16, p.19-27, jul.2003.

[5] BRASIL. Constituição (1988). Constituição da República Federativa do Brasil: versão atualizada até a Emenda n. 77/2014. Disponível em: http://goo.gl/HwJ1Q. Acesso em: 10 maio 2018.

[6] __ Lei de Diretrizes e Bases (LDB), de 20 de dezembro de 1996. Dispõe sobre as diretrizes e bases da Educação Nacional. Acesso em: maio de 2018.

[7] ___. Lei no 13.146, de 6 de julho de 2015. Institui a Lei Brasileira de Inclusão com Pessoa com Deficiência (Estatuto da Pessoa com Deficiência). Brasília, DF. 2015

[8] __ Ministério da Educação. Secretaria de Educação Especial. Política Nacional de Educação Especial na Perspectiva da Educação Inclusiva. Brasília: MEC, 2008.

[9] _. Documento Nacional Preparatório à VI Conferência Internacional de Educação de Adultos, VI CONFINTEA. Ministério da Educação. Secretaria de Educação Continuada, Alfabetização e Diversidade, 2009.

[10] CIEJA PERUS I. Projeto Político-Pedagógico. São Paulo, 2019.

[11] CONFERÊNCIA Mundial de Educação para Todos. Declaração Mundial de Educação para Todos. Plano de Ação para Satisfazer as Necessidades Básicas de Aprendizagem. Brasília, DF: UNIFEC, 1990.

[12] DECLARAÇÃO DE SALAMANCA: Sobre Princípios, Políticas e Práticas na Área das Necessidades Educativas Especiais, Salamanca-Espanha, 1994. Disponível em:

<http://portal.mec.gov.br/seesp/arquivos/pdf/salamanca.pdf>. Acesso em: 12 maio 2018.

[13] DI PIERRO, M. C. Educ. Soc., Campinas, v. 31, n. 112, p. 939-959, jul.-set. 2010. Disponível em http://www.cedes.unicamp.br

[14] DI PIERRO, M. C. Centros públicos de educação de jovens e adultos no estado de São Paulo. São Paulo: FEUSP, 2017. 
[15] DI PIERRO, M. C.; HADDAD, S. Escolarização de Jovens e Adultos. Revista Brasileira de Educação, n. 14, p. 108-130, mai./jun./jul./ago. 2000. Disponível em: <http://www.scielo.br/pdf/rbedu/n14/n14a07.pdf>. Acesso em: jul. de 2017.

[16] FARIA, V. A trajetória do projeto CIEJA entre as políticas públicas de EJA na cidade de São Paulo / Vanessa Elsas Porfírio de Faria; orientação Maria Clara di Pierro. São Paulo : s.n., 2014.

[17] FREIRE, P. Educação como prática da liberdade. 30. ed. São Paulo: Paz e Terra, 2007.

[18] _ _ Pedagogia do oprimido. 17.ed. Rio de Janeiro: Paz e Terra, 1987.

[19] GLAT, R. \& ANTUNES, K. C. V. Pesquisa em educação especial: reflexões

[20] sobre sujeitos, ética e metodologia. In: TAQUETTE, S. R. \& CALDAS, C. P. (Org.). Ética e pesquisa com populações vulneráveis. Rio de Janeiro: Eduerj, p. 267-292, 2012.

[21] HAAS, C. Educação de jovens e adultos e educação especial: a (re)

[22] invenção da articulação necessária entre as áreas. Educação, Santa Maria, v. 40, n. 2, p. 347-360, maio/ago. 2015.

[23] IBGE - Instituto Brasileiro de Geografia e Estatística. Disponível em: http://www.ibge.gov.br. Acesso em: 28 mai. 2018.

[24] MORAES, Í. A. P. Transferência de aprendizagem motora entre ambientes real e virtual no transtorno do espectro autista. 2017. Dissertação (Mestrado em Atividade Física, Saúde e Lazer) - Escola de Artes, Ciências e Humanidades, Universidade de São Paulo, São Paulo, 2017.

[25] NOGUEIRA, M. F. (2020). Educação Especial na EJA: análise do processo de construção da prática docente. 2020. 114 f. Dissertação (Mestrado) - Programa de Pós-Graduação em Educação Especial. Universidade Federal de São Carlos, São Carlos, 2020.

[26] RENZULLI, J. O que é esta coisa chama superdotação e como a desenvolvemos? Uma retrospectiva de vinte e cinco anos. Educação, Porto Alegre ano XXVII, n.1 (52), p.75-131, Jan./Abr. 2004.

[27] SAKAGUTI, P., COSTA, M, ELIAS, A. Transdisciplinaridade e enriquecimento curricular no atendimento ao aluno com altas habilidades/superdotação. Educere XII Congresso Nacional de Educação, 2015.

[28] SÃO PAULO (SP). Secretaria Municipal de Educação. Diretoria de Orientação Técnica. Educação de Jovens e Adultos. Educação de Jovens e Adultos: princípios e práticas / Secretaria Municipal de Educação. - São Paulo: SME / DOT, 2016.

[29] ___. Secretaria Municipal de Educação. Coordenadoria Pedagógica. Divisão de Educação de Jovens e Adultos. Educação de Jovens e Adultos: princípios e práticas pedagógicas - volume 2 / Secretaria Municipal de Educação. - São Paulo: SME / DOT, 2008.

[30] ___. Secretaria Municipal de Educação. Coordenadoria Pedagógica. Currículo da Cidade de São Paulo para Educação Física, 2017.

[31] _. Portaria 9.032, de 04 de dezembro de 2017. Estabelece normas complementares para o funcionamento dos CIEJAs, nos termos do contido na lei no $15.648 / 12$, regulamentada pelo decreto $\mathrm{n}^{\circ}$ 53.676/12, alterado pelo decreto no 54.531/13. Disponível em http://www.docidadesp.imprensaoficial.com.br Acesso em: 20 maio 2021. [32] SIEMS, M. Educação de jovens e adultos com deficiência: saberes e caminhos em construção. Educ. foco, Juiz de Fora, v. 16, n. 2, p. 61-79, set 2011/fev 2012. Disponível em http://www.ufjf.br/revistaedufoco/files/2012/08/Texton-031.pdf

[33] VIRGULIM, A. A contribuição dos instrumentos de investigação de Joseph Renzulli para a identificação de estudantes com Altas Habilidades/ Superdotação. Revista Educação Especial | v. 27 | n. 50 | p. 581-610 | set./dez. 2014

[34] VIRGOLIM, A. M. R. Altas Habilidades/superdotação: encorajando potenciais. Brasília: Ministério da Educação, Secretaria de Educação Especial, 2007. 


\section{Capítulo 8}

A atuação do professor de Educação Física na Atenção Básica de Saúde

Daniel Castilho de Souza

Jamila Mariana Martins da Cruz.

Layse de Oliveira Monteiro

Paula Carolina Silva Santos

Pedro Vitor Nascimento de Paiva

Simone de La Rocque Cardoso

Resumo: Esse artigo está centrado sobre de que maneira a interação do professor de educação física na atenção básica de saúde pode contribuir de maneira significativa na obtenção de saúde integral dos indivíduos envolvidos no processo de restabelecimento da saúde. Para isso, o objetivo de pesquisa, nomeadamente o professor atuou com um plano de intervenções com o objetivo de fortalecimento das musculaturas abdominal, lombar, quadril e de alongamento. Assim, se pode observar que tal intervenção por meio do exercício físico foi capaz de interagir de maneira significativa com os demais procedimentos realizados pelos demais profissionais da saúde em UBS da região metropolitana de Belém - PA.

Palavras-Chave: Estratégia Saúde da Família; Qualidade de Vida; Saúde Pública; Educação Física. 


\section{INTRODUÇÃO}

A expectativa de vida da população brasileira cresce a cada ano. 0 conceito de saúde é muito amplo, abrangendo diversos aspectos da vida diária de um indivíduo. Na atualidade o profissional de educação física pode ser encontrado junto as equipes multiprofissionais que atuam nas Unidades Básicas de Saúde (UBS). As UBS configuram-se em um campo de permanente construção do conhecimento à medida que novas categorias profissionais vão sendo incorporadas à Estratégia Saúde da Família (ESF), trazendo novos saberes e novas práticas para a prevenção de doenças e promoção da saúde (ELLERY; PONTES; LOIOLA, 2013). Tem por objetivo mostrar a importância da inserção do professor de educação física junto a equipe de profissionais da saúde em UBS da região metropolitana de Belém - PA.

\section{METODOLOGIA}

A pesquisa-ação foi realizada com cinquenta pessoas entre elas homens, mulheres e adolescentes. Utilizou-se um plano de atividade física composto por "dança com bastão" que objetivou por meio da utilização de movimentos livres e um bastão, evidenciar a diversidade da cultura corporal (SCABAR; PELICIONI; PELICIONI, 2012). Foi proposto cerca de vinte movimentos com duração de um a dois minutos tendo posteriormente, descanso de dez segundos. 0 plano foi realizado em um período de 3 meses em três dias semanais, com duração de 50'min, cada sessão. As aulas foram compostas por aquecimentos e "dança com bastão", sendo alternados entre dias para o fortalecimento das musculaturas abdominal, lombar e quadril e, por fim, o alongamento.

Para a coleta dos dados foi feita a perimetria da circunferência abdominal dos sujeitos no início da primeira sessão e novamente após as 12 semanas. Também foi realizada entrevista, contendo 4 perguntas abertas para os 50 usuários sobre sua percepção de seu estado de saúde atual. As mesmas perguntas foram repetidas ao final da pesquisa. A análise se deu sobre (BARDIN,1997).

\section{RESULTADOS/DISCUSSÕES}

Após as 12 semanas foi constatado que a circunferência abdominal dos pacientes havia diminuído. Houve relatos ainda sobre a melhora das dores localizadas na coluna lombar e no quadril.

\section{CONSIDERAÇÕES FINAIS}

Este estudo evidenciou a importância do professor de educação física junto a equipes de saúde das UBS e sendo considerado seu trabalho de grande relevância para a saúde dos usuários do SUS.

\section{REFERÊNCIAS}

[1] BARDIN, L. Análise de conteúdo. Lisboa: Edições 70, 1977.

[2] ELLERY, A.E.L.; PONTES, R.J.S.; LOIOLA, F.A. Campo comum de atuação dos profissionais da estratégia saúde da família no Brasil: um cenário em construção. R.S.C., R.J., v.23, n.2, p. 415-437, 2013.

[3] SCABAR, T.G.; PELICIONI, A.F.; PELICIONI, M.C.F. Atuação do profissional de Educação Física no Sistema Único de Saúde:uma análise a partir da Política Nacional de Promoção da Saúde e das Diretrizes do Núcleo de Apoio à Saúde da Família - NASF. R.H.S. I.; v. 30, n.4, p.411-8, 2012 


\section{Capítulo 9}

O esporte e o lazer no processo de formação integral dos educandos em uma escola federal em Rio Branco/Acre

Alessandra Lima Peres de Oliveira

Kelly Cebelia das Chagas do Amaral

Denise Jovê Cesar

Eroína Moreira de Melo

Resumo: 0 presente relato busca apresentar alguns aspectos importantes que podem ser desenvolvidos através de atividades esportivas dentro da escola. 0 ensino das modalidades do handebol e futsal para além da técnica, visando promover reflexões e interações propulsoras de uma postura social consciente e crítica, contribuindo também, para a adesão de hábitos saudáveis, manutenção de um melhor estilo de vida e bemestar inerentes em sua prática.

Palavras-Chave: Educação; Esporte; lazer; 


\section{INTRODUÇÃO:}

O esporte é uma manifestação da cultura corporal imprescindível no ambiente escolar, de forma curricular e extracurricular. 0 jogar e o brincar exercem grande influência psicológica nas crianças e adolescentes, principalmente nos períodos de formação do caráter e da personalidade, contribuindo na formação integral do individuo. Na educação física escolar o esporte não deve estar ligado ao ato mecânico, visando o rendimento, e sim auxiliar o aluno a compreender e adotar atitudes que o levem a dominar os valores da cultura esportiva. Neste contexto, aborda-se o esporte e o lazer também como ferramenta pedagógica no processo de ensino e da aprendizagem e como meio de socialização e interação no âmbito escolar, através dos torneios e interclasses nas modalidades de handebol e futsal, contribuindo com a formação dos indivíduos e na construção de valores necessários para o convívio em sociedade. Na escola, assim como nos diferentes espaços sociais, a prática esportiva e o lazer apresentam-se como uma possibilidade para os momentos de ensino e a aprendizagem e o desenvolvimento dos valores sociais, morais e éticos, além dos benefícios relacionados a saúde, ao bem-estar e à qualidade de vida implícitos em sua prática.

\section{OBJETIVOS}

Possibilitar o uso das práticas esportivas e recreativas para o ensino e a aprendizagem dos conteúdos conceituais, atitudinais e procedimentais incentivando a prática de atividades de esporte e lazer, para a qualidade de vida e saúde. Trata-se de um relato de experiência desenvolvido durante as aulas de Educação Física, no ano de 2017, em uma escola federal de Rio Branco- AC.

\section{METODOLOGIA}

Inicialmente os alunos tiveram aulas teóricas e práticas das modalidades de handebol e futsal, para conhecimento e domínio de aspectos desportivos. Durante este processo foram organizados para o final dos bimestres correspondentes a aprendizagem das temáticas, os torneios e interclasses entre todas as turmas do colégio, com a participação dos alunos do sexo masculino e feminino. Os alunos que não compunham as equipes de competição eram convidados a participar da torcida organizada, da equipe de apoio e logística, ou de outras atividades de lazer como jogos de tabuleiros, tênis de mesa, entre outros disponibilizados. Esta metodologia apresentou-se adequada para os objetivos propostos. Durante as aulas teóricas os alunos puderam dialogar sobre as condutas esportivas dos atletas e das torcidas, houve a construção e organização das regras de forma coletiva. Os alunos não participantes das práticas esportivas, foram inseridos nas diversas equipes de organização do evento e/ou participavam de forma recreativa, envolvendo todos os alunos da escola. Foi possível perceber ao final dos torneios que todos os alunos foram inseridos na atividade proposta, participando ativamente no processo de ensino e da aprendizagem, desempenhando suas funções com dedicação e descontração. Constatou-se ainda que não houveram ações violentas nem antidesportivas durante as atividades. Previamente foi estipulado coletivamente que as torcidas seriam motivacionais a todas as equipes, e ao final dos torneios a premiação seria atribuída aos primeiros e segundos lugares de igual modo. 0 processo foi finalizado com a participação de todos os alunos em uma confraternização para socialização e interação dos mesmos.

\section{CONSIDERAÇÕES FINAIS:}

As atividades de esporte e lazer, quando bem desenvolvidas no âmbito escolar, devem buscar a participação coletiva, proporcionando o aprendizado dos conteúdos propostos, por meio de metodologia esportiva e recreativa. Desta forma, favorecendo os aspectos relacionais, emocionais, motores e cognitivos dos alunos, além de possibilitar a aprendizagem da técnica esportiva dentro do fair-play, e despertar o interesse pelo esporte, contribuindo para a construção e manuntenção de hábitos saudáveis, auxiliando assim, a formação integral do indivíduo. 


\section{REFERÊNCIAS}

[1] ASSIS, S.. Reinventando o esporte: possibilidades da prática pedagógica. Campinas, SP:Autores Associados, Chancela Editorial CBCE,2001.

[2] BRACHT, V.. Esporte na escola e esporte de rendimento. Movimento.Porto Alegre, ano 06, n. 12,2000.

[3] COLETIVO DE AUTORES. Metodologia do ensino de Educação Física. São Paulo:Cortez,1992.

[4] STIGGER, M. P.;LOVISOLO, Hugo (Org.). Esporte de rendimento e esporte na escola. Campinas, SP:Autores Associados, 2009.

[5] TUBINO, M. J. G. Dimensões sociais do esporte.São Paulo:Cortez, Autores Associados, 1992. 


\section{Capítulo 10}

Ações educacionais no âmbito da educação física escolar: Desafios e possibilidades em curso $^{7}$

Alysson Carlos Ribeiro Gomes

Jefferson Francisco Cândido

Tatiane Meire Martins

Resumo: 0 presente trabalho se caracteriza por refletir e propor ações, com ênfase na educação física, objetivando ampliar as possibilidades de se trabalhar a cultura corporal.

Palavras Chave: escola; educação física, cultura corporal 


\section{INTRODUÇÃO}

Pensar a educação formal sempre foi uma tarefa complexa, isso porque as relações sociais são, também, complexas. Neste sentido, sendo a educação formadora de personalidades humano-históricas, requer-se uma relação democrática, a qual torna-se difícil em sociedades capitalistas, pois o ato educativo, por excelência, é contraditório a este tipo de sociedade (PARO, 2015, p. 107).

Neste sentido, o presente trabalho se caracteriza por refletir e propor ações, com ênfase na educação física, objetivando ampliar as possibilidades de se trabalhar a cultura corporal.

\section{OBJETIVO}

Analisar ações pedagógicas no contexto da Educação Física Escolar, no âmbito de escolas públicas municipais em Palmas/TO, e problematizar/propor ações que consigam trabalhar os temas da cultura corporal, com os(as) educandos(as) envolvidos nas ações.

\section{METODOLOGIA}

O presente estudo acontecerá por meio de pesquisa qualitativa, a qual, de acordo com Minayo (2001) preocupa-se com níveis de realidades que não podem ser quantificados. Dessa forma, haverá revisão de bibliografia relevante ao tema/discussão, bem como pesquisa de campo a ser realizada na décima primeira edição de um projeto intitulado "Festival para Ser Criança", bem como na rotina das ações previstas dentro da carga horária destinada aos (as) Professores de Educação Física na rede de ensino em questão, as quais são intituladas como: treinamento esportivo. Ambas, realizadas em Unidades Escolares da rede municipal de Palmas/TO, com crianças de seis a nove anos de idade. Em relação à revisão bibliográfica, os livros: Reinventando o Esporte: possibilidades da prática pedagógica, e Transformação didático pedagógica do esporte, serão utilizados para nortear a pesquisa, bem como em relação às proposições.

Após leituras, foram elaboradas ações para serem realizadas na 11a edição do Festival, e também nas ações referentes ao "treinamento". Em relação Festival, ele foi composto de quatro grandes estações, sendo elas: atividades coreografadas - as crianças tinham que realizar movimentos corporais ao som de músicas e ritmos diversos; festival de malabares - equilíbrio de pratos (feitos de materiais recicláveis), bolinhas e argolas; festival de atividades circenses-as crianças deveriam fazer uso de: bolas, arcos, argolas e nariz de palhaço, e criarem apresentações entre elas; trapézios - aproveitou-se o caule e os galhos, para além da bela sombra fornecida por uma Faveira de Bolota, para amarrarem dois slacklines em alusão à corda bamba, um trapézio e duas argolas que serviam para simular o trapézio e demais apresentações aéreas existentes nos mais diversos estilos de circo.

Em relação as ações referentes ao horário dos "treinamentos", duas vezes na semana, sempre no contra turno as crianças iam para a escola para participarem das aulas/treinos. No início de cada aula/treino, cada criança recebia uma bola e tinha a disposição de cinco a dez minutos para brincar, livremente, com a mesma. Este momento inicial é intitulado de festival de criação. Faz parte das aulas/treinos, também, intercâmbio entre Unidades Educacionais que tenham a mesma linha de raciocínio. Ao final de cada semestre, as famílias das crianças são convidadas para jogarem junto com as crianças, com o intuito de ultrapassar os limites físicos da escola, no que diz respeito a fazer chegar até as famílias, a ideia construída no dia a dia das aulas/treinos.

\section{RESULTADO}

Após os estudos, a elaboração das propostas e as execuções, percebe-se que aqueles (as) que participavam, realizavam diversos movimentos de forma espontânea, e confortável, no caso do Festival. Em ralação aos treinamentos, no dia a dia da rotina escolar, tanto as crianças quanto os (as) responsáveis (as) procuravam mais informações sobre o que iria acontecer nos próximo treinos. 


\section{CONSIDERAÇÕES FINAIS}

Com base no que foi estudado, proposto e executado, percebe-se que é possível tratar os conteúdos da cultura corporal para além da possibilidade de jogos internos (turmas contra turmas) e aulas/treinos apenas com mais habilidosos (as). Nesse sentido, Assis (2010, p.22) aborda que a escola é um lugar de construção de um novo esporte, a partir da prática do velho. Ou seja, sugere que haja uma espécie de reinvenção do esporte, por exemplo, por meio de práxis possíveis àqueles que o praticam. Assim, embora os conteúdos da cultura corporal continuam existindo na escola, precisam ser questionados/estudados pelos sujeitos envolvidos na e com a escola.

\section{REFERÊNCIAS}

[1] ASSIS, de Oliveira, Sávio. Reinventando o esporte: possibilidades da prática pedagógica. 3. ed. 1. reimpr.Campinas, SP: Autores Associados, chancela editorial CNCE, 2010.- (Coleção educação física e esportes).

[2] MINAYO, Maria Cecília de Sousa. Pesquisa social: teoria, método e criatividade. Petrópolis: Vozes, 2001.

[3] PARO, Vitor Henrique. Diretor escolar: educador ou gerente? - São Paulo: Cortez, 2015.

[4] TEIXEIRA, Lucia Helena Gonçalves. Cultura organizacional e projeto de mudança em escolas públicas Campinas, SP: Autores Associados, 2002. 


\section{Capítulo 11}

\section{Alunos "Em Cena": Pesquisa pedagógica com mídias tecnológicas na Educação Física escolar}

\section{Renata de Oliveira Carvalho \\ Andressa Ceni Lopes \\ Lediana Ribeiro de Quadros \\ Liziane Nichele Pereira \\ Paulo Gomes Sousa-Filho}

Resumo: 0 estudo apresenta como objetivo fomentar o uso das mídias tecnológicas e digitais no âmbito escolar, bem como proporcionar aos discentes uma experiência que estabelecesse uma aproximação dos conteúdos da Educação Física escolar ao seu cotidiano. Os estudantes trouxeram encenações teatrais, roteiros educativos e descritivos, filmagens de cidadãos e cidadãs da cidade em atividades diversas. Consideramos que as possibilidades de se trabalhar as mídias digitais nas aulas de Educação Física, ainda que simplórias, constituem-se enriquecedoras, haja vista o envolvimento, o aprendizado e os conhecimentos difundidos através da exploração da linguagem audiovisual entre os discentes.

Palavras-chave: Videoaula. Educação Física. Mídias Tecnológicas. Mídias na Educação. 


\section{INTRODUÇÃO}

0 presente artigo aborda uma pesquisa pedagógica de cunho qualitativo e orienta-se em uma monografia ${ }^{8}$ da Especialização em Mídias na Educação da Universidade Federal de Rio Grande (FURG), aprovada em 2016. Nessa pesquisa qualitativa problematizou-se que incorporar as mídias na escola é uma demanda atual, uma vez que vivemos em uma sociedade tecnologizada. Nesse contexto, compreender que os discentes compõem uma geração que "pensa e age" digitalmente passou a ser significativo para o trabalho docente (CARVALHO et. al, 2017). Observa-se também que as tecnologias estão ao alcance das pessoas, independentemente da idade, através do uso de smartphones. Consequentemente, o contexto escolar aponta a necessidade de repensar as ferramentas metodológicas com esta eminente tecnologização da sociedade. Tornou-se importante pensar um currículo escolar que também dialoga e se aproprie das mídias tecnológicas e digitais no processo de ensino-aprendizagem (SERAFIM e SOUSA, 2011). Para tanto, um caminho é deixar de considerar os smarthphones como vilões do aprendizado e da maneira tradicional (quadro e caderno) - que na maioria das vezes prevalecem como metodologia. Não obstante, compreendemos que uma possibilidade metodológica não necessariamente implica na exclusão de outra. 0 que desejamos proporcionar nesta discussão é um olhar às potencialidades de inserção de mídias no processo pedagógico, desmistificando-a. Demonstrando, a partir desta pesquisa pedagógica, que esta inclusão é possível através de iniciativas simples.

A geração contemporânea vive, educa-se e desenvolve-se a base de estímulos muito rápidos e intensos. Carolyn Everson, executiva do Facebook, divulgou que o Instagram atingiu 800 milhões de usuários ativos com 500 milhões acessando o aplicativo diariamente. Esses dados foram divulgados pela profissional em um evento de publicidade em Nova York (MARMENTINI, 2017). Esse fato implica em assumirmos que os usuários do Instagram constituem boa parte das pessoas e que elas por sua vez investem um considerável espaço-tempo de suas vidas assistindo e/ou produzindo vídeos, uma vez que a rede social está em crescimento e propagação paulatinos. Mediante a esse terreno que coloca os docentes diante de alunos conectados digitalmente em grande parte do tempo, as relações pedagógicas necessitam abarcar discussões que possam dialogar com as linguagens e representações as quais os alunos são expostos. Nesse sentido, incluir a produção de material audiovisual como procedimento metodológico é uma possibilidade para promover reflexões, discussões e problematizações acerca do uso das mídias na sociedade.

Léa Fagundes (2010) aborda a necessidade de políticas públicas que atuem na inclusão digital nas escolas, pois há muitos docentes que não sabem por onde começar, uma vez que existe precariedade na oferta de equipamentos digitais na educação pública bem como a falta de formações e capacitações aos docentes. Nos laboratórios de informática muitas vezes se encontram poucos computadores, além de estarem, na maioria das vezes, desatualizados ou sem acesso à internet, exemplificando. A manutenção dos equipamentos é rara e há falta de continuidade dos poucos programas de inclusão tecnológica que por vezes são oferecidos (FAGUNDES, 2010). Iniciam e terminam concomitantemente devido às sucessivas administrações e a frágil infraestrutura técnica, financeira e política. A escola merece ser um espaço para formação e informação em que a aprendizagem de conteúdos oportunize imersão em questões contemporâneas e atuais, abrangendo o aluno integralmente e desenvolvendo capacidades para sua intervenção nos fenômenos sociais e culturais (BRASIL, 2018). Conforme Serafim e Sousa (2011), os estudantes possuem uma vida virtual onde diversas informações são disseminadas, sendo estimulados digitalmente em grande parte do tempo. Esta compreensão demonstra a existência de uma demanda formativa na escola para a problematização deste fenômeno. A escola contemporânea necessita se apropriar do viés educacional das mídias tecnológicas considerando-a objeto passível de estudo. Nesse contexto, tratar dos conhecimentos acerca da segurança das redes, refletir com criticidade acerca das representações produzidas pelas mídias sociais, bem como lançar mão de metodologias que se aproximem deste mundo digitalizado e tecnológico no qual os discentes percorrem já não é mais "coisa do futuro", mas do presente e necessidade da escola de hoje.

É possível considerar que o trabalho com as mídias na educação constitui uma importante discussão para a educação básica e também à Educação Física como disciplina curricular alocada na área das linguagens. Há potencial educativo nas mídias tecnológicas e a escola em suas funções social, instrutiva e educacional (PÉREZ GÓMEZ, 1998) necessita contemplar o contexto social digitalizado o qual estamos inseridos. Ao aproximarmos às mídias da sala de aula, enquanto docentes, oportunizamos o protagonismo dos alunos,

\footnotetext{
${ }^{8}$ A monografia está intitulada "A Produção de Videoaulas em espaços não escolares", de Renata de Oliveira Carvalho e Liziane Nichele Pereira, orientada pelo Prof. Dr. Paulo Gomes Sousa-Filho e foi aprovada em 2016 pela Universidade Federal de Rio Grande, (FURG).
} 
espaços diversificados para construção e partilha de conhecimentos. 0 exercício da criatividade e criticidade também são explorados e saberes que vão ao encontro da autoestima, uso responsável e crítico dessas linguagens digitais e reflexões acerca de sua implicação nas relações e representações de corpo vão sendo oportunizados aos alunos. Ademais, a escola deseja que os discentes sejam protagonistas em suas vidas, detentores de potencial crítico e com condições plenas de planejar um futuro para si (BRASIL, 2018). Em virtude disto, esta pesquisa pedagógica na Educação Física escolar por nós desenvolvida objetivou fomentar um olhar para as potencialidades pedagógicas das mídias tecnológicas. À medida que as práticas escolares oportunizem momentos para o desenvolvimento de saberes e conhecimentos formativos necessários à sociedade da cultura digital contemporânea, o autoconceito, a autoestima e a construção da criticidade se configuraram premissas legítimas no que tange à educação na era digital.

Nos aproximando à problemática desta pesquisa, o eminente crescimento das redes sociais, conforme já mencionado, nos conduziu à compreensão de que grande parte das pessoas tem se sentido atraída a se fotografar e filmar em suas mais variadas atividades cotidianas seja de lazer ou compromissos profissionais. Nesse sentido, é possível observar também o espantoso crescimento da produção de vídeos através do Youtube. Há diversos criadores de conteúdo e alguns atuam inclusive profissionalmente: profissão Youtuber. Os canais do Youtube possuem milhares de inscritos e os conteúdos são os mais variados, desde tutoriais de jogos até o uso de plantas medicinais, exemplificando. Já no Instagram estes vídeos são mais curtos e grande parte dos usuários alimentam a mídia com sucessivos acontecimentos cotidianos denominadas histories, permanecendo disponíveis apenas por um determinado tempo. É possível acrescentar filtros, trilhas sonoras e outros acessórios de forma a incrementar as publicações que são apenas fotografias ou vídeos. Através destes vídeos, pode-se saber o que o Neymar comeu no café da manhã e o que o "meu vizinho" está fazendo no decorrer do seu dia. Consequentemente, é possível aos usuários sentirem-se próximos à "intimidade" do outro. Desse modo, o ambiente digital se posiciona como um espaço que exerce influência no comportamento dos consumidores (LIMA; KANEIPP, 2017) constituindo-se um fenômeno que precisa ser tematizado pela escola.

A Educação Física escolar pode contribuir tematizando em seus conteúdos questões pertinentes às representações e significados que circulam nas mídias. Questionar como o corpo, a cultura corporal do movimento e a saúde tem sido representados nas mídias, bem como a relação das mesmas com a saúde e qualidade de vida, atuando assim de maneira crítica neste cenário (BRASIL, 2018). Por essas razões, juntamente com as turmas dos anos finais do ensino fundamental elencamos os seguintes conteúdos para serem trabalhados nesta pesquisa pedagógica: o conceito de saúde, combate ao sedentarismo, uso das mídias tecnológicas na contemporaneidade, esporte, lazer e qualidade de vida e alimentação saudável. Todos estes conteúdos foram anteriormente trabalhados em aulas no decorrer do semestre, cabendo aos alunos acessar os conhecimentos construídos na sala de aula e desenvolvê-los agora mediante o registro em vídeo de alguma cena que se relacione com estes temas enumerados para esta atividade. Foram envolvidas turmas de sexto ao nono ano, compreendendo quatro turmas e cerca de oitenta alunos e alunas. A ação contou com quatro etapas que envolviam desde o planejamento prévio até a execução e avaliação dos materiais produzidos. Como resultado, os subgrupos trouxeram encenações teatrais, roteiros educativos e descritivos, filmagens de cidadãos e cidadãs da cidade em atividades diversas e puderam experimentar o aprendizado dos conteúdos dentro e fora dos muros da escola, assim como se perceberem sujeitos críticos e atuantes num projeto que condiz com sua linguagem e cultura digital.

\section{METODOLOGIA}

Trata-se de uma pesquisa pedagógica de caráter qualitativo realizada em duas escolas públicas e municipais do Rio Grande do Sul-RS durante as aulas de Educação Física. Está ancorada em uma monografia da Especialização em Mídias na Educação, conforme já elucidado. Foi realizada em dois municípios distintos: Esteio-RS e Viamão-RS, somando quatro turmas de $6^{\circ}$ ao $9^{\circ}$ do ensino fundamental com idades entre 12 e 18 anos. 0 estudo pedagógico qualitativo sucedeu-se mediante a execução de quatro etapas de trabalho pedagógico de uma atividade avaliativa proposta aos alunos. As identidades das escolas foram suprimidas e os nomes dos colaboradores da pesquisa (os alunos) substituídos por fictícios.

Na primeira etapa foi realizada uma aula explicativa e participativa acerca da proposta de trabalho. Justificou-se a abordagem digital demonstrando aos alunos a importância desse engajamento com as mídias tecnológicas e digitais na educação, bem como os seus benefícios e contextos. Foi discutido e tematizado o uso dos smarthphones, uma vez que nessa proposta eles seriam elemento fundamental na execução do trabalho e, consequentemente, na construção dos conhecimentos. Os discentes demonstraram entusiasmo. Em seguida sistematizamos a proposta de trabalho: em grupos de até cinco 
alunos os discentes deveriam criar um videoaula que tematizasse alguns dos conteúdos estudados nas aulas de Educação Física relacionando-o com seu cotidiano. Formulamos exemplos aos discentes, participando também das construções que eles traziam. Os temas elencados pela professora de Educação Física foram baseados nos conteúdos aprendidos nas aulas: o conceito de saúde, combate ao sedentarismo, uso das mídias tecnológicas na contemporaneidade, esporte, lazer e qualidade de vida e alimentação saudável. Por fim, cada grupo de trabalho escolheu nessa etapa um tema para o seu vídeo. A professora de Educação Física esclareceu que nenhum vídeo poderia ser filmado na escola, pois o objetivo da atividade era proporcionar uma interação com os conteúdos no cotidiano existente fora da escola. Poderiam filmar em suas casas, ruas, bairros, pontos da cidade. Qualquer lugar que não fosse à escola.

Na segunda etapa nos períodos das aulas de Educação Física os alunos aprofundaram as discussões acerca do conteúdo escolhido, local de gravação, ideias adicionais, criação de diálogos (quando houvessem), traçando assim o roteiro e o planejamento do seu trabalho. Foi aberta a possibilidade do trabalho individual uma vez que alguns alunos têm dificuldades para se reunirem fora da escola, entretanto, a maioria dos alunos decidiu fazer a atividade em grupo. Alguns alunos decidiram fazer uma dramatização cômica, outros uma espécie de narração com imagens, outros entrevista, uns escolheram realizar um tour pela cozinha para falar sobre alimentação e houve quem definisse por registrar cidadãos utilizando espaços de saúde e lazer da cidade. Todos nós ficamos muito entusiasmados com as ideias e os alunos estavam implicados com a proposta, procurando a professora de Educação Física em outros momentos para pedir dicas e tirar dúvidas.

Na terceira etapa os alunos deveriam partir para a criação dos vídeos-aula que deveriam ter de 1 a 3 minutos e serem gravados através da câmera do celular. Os alunos poderiam enviar via messenger ${ }^{9}$ ou trazer em pendrive. Na etapa subsequente iniciamos as sessões onde todos assistiram aos vídeos uns dos outros na sala de aula juntamente com a professora. Foi uma etapa repleta de significados tanto individuais quanto coletivos, pois para os alunos foi significativo serem assistidos, mas também verem as produções dos seus colegas. Riram, elogiaram a criatividade, reconheceram as ruas, os espaços públicos e também vizinhos e outras pessoas da cidade.

Na quarta e última etapa (fechamento) foi feita uma avaliação com o grupo acerca de como se sentiram durante o trabalho com mídias tecnológicas na aula de Educação Física. Retomamos nessa etapa os conteúdos abordados, os detalhes procedimentais e os aspectos criativos dos vídeos, elencando também as dificuldades encontradas no processo. Os discentes descreveram como significativa a experiência com as mídias na educação que envolveu, em algumas das produções, parte da comunidade escolar. Avaliaram como importantes às discussões com suas famílias, amigos e pessoas da comunidade acerca dos conteúdos temas que aprendiam na escola e manifestaram o desejo de fazerem outra vez.

\section{RESULTADOS}

Os discentes ao compreenderem-se sujeitos da sua aprendizagem e responsáveis pela partilha com seus colegas, vivenciaram a cooperação e o compartilhamento de saberes. As etapas de planejamento e de execução colocaram os alunos em cena à medida que eles próprios empreenderam análises, críticas, reflexões e intervenções quanto às decisões metodológicas do grupo. Precisavam decidir o que filmar e qual a relação que aqueles registros audiovisuais tinham com o tema escolhido por eles. Foram, por sua vez, ao encontro do que aborda o texto da BNCC (BRASIL, 2018, p. 65) supracitado:

[...] mediante a este trabalho com as mídias tecnológicas na educação física escolar os alunos compreenderam e utilizaram uma tecnologia digital para informação e comunicação de maneira crítica, significativa, reflexiva e ética nas diversas práticas sociais, práticas estas em que a escola também se insere". Ademais, se comunicaram por meio de uma diferente linguagem e produziram conhecimentos, resolveram problemas neste projeto autoral e coletivo.

Todos os grupos realizaram a atividade demonstrando sua implicação. É possível compreender que esta atividade foi significativa para os alunos, uma vez que durante as aulas queriam expor e debater suas decisões e desafios na realização da tarefa escolar. A seguir, descreveremos algumas produções dos grupos de alunos:

\footnotetext{
${ }^{9}$ Aplicativo de mensagens do Facebook.
} 
Um dos grupos realizou um vídeo de "tom cômico-trágico" onde havia duas pessoas lado a lado e uma delas estava tendo um ataque cardíaco. A pessoa ao lado não pôde prestar socorro porque estava focada em seu "celular", não vendo que seu amigo precisava de ajuda, mesmo esse tendo acenado e feito gestos. No vídeo, a pessoa permanecia vidrada em seu smartphone enquanto o amigo acenava e acabava "morrendo de infarto do coração", na dramatização. Este vídeo foi bastante engraçado e os alunos referiram que seu objetivo foi fazer uma crítica ao uso exacerbado das redes que implica na dificuldade das relações entre as pessoas na contemporaneidade. Avaliaram que, por vezes, a internet aproxima àqueles que estão longe e nos distancia daqueles que estão perto de nós.

Semelhante a este enfoque, outro grupo abordou a espetacularização de acontecimentos, incidentes e acidentes em detrimento à solidariedade ao prestar socorro. Na encenação dos alunos que ocorreu na rua onde um deles morava, acontecia a dramatização de um acidente de trânsito, também de maneira cômica. 0 grupo utilizou um carrinho de brinquedo daqueles onde crianças de aproximadamente quatro anos de idade cabem dentro, sendo que este instrumento pertencia à irmãzinha de um deles. No acidente o motorista estava caído no chão e um grupo de pessoas em vez de prestar socorro ficava filmando e postando em suas redes sociais. Num dos diálogos da cena uma aluna perguntava ao ferido seu nome e postava em seu Facebook que "sentia-se dolorida com ele". Esse tipo de status da rede social em que o usuário atualiza como está se sentindo é bastante comum. Uma positiva interação entre estes dois grupos aconteceu, referiram que ajudaram uns aos outros na produção destes vídeos.

A aluna Vívian que possui o diagnóstico de fobia social e não tem o hábito de se comunicar verbalmente, como já mencionado, tematizou a alimentação saudável e realizou a atividade sozinha. Em seu vídeo elencou quais alimentos representam riscos à saúde e ainda expôs a composição de alguns alimentos justificando, inclusive, que muitas pessoas substituem água por refrigerantes. Quando esta aluna do sexto ano do ensino fundamental identifica que muitas pessoas não bebem água como deveriam e que isso acarreta em perdas quanto à saúde, ela estabelece uma conexão entre teoria e prática, apropriando-se de condições para intervir através do seu videoaula que teve uma abordagem de alerta e conscientização. Ela finalizou elencando alguns alimentos que ela considera alimentos saudáveis. A aluna mantém comunicação verbal apenas com uma colega da classe e, algumas vezes, com a professora e, nessa tarefa, a discente falou todo o tempo do vídeo. Os colegas ficaram tão entusiasmados com o vídeo em que a colega aparecia falando que ela foi ovacionada por eles com palmas e gritos.

"[...] Ela tá com a cara toda vermelha no vídeo porque ela chorou falando que não ia conseguir falar. Eu disse tu vai conseguir sim! Depois de muitas tentativas ela conseguiu, ela ficou muito feliz de poder entregar o vídeo". (Mãe da aluna Vívian que tem diagnóstico de fobia social. Conversa da mãe com a professora no pátio da escola).

Outro vídeo bastante aclamado foi de um grupo que filmou um skatista da cidade praticando o esporte numa rampa da cidade de Esteio-RS. Os alunos ainda conseguiram que ele desse um depoimento abarcando assim o vídeo no tema "esporte, lazer e qualidade de vida".

"[...] Sora, eu tinha vontade de anda de skate, aí quando vi o cara lá eu decidi que vô tenta aprende a anda". (Aluna do 8o ano durante a etapa de avaliação).

Outro grupo entrevistou uma professora e atual vereadora da cidade que fez uma fala sobre a importância dos espaços de atividade física, saúde e lazer na cidade. Neste mesmo espaço conversaram com um casal de idosos que disseram frequentar regularmente o local. Esse mesmo grupo se deslocou a outro espaço e lá entrevistou um treinador de um time de futebol de crianças sobre a importância do esporte. Nesse vídeo trouxeram a importância social, retratando também aspectos que extrapolam o desenvolvimento motor. Retrataram os potenciais formativos e emancipatórios quando abordaram que o sonho de ser atleta poderia se constituir numa inspiração para crianças e adolescentes no enfrentamento das vulnerabilidades e desigualdades sociais.

Em seguida, um dos grupos composto apenas por alunas optou por fazer uma dramatização. Nesta, uma delas vestiu-se de homem tal qual chamado de "Fabiano" ao lado de sua namorada, a "Saúde". Elas encenaram de maneira cômica o término do relacionamento entre "Fabiano" e "Saúde", onde o namorado afirmava não ter nada em comum com ela. Empregaram bastante criatividade, elaborando um roteiro 
bastante engraçado e alusivo à índices de doenças metabólicas. No diálogo final, o protagonista "Fabiano" recebeu uma ligação da portaria informando-o que o "Sr. Colesterol" estava a sua procura. Ele responde "pode mandar subir!".

Assim, o resultado foi a dedicação dos alunos e o emprego de sua criatividade, uma vez que os grupos apresentaram diferentes produções de vídeos. Outro aspecto relevante, foi a exploração de alguns grupos em espaços públicos nos arredores da escola. Na qualidade de pesquisadores e investigadores, puderam vivenciar uma atuação diferente das quais estão habituados nesses locais, ultrapassando a mera ocupação do seu tempo livre. Além disso, experimentaram uma linguagem diferente para produzirem conhecimentos e serem avaliados. A transmissão oral, expressão corporal e a contribuição visual causaram efeitos positivos, pois, além dos alunos que produziram os vídeos, enquanto assistiam os alunos também referiram gostar de ver seus bairros, seus espaços e características familiares nos vídeos dos seus colegas.

"A gente tá cansado né Sora, sempre caderno ou sempre bola de vôlei e futebol, falando da Educação Física. Tem gente que não sabe jogar. A gente curte fazer coisas diferentes e a gente sabe fazer, mas a escola às vezes não valoriza tanto ou não se interessa em saber, tipo assim, não dá oportunidade pra gente mostra". (Aluna "Mariana", $7^{\circ}$ ano).

Nessa proposta de aulas indutoras do fomento das mídias tecnológicas na Educação Física escolar colocou os "alunos em cena". Isto é, oportunizou que o aluno fosse sujeito na sua formação em um processo interativo e complexo onde cabia a eles irem procurar os "conteúdos vivos" fora dos muros da escola. 0 movimento de lançar mão de aplicativos que eles usam frequentemente para diversão ou ócio para criar videoaulas, fez com que os discentes experimentassem o manejo dos smartphones sob uma diferente intencionalidade: a dimensão pedagógica. Um aparelho tecnológico tão familiar para eles agora receberá uma atribuição nova: recrutado a colaborar com o aprendizado, um amigo do currículo e da escola, não mais um vilão.

Para nós um dos desafios na escola contemporânea é, portanto, criar metodologias voltadas ao envolvimento com um mundo digital onde os discentes atuem de maneira crítica, adquirindo capacidade de utilizar as mais variáveis ferramentas digitais de forma saudável para si mesmo e para o próximo. Nesse sentido, a escola pode em sua função educativa e socializadora (PÉREZ GÓMEZ, 1998) oportunizar iniciativas indutoras que promovam saberes aos discentes quanto ao eminente mundo digital, tencionando saberes e conhecimentos acerca dos ideais distorcidos de sucesso, fama, relações sociais, corpos belos, magros, torneados que são disseminados nas redes. Esse termo demanda que o professor inclua em seu planejamento atenção à formação corpórea, integral, sobretudo ajudando o aluno na construção de um autoconceito orientado pela autoestima e autonomia. Entendemos aqui o autoconceito como a percepção que um sujeito tem de si próprio e o conceito que, devido a isso, constrói a seu próprio respeito (SERRA, 1988). Ademais, foi estabelecida nessa prática pedagógica uma relação entre os conteúdos e a vida real dos discentes mediante a captura audiovisual. Foi proposto um momento para que os alunos refletissem sobre a vivência prática e cotidiana do que se estuda em sala de aula, multiplicando suas experiências à medida que produziam vídeos em ambientes não escolares.

\section{CONSIDERAÇÕES TRANSITÓRIAS:}

Arroyo (2013) diz que a ênfase na urgência de construir e consolidar um sistema nacional articulado parte do diagnóstico de que ele ainda ou não foi construído ou está desarticulado, atrasado no tempo e fora do lugar. Frente a isso, a BNCC aponta a necessidade desse diálogo com a cultura digital e através da execução desse trabalho os discentes puderam vivenciar essa interação (BRASIL, 2018). Mediante ao trabalho proporcionado por esta pesquisa pedagógica os discentes foram produtores de vídeo, peregrinando pelos arredores das escolas e da cidade atrás de uma compreensão balizada pelo conteúdo escolhido pelo grupo. Nessa prática, o protagonismo é um dos aspectos mais relevantes, pois, conforme Betti (2001), as crianças e adolescentes na contemporaneidade têm mais contato com os conteúdos da cultura corporal de movimento como telespectadores passivos e não como participantes e sujeitos ativos, o que se constitui significativo no trabalho pedagógico escolar. Ao encontro disso, nessa ação pedagógica a qual se refere o presente estudo, os alunos deram conta de aproximar os conteúdos desenvolvidos nas aulas de Educação Física ao seu cotidiano. Colocá-los "em cena" como observadores participantes possibilitou sua atuação ativa enquanto cidadão e sujeitos nesta vivência pedagógica com mídias tecnológicas. 
A partir desta pesquisa pedagógica compreendemos ser possível trabalhar com simplicidade partindo do que já é familiar aos alunos e difundido culturalmente por eles. É possível considerar que a proposta do videoaula alcançou seus objetivos e superou as expectativas dos professores envolvidos, pois houve uma grande pluralidade de vídeos, adesão dos alunos e bastante criatividade nas produções em grupo. 0 engajamento entre os conteúdos escolares, a vida tecnológica e a comunidade escolar oportunizou uma reflexão acerca da aplicação prática do que se estuda na escola. Além disso, os alunos vivenciaram a Educação Física e os seus conteúdos para além dos muros da escola. Referiram ainda que a comunidade parabenizava-os pela iniciativa de filmar os espaços públicos de lazer e atividade física, manifestando uma afeição ao formato do trabalho não tradicional.

Consideramos importante a ação ter iniciado pela ressignificação dos smartphones na primeira etapa da ação. Durante o período de planejamento os alunos discutiram muito sobre o excesso de atenção e de tempo dedicado ao uso dos smartphones e redes sociais pelas pessoas. Os próprios alunos, a partir de diálogos, identificaram atitudes que consideravam saudáveis e nocivas quanto ao uso dos smartphones na sociedade, atuaram teatralmente e/ou foram observadores participantes durante a produção, sujeitos na construção de conhecimentos individuais e coletivos, de maneira autônoma. Nesse sentido, para que os alunos pudessem decidir o que era importante ser filmado foi instaurado um processo crítico e reflexivo muito valioso também encharcado pelos saberes construídos em aula. Nos espaços escolhidos, precisaram selecionar os colaboradores de seu vídeo, negociar a participação destes na sua tarefa e elencar perguntas e assuntos para questioná-los. Isso foi colocá-los "em cena", reafirmando-os como protagonistas de seu aprendizado.

Este trabalho com os anos finais do ensino fundamental se configurou numa ação indutora do trabalho com mídias tecnológicas na educação do âmbito escolar. Os alunos tiveram experiências e vivências na interação com a comunidade escolar, os conteúdos, as situações cotidianas, a leitura da sociedade a partir de uma metodologia voltada ao fomento das mídias na educação, onde o uso do celular foi explorado pelo viés pedagógico.

Apesar de ainda existir certa afeição aos modelos mais tradicionais de educação, projetos e estudos como esse que fomentem o uso das mídias tecnológicas na escola poderão, de algum modo, promover efeitos, induzir debates e reflexões. Pensando e repensando o currículo, os conteúdos, a educação, as metodologias e os discentes de maneira integral, cultural e contextualizada. Do ponto de vista do trabalho pedagógico, essa forma de ver e vivenciar o fazer pedagógico instiga o professor a buscar uma ressignificação de instrumentos e procedimentos metodológicos, aproximando as mídias tecnológicas da escola. Metodologias pedagógicas contextualizadas e que coloquem os alunos "em cena" poderão fomentar no âmbito escolar o trabalho pedagógico com as mídias tecnológicas, (re)significando espaços, tempos e instrumentos.

\section{REFERÊNCIAS:}

[1] ARROYO, M. Políticas educacionais, igualdade e diferenças. RBPAE, v. 27, n.1, p. 83-94, jan./abr., 2011.

[2] BAUMAN, Z. Vida para o consumo: a transformação das pessoas em mercadoria. Rio de Janeiro: Jorge Zahar, 2008.

[3] BETTI, M. Mídias: aliadas ou inimigas da Educação Física escolar?. Motriz, vol. 7, n. 2, p. 125-129, jul./dez., 2001.

[4] BISCARO, M. V.; SILVA, F. L. Corpo, mídia e Educação Física. CEDERJ, Revista Educação Pública, 2016. Disponível em <http://educacaopublica.cederj.edu.br/revista/artigos/corpo-midia-e-educacao-fisica>. Acesso em: 06 abril 2018.

[5] BRASIL. Base Nacional Comum Curricular. Ministério da Educação, 2018.

[6] CARNEIRO, V. L. Q. O educativo como entretenimento na TV cultura: um estudo de caso. Tese (Doutorado em Educação), Departamento de Educação, USP, São Paulo, 1997.

[7] CARVAlHO, R. O.; LOPES, A. C.; PEREIRA, L. N. Uma Experiência Pedagógica a Partir de Tecnologias Digitais nas Aulas de Educação Física. 2017. In: Congresso Estadual de Educação Física Escolar, 5., 2017, Lajeado. Anais... Lajeado, 2017, v. 6, p. 118. http://lattes.cnpq.br/8289599611455961

[8] FAGUNDES, L. C.; SATO, L.; MAÇADA, D. L. Aprendizes do futuro: as inovações começaram! MEC, 1999. (Coleção Informática para a Mudança na Educação). Disponível em: < http://repositorio.furg.br/handle/1/1130>. Acesso em: abril 2016. 
[9] FILATRO, A. As teorias pedagógicas fundamentais em EAD. In: LITTO, F. M.; FORMIGA, M. (orgs). Educação a distância: o estado da arte. São Paulo: Pearson Education do Brasil, 2009.

[10] LIMA, R. R.; KNEIPP; V. Profissão youtuber: da segunda tela à cultura fã. In: XIX Congresso de Ciências da Comunicação na Região Nordeste, 19, 2017, Fortaleza. Anais... Fortaleza, 2017, v.19 , p. 12.

[11] MARMENTINI, L. D. Marketing digital: estudo dos formatos de comunicação para empresas do mercado de moda. 2017. 52f. Trabalho de Conclusão de Curso - Departamento de Ciências Administrativas, UFRGS, Porto Alegre, 2017.

[12] MOLL, J.; LEITE, L. H. A. Educação Integral em Tempo Integral: desafios e possibilidades no campo das políticas afirmativas de direitos. Educação em Revista. Belo Horizonte. v. 31, n. 4, p. 17-21, out./dez., 2015.

[13] MÓRAN, J. M. O vídeo na sala de aula. Comunicacão e Educacão, São Paulo, n. 2, p. 27-35, .jan./abr., 1995.

[14] PÉREZ GÓMEZ, A. I. As Funções Sociais da Escola: da reprodução à reconstrução crítica do conhecimento e da experiência. In GIMENO SACRISTÁN, J.; PÉREZ GÓMEZ, A. I. Compreender e Transformar o Ensino. 4 ed. Porto Alegre: ArtMed, 1998.

[15] SERRA, A. V. (1988). O auto-conceito. Análise Psicológica, 6, 1988. p. 101-110.

[16] TEIXEIRA, A. Educação para a democracia. Rio de Janeiro: UFRJ, 1997. 


\section{Capítulo 12}

\section{Uma proposta para integrar o ensino da Física com Educação Física no Ensino Médio}

\section{Fernando Lima Torreiro \\ Eleneide Menezes Alves \\ Romildo de Albuquerque Nogueira}

Resumo: Os PCNEM propõem a articulação dos conteúdos curriculares abordados nas diversas disciplinas. Portanto, a integração entre a Física e a Educação Física através da construção de práticas de ensino envolvendo essas duas disciplinas pode contribuir para um maior interesse dos estudantes tanto na aprendizagem da Física como também no melhor desempenho nas atividades físicas e desportivas. Para realizar a conexão dos saberes entre as duas áreas é necessário unificar as competências e habilidades necessárias tanto para realização de práticas de exercícios e desportivas quanto para compreensão das ideias básicas da Física. Neste trabalho temos o objetivo: (1) investigar se o ensino da Física está presente nos cursos de graduação em Educação Física nas universidades brasileiras; (2) propor descritores de competências que permita ao professor do ensino médio unificar o ensino de Física e Educação Física. Para investigarmos a presença da Física nos cursos de Licenciatura em Educação Física nas Universidades Brasileiras foram analisadas as grades curriculares de vinte e cinco cursos de graduação. Para propor descritores de competências para o ensino integrado das disciplinas de Física e Educação Física nos baseamos nos PCNEM. Os resultados obtidos revelaram que a disciplina de Física não está presente nos componentes curriculares dos cursos de Educação Física e mesmo a Biofísica, que é uma disciplina correlata que aborda temas da Física, só foi identificada na graduação da UFRPE. Descritores de competências para unificação do ensino da Física e Educação Física foram propostos, porém ainda não foram aplicados numa situação concreta de aprendizagem.

Palavras-chave: Interdisciplinaridade, ensino de Física, ensino de Educação Física, descritores de competências. 


\section{INTRODUÇAO}

O ser humano busca o equilíbrio do corpo com a mente, no contato com a natureza, na busca pelos alimentos saudáveis, na prática de atividades físicas e esportivas, na fuga do sedentarismo, numa disputa incessante pela perfeita qualidade de vida. Os licenciados em Educação Física, orientados pelos Parâmetros Curriculares Nacionais do Ensino Médio (PCNEM), têm um importante papel nesta harmonia entre o corpo e a mente dos educandos. Com base nos PCN é possível integrar o ensino da Física ao da Educação Física, visando promover um maior interesse dos estudantes tanto na aprendizagem da Física como um melhor desempenho nas atividades desportivas. Para construção de uma prática que integre essas as duas áreas de conhecimento, necessitamos estabelecer competências e habilidades que possibilite aos docentes de Física e Educação Física a trabalharem nessa nova perspectiva.

Silva Filho (2009), na sua dissertação de mestrado "Física aplicada ao desporto: um estudo interdisciplinar entre Educação Física, Física e Desporto", evidencia as influências de fenômenos físicos durante práticas de verão da era moderna, entre os períodos de 1896 a 2008, ápice dos desportos de alto rendimento, e constata as inter-relações das provas atléticas com fenômenos físicos. Silva- Filho (2009) também relacionou a prática do atletismo ao ensino da Física e investigou como os cursos de Educação Física e Desporto, localizados no Estado do Rio de Janeiro relacionam essas duas disciplinas.

Gomes e Parteli (2001), no artigo intitulado "A Física nos Esportes", ressaltam os exames de diversas atividades esportivas do ponto de vista da Física, utilizando para isso conceitos básicos como os de força, trabalho, potência, leis de escala, entre outros. Atividades físicas importantes como andar, correr, nadar e pular são estudadas, e, em particular, o desempenho destas com o tamanho do atleta é examinado, além da conceituação física, argumentos evolutivos e comparações diversas entre a fisiologia humana e a animal entre outros aspectos.

Gotzaridis (2004), no artigo "Physical Education and Games and Concepts of Physics: An Interdisciplinary Approach" mostra que as pesquisas sistemáticas internacionais têm mostrado que a atitude dos estudantes em relação à Física é mais negativa e que a indiferença dos estudantes está se desenvolvendo progressivamente, começando nos seus primeiros anos de escola e crescendo gradativamente. Segundo o autor, a indiferença dos estudantes varia de acordo com o interesse da unidade temática e principalmente de acordo com a possibilidade do envolvimento direto que lhe é oferecido durante a atividade. Verificouse que era necessário um esforço para estimular os estudantes, tirando-se vantagens dessas descobertas e desenvolvendo suas aplicabilidades. Ainda observou-se a importância de planejar atividades que aumentem o interesse dos estudantes ao requerer e encorajar suas participações ativas no processo de aprendizado. Com isso, espera-se que a abordagem interdisciplinar ofereça uma solução, uma vez que ela fornece meios para enriquecer os planos das atividades com novas ideias, conhecimento e informação, que visam motivar o envolvimento dos estudantes.

Ainda conforme Gotzaridis (2004), esportes, e, sobretudo, jogos estão entre os interesses de qualquer jovem. 0 esforço para conectar a Física com jogos e Educação Física aumenta a participação dos estudantes, os quais passam a participar das atividades com prazer. 0 uso de conceitos físicos durante jogos ajuda os estudantes a perceberem que Física não é apenas uma ciência teórica, aplicada em laboratórios bem equipados. Ela não está dissociada dos eventos cotidianos, mas, ao contrário, está sempre presente na vida de todos.

Diante disso, tem havido muitas publicações relacionadas à Física através dos Esportes desde o fim dos anos oitenta. A maioria dessas publicações foca na tentativa pela mudança de parâmetros ou prevê melhores resultados em atividades atléticas (GOTZARIDIS, 2004).

Como são mostrados nos trabalhos acima a física está presente na prática esportiva de uma maneira indissociável, porém apesar disso a relação entre essas duas ciências ainda não é devidamente explorada no ensino médio.

Neste trabalho estamos interessados: (1). investigar como o ensino da Física está presente nos cursos de graduação em Educação Física nas universidades brasileiras; (2) construir descritores de competências que permita a integração dessas duas áreas.

\section{METODOLOGIA}

A metodologia empregada nesta pesquisa foi documental. Analisamos os conteúdos curriculares de 25 cursos de graduação em Educação Física de importantes universidades brasileiras, visando identificar a presença da Física nesses cursos. Foram também analisadas as competências e habilidades propostas no 
PCN do ensino médio para as disciplinas de Física e Educação Física, com o objetivo de encontrar uma maneira de integrar o ensino dessas duas disciplinas.

Estatística descritiva foi empregada na análise dos dados.

O levantamento sobre presença da Física nos cursos de Licenciatura em Educação Física também levou em consideração disciplinas correlatas com a Física, tais como Física Aplicada, Biofísica, Biomecânica, Cinesiologia, Fisiologia Humana, Fisiologia do Esforço. As escolhas dessas seis disciplinas estão relacionadas direta e indiretamente aos conceitos da Física aplicada no esporte.

A pesquisa proposta foi realizada em 25 (vinte e cinco) instituições de referência no ensino da Educação Física no Brasil, são elas: 1.UFPE; 2.UFRPE; 3.ESEF-UPE; 4.UFPB; 5. UFAL; 6.UFRN; 7.UFPI; 8.UFS; 9.PUCCampinas; 10.UFC; 11.UFSCar; 12.USP; 13.UFRB; 14.UFES; 15.UFF; 16.UFG - Campus Jataí; 17.UFJF; 18.UFLA; 19.UFMA; 20.UFPA - Campus Castanhal; 21.UFAM; 22.UFV; 23.UFU; 24.UFSM; 25.UFPEL.

\section{RESULTADOS E DISCUSSÃO}

\section{A presença da Física e disciplinas correlatas nos cursos de Educação Física do Brasil.}

O gráfico abaixo mostra a presença da Física e disciplinas correlatas na grade curricular das instituições investigadas.

Quadro1: Disciplinas nos Cursos de Licenciatura em Educação Física de Universidades Brasileira que envolva a Física nas suas ementas.

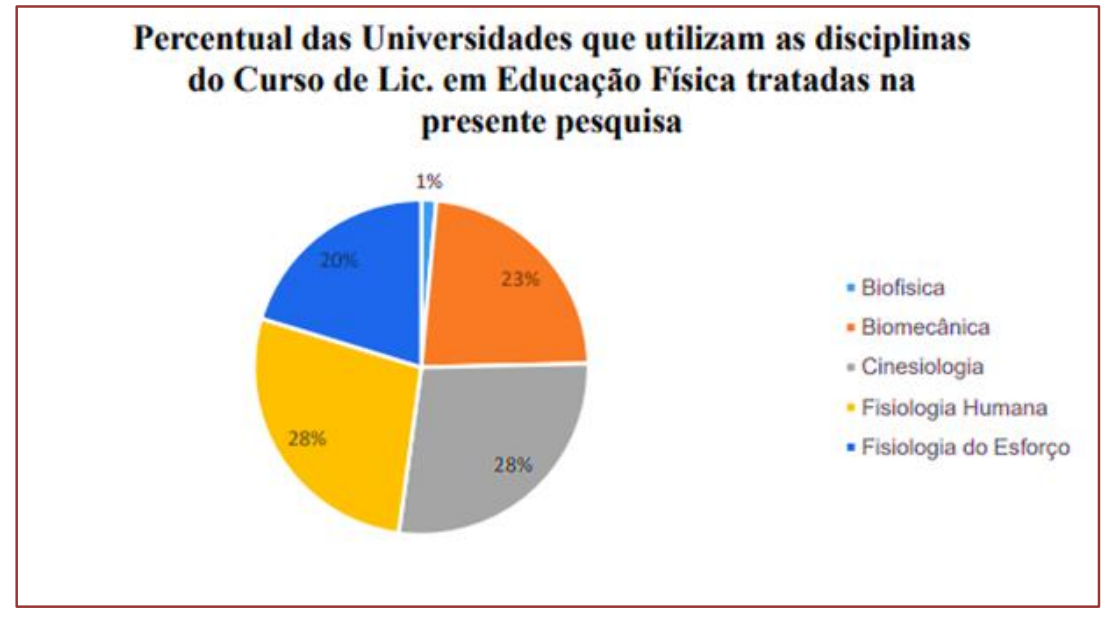

Fonte: pesquisa realizada durante o período de 04.02.14 a 25.02.14.

Fica evidente no gráfico que nenhuma das instituições pesquisadas tem a disciplina de Física Aplicada. Um dado que muito nos chamou atenção foi a presença da disciplina Biofísica (1\%) apenas na UFRPE. As demais instituições apresentaram o seguinte perfil: 23\% ministram a disciplina de Biomecânica; 28\% Cinesiologia; 28\% Fisiologia Humana e 20\% Fisiologia do Esforço. Isso nos leva a acreditar que tais Universidades consideradas de excelência, como as Federais e algumas renomadas Instituições de Ensino superior privadas não reconhecem a importância de ter na sua grade curricular disciplinas voltadas para os conceitos da Física, compondo seu programa de ensino na formação do profissional em Educação Física.

A necessidade da inclusão de métodos físicos na formação do Educador Físico, visando o desenvolvimento do ensino da Educação Física.

A falta de interesse dos estudantes pelo ensino de Física é uma realidade constante, assim como pela prática da Educação Física, em razão da maneira como são trabalhados os conteúdos da Física e Educação Física no Ensino Médio. Um projeto interdisciplinar poderia integrar as duas áreas do conhecimento, possibilitando tornar atraente a prática da Educação Física, utilizando-se nesta os conceitos de Física.

A nossa análise mostra que nos cursos de graduação em Educação Física no Brasil existe uma grande carência das bases da Física para compreensão das práticas de exercícios e dos esportes. 
Uma possível justificativa para discreta presença das Ciências da Natureza e da Física em particular, pode ser decorrente do fato que as duas grandes correntes de ensino da Educação Física, que são a construtivista e a crítico-superadora, apesar de apresentarem propostas integradoras para o ensino da Educação Física, foram teorias que não avançaram na direção da aplicação das Ciências da Natureza, e em particular da Física, na prática da Educação Física. A primeira foi construída por João Batista Freire (1989) com base no referencial piagetiano. A segunda proposta é de um Coletivo de Autores (1992) e tem como referência teórica o pensamento de Karl Marx (2008). As duas propostas assumem a perspectiva do trato com o ser humano valendo-se de sua totalidade e promovendo a superação da fragmentação da pessoa e do conhecimento.

A grande questão então é como integrar o ensino da Física ao da Educação Física, quando os licenciados em Educação Física não receberam uma formação adequada para realizar esta integração.

Por esta razão analisaremos a seguir os PCN para o ensino da Física e da Educação Física, visando construir descritores de competências que permitam aos licenciados em Física Educação Física integrar as duas disciplinas.

Do que tratam os PCNEM no que diz respeito ao Ensino da Física.

Documentos oficiais do Ministério da Educação e Cultura estabelecem as competências (saber) e habilidades (saber fazer) necessárias para que o professor se aproprie desses saberes a fim de desenvolver as habilidades de Ensino de Física para serem aplicadas em sala de aula no Ensino Médio:

Quadro2: Competências e habilidades a serem desenvolvidas em Física segundo os PCNEM.

\begin{tabular}{|c|c|}
\hline $\begin{array}{c}\text { Representação } \\
\text { e } \\
\text { comunicação }\end{array}$ & $\begin{array}{l}\text { - } \quad \text { Compreender enunciados que envolvam códigos e símbolos físicos. } \\
\text { - } \quad \text { Compreender manuais de instalação e utilização de aparelhos. } \\
\text { Utilizar e compreender tabelas, gráficos e relações matemáticas gráficas para a } \\
\text { expressão do saber físico. Ser capaz de discriminar e traduzir as linguagens } \\
\text { matemática e discursiva entre si. } \\
\text { Expressar-se corretamente utilizando a linguagem física adequada e elementos de sua } \\
\text { representação simbólica. Apresentar de forma clara e objetiva o conhecimento } \\
\text { apreendido, através de tal linguagem. } \\
\text { - Conhecer fontes de informações e formas de obter informações relevantes, sabendo } \\
\text { interpretar notícias científicas. }\end{array}$ \\
\hline $\begin{array}{l}\text { Investigação } \\
\text { e } \\
\text { compreensão }\end{array}$ & $\begin{array}{l}\text { - Desenvolver a capacidade de investigação física. Classificar, organizar, sistematizar. } \\
\text { - Identificar regularidades. Observar, estimar ordens de grandeza, compreender o } \\
\text { conceito de medir, fazer hipóteses, testar. } \\
\text { Conhecer e utilizar conceitos físicos. Relacionar grandezas, quantificar, identificar } \\
\text { parâmetros relevantes. Compreender e utilizar leis e teorias físicas. } \\
\text { - Compreender a Física presente no mundo vivencial e nos equipamentos e } \\
\text { procedimentos tecnológicos. Descobrir o "como funciona" de aparelhos. } \\
\text { Construir e investigar situações-problema, identificar a situação física, utilizar } \\
\text { modelos físicos, generalizar de uma a outra situação, prever, avaliar, analisar } \\
\text { previsões. } \\
\text { Articular o conhecimento físico com conhecimentos de outras áreas do saber } \\
\text { científico. }\end{array}$ \\
\hline $\begin{array}{l}\text { Contextualização } \\
\text { sócio-cultural }\end{array}$ & $\begin{array}{l}\text { - Reconhecer a Física enquanto construção humana, aspectos de sua história e relações } \\
\text { com o contexto cultural, social, político e econômico. } \\
\text { - Reconhecer o papel da Física no sistema produtivo, compreendendo a evolução dos } \\
\text { meios tecnológicos e sua relação dinâmica com a evolução do conhecimento científico. } \\
\text { - } \quad \text { Dimensionar a capacidade crescente do homem propiciada pela tecnologia. } \\
\text { Estabelecer relações entre o conhecimento físico e outras formas de expressão da } \\
\text { cultura humana. } \\
\text { - Ser capaz de emitir juízos de valor em relação a situações sociais que envolvam } \\
\text { aspectos físicos e/ou tecnológicos relevantes. }\end{array}$ \\
\hline
\end{tabular}


Outro aspecto importante dos Parâmetros Curriculares Nacionais do Ensino Médio é a proposta da construção interdisciplinaridade como uma prática pedagógica e didática:

A interdisciplinaridade deve ir além da mera justaposição de disciplinas e, ao mesmo tempo, evitar a diluição delas em generalidades. De fato, será principalmente na possibilidade de relacionar as disciplinas em atividades ou projetos de estudo, pesquisa e ação, que a interdisciplinaridade poderá ser uma prática pedagógica e didática adequada aos objetivos do Ensino Médio (BRASIL, 1999. P.88).

Detro da visão descrita acima para realizar a interdisciplinaridade propomos integrar o ensino da Física ao da Educação Física. Esta é uma prática de ensino inovadora, e pode ser de grande importância para o processo de ensino-aprendizagem dessas duas disciplinas no ensino médio.

Para integrar as duas disciplinas numa proposta interdisciplinar precisamos construir descritores de competências a serem desenvolvidas nas aulas integradas de Física e Educação Física.

Atualmente do licenciado em Educação Física se exige que desenvolva competências e habilidades para uma prática docente que integre corpo e a mente de seus educandos. Na tabela abaixo são mostradas as competências e habilidades a serem desenvolvidas pelos professores em Educação Física em seus educandos:

Quadro3: Competências e habilidades a serem desenvolvidas em Educação Física segundo os PCNEM.

\begin{tabular}{|c|c|}
\hline $\begin{array}{l}\text { Representação } \\
\text { e } \\
\text { comunicação }\end{array}$ & $\begin{array}{l}\text { - Demonstrar autonomia na elaboração de atividades corporais, assim como } \\
\text { capacidade para discutir e modificar regras, reunindo elementos de várias } \\
\text { manifestações de movimento e estabelecendo uma melhor utilização do } \\
\text { conhecimento adquiridos sobre a cultura corporal. } \\
\text { Assumir uma postura ativa na prática de atividades físicas, e conscientes da } \\
\text { importância delas na vida do cidadão. } \\
\text { Participar de atividades em grandes e pequenos grupos, compreendendo as } \\
\text { diferenças individuais e procurando colaborar para que o grupo possa atingir os } \\
\text { objetivos a que se propôs. } \\
\text { Reconhecer na convivência e nas práticas pacificas, maneiras eficazes, de } \\
\text { crescimento coletivo, dialogando, refletindo e adotando uma postura democrática } \\
\text { sobre diferentes pontos de vista postos em debate. } \\
\text { Interessar-se pelo surgimento das múltiplas variações da atividade física, } \\
\text { enquanto objeto de pesquisa e área de interesse social e de mercado de trabalho } \\
\text { promissor. }\end{array}$ \\
\hline $\begin{array}{l}\text { Investigação } \\
\text { e } \\
\text { compreensão }\end{array}$ & $\begin{array}{l}\text { - Compreender o funcionamento do organismo humano de forma a reconhecer e } \\
\text { modificar as atividades corporais, valorizando-as como melhoria de suas aptidões } \\
\text { físicas. } \\
\text { Desenvolver as noções de esforço, intensidade e frequência, aplicando-as em suas } \\
\text { práticas corporais. } \\
\text { Refletir sobre as informações especifica da cultura corporal, sendo capaz de } \\
\text { discerni-las e reinterpretá-la em bases cientificas, adotando uma postura } \\
\text { autônoma, na seleção de atividades procedimentos para a manutenção ou } \\
\text { aquisição de saúde. }\end{array}$ \\
\hline $\begin{array}{l}\text { Contextualização } \\
\text { sócio-cultural }\end{array}$ & $\begin{array}{l}\text { - Compreender as diferentes manifestações da cultura corporal, } \\
\text { reconhecendo e valorizando as diferenças de desempenho, linguagem e } \\
\text { expressão. }\end{array}$ \\
\hline
\end{tabular}

Fonte: Brasil. MEC. PCNEM, Brasília: Ministério de Educação, 1999. P.167.

\section{Competências para desenvolver projetos integrados em Física e Educação Física:}

Após análise das competências e habilidades propostas pelos PCN para o ensino de Física e Educação Física propomos descritores de competências para realização das práticas integradas dessas duas disciplinas e que são apresentados em nossa conclusão. 


\section{CONCLUSÃO}

Nossa investigação mostrou que o ensino da Física não está presente nos cursos de graduação em Educação Física nas universidades brasileiras. Em decorrência deste fato, está sendo proposto neste trabalho integrar o ensino da Física ao de Educação Física. Para operacionalizar essa proposta foram desenvolvidos no presente trabalho descritores de competências para prática integrativa dessas duas disciplinas. Esses descritores permitirão aos docentes descrever as diversas práticas esportivas e de atividade física com base nos conceitos físicos; reconhecer e saber utilizar corretamente símbolos, códigos e nomenclaturas de grandezas da Física e sua aplicação nas diversas atividades físicas, individuais e em grupos; conhecer as relações que envolvem diferentes grandezas físicas na execução de exercícios e práticas esportivas e as possibilidades de movimento do corpo humano; compreender que a Física não é apenas um conjunto de Leis da Natureza acompanhada de fórmulas, mas uma contextualização do pensamento científico e que pode ser aplicada na compreensão do funcionamento do organismo humano através das atividades corporais que valorizam e melhoram as aptidões físicas e, finalmente, identificar através de linguagens gráficas os diferentes tipos de movimentos físicos, relacionando estes com atividades físicas que trabalhem a postura autônoma e contribuam para a manutenção ou aquisição de saúde. Trabalhos práticos com base nesses descritores estão sendo desenvolvidos por nosso grupo de pesquisa e serão objetos de outros trabalhos.

\section{REFERÊNCIAS}

[1] BRASIL, PCN Ensino Médio: orientações curriculares para o ensino médio, Ciências da natureza, matemática e suas tecnologias. Brasília: Ministério da Educação/ SEB, 2006.

[2] BRASIL, Secretaria de Educação Média e Tecnologia. Parâmetros Curriculares Nacionais: Ciências da Natureza, Matemática e suas Tecnologia-Brasilia: MEC; SEMETEC, 1999.

[3] BRASIL, SEMTEC. PCN+ Ensino Médio: orientações educacionais complementares aos Parâmetros Curriculares Nacionais. Brasília: MEC, SEMTEC, 2002.

[4] COLETIVO DE AUTORES. Metodologia do ensino da educação física. Campinas-SP: editora Cortez, 1992.

[5] FREIRE, João Batista. Educação de corpo inteiro-teoria e prática da Educação Física. São Paulo : Scipione,1989.

[6] GOMES, M.A.F. e PARTELI, E.J.R. A Física nos Esportes. Revista Brasileira de Ensino de Física vol.23, no․1, Março, 2001,pp.10-17.

[7] GOTZARIDIS, Christos. Physical Educationand Games, and Concepts of Physics: An Interdisciplinary Approach. Revista: Science Education International vol.15, no 2, June, 2004, pp.160-166.

[8] MARX, K. Contribuição à crítica da economia política. 2. ed. São Paulo: Editora Expressão Popular, 2008.

[9] SILVA FILHO, Amaro José da; Física Aplicada ao Desporto: Um estudo interdisciplinar entre Física, Educação Física e Desporto, dissertação de MSc. PPEMC/CEFET/RJ, Rio de Janeiro RJ, Brasil, 2009 


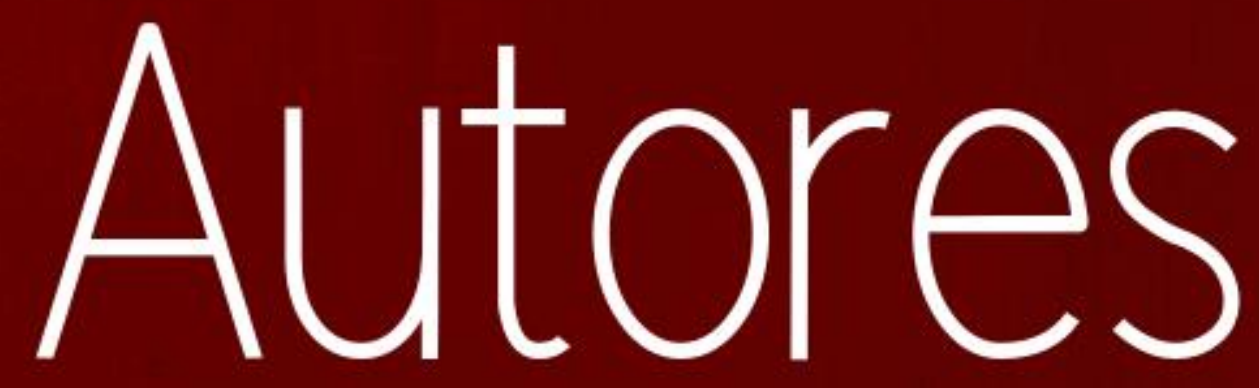




\section{ADRIANA DELLA GATTA SOARES}

É artista e professora. Desenvolve trabalhos na área de artes cênicas e cinema. Acredita na arte como agente transformador e necessário para formação do cidadão.

\section{ALESSANDRA LIMA PERES DE OLIVEIRA}

Licenciada em Educação Física pela Universidade Federal do Acre. Especialista em Educação Física Escolar. Professora efetiva no Colégio de Aplicação /UFAC. Supervisora do Programa PIBID 2019 no CAp/UFAC. Pesquisadora do Centro de Desenvolvimento de Pesquisa em Políticas de Esporte e de Lazer da Rede Cedes da Universidade Federal do Acre.

\section{ALEX DE FREITAS PINTO}

Possui graduação em Educação Física pela UFC-Universidade Federal do Ceará (2002). Cursou Especialização em Gerontologia pela UFC- Universidade Federal do Ceará com conclusão em (2005). Cursou Especialização em Gestão e Coordenação Escolar pela Faculdade Darcy Ribeiro com conclusão em (2014). É Mestre pela Universidade Federal do Rio Grande do Norte pelo Programa de Mestrado Profissional em Educação Física em Rede Nacional-PROEF (2020). Admissão em (2005) como Professor de Educação Física na Rede Estadual de Ensino do Estado do Ceará (SEDUC), onde atua atualmente como professor efetivo do Ensino Médio. Foi Diretor escolar da Rede Municipal de Fortaleza nas escolas EM Francisco Silva Cavalcante e EM Professor José Rebouças Macambira, no período de (2013 a 2018). Admissão em (2016) como Professor de Educação Física da Rede Municipal de Ensino do Município de Fortaleza, atuando atualmente como professor efetivo do Ensino Fundamental (SME).

\section{ALINE APARECIDA RIBEIRO}

Graduada em Fisioterapia pela Universidade Sagrado Coração (2008), Pós Graduada em Saúde da mulher e Dermato funcional pela Universidade Sagrado Coração (2012). Atualmente cursa Pósgraduação em ABA na Deficiência Intelectual e Autismo, Mestranda no Programa de Ciências da Motricidade pela Faculdade de Ciências da Unesp - Bauru. Fisioterapeuta na Apae de Pederneras e nas Clínicas Integrada e Conectiva. Cursou o Conceito Bobath Básico, Avançado e Baby (2018 / 2019), Aplica as Avaliações GMFM, Teste de Screening Denver II e HINE, atua principalmente nos eixos: Fisioterapia Neurológica, Estimulação Precoce, Habilitação e Reabilitação Física.

\section{ALYSSON CARLOS RIBEIRO GOMES}

Licenciatura Plena em Educação Física - Universidade Norte do Paraná (2005). Especialista em Educação Física Escolar - FALBE (2007/08), Gestão Educacional - UFSM (2009/10). Curso de Aperfeiçoamento em atividade física para pessoas com deficiência - UFJF (2012). Mestrando em Educação - PPGE/UFT (2020/22), vinculado ao Grupo de Pesquisa - Rede de Escolas Criativas RIEC/TO. Professor efetivo de carreira, desde 2005, na rede pública municipal de Palmas Tocantins. Professor no curso de Educação Física da Faculdade de Palmas - FAPAL desde 2012. Associado ao CBCE-TO, vinculado ao GTT-Escola.

\section{ANDRESSA CENI LOPES}

Possui graduação em Fisioterapia pelo Centro Universitário Metodista - IPA (2011) e graduação em Educação Física pela Universidade Federal do Rio Grande do Sul - UFRGS (2014). Instrutora de Pilates formada pelo instituto Valéria Figueiredo. Mestre pelo Programa de Pós-graduação em Ciências do Movimento Humano da UFRGS (2016). Membro do Grupo de Estudos Qualitativos Formação de Professores e Prática Pedagógica em Educação Física e Ciências do Esporte (F3pEFICE). Professora de Educação Física (desde 2015), do Projeto de Atletismo Escolar (desde 2016) e Coordenadora de Projetos do Mais Educação (desde 2017) na escola EMEF Vila Monte Cristo da Rede Municipal de Ensino de Porto Alegre (RMEPOA). 


\section{ANTONIO JANSEN FERNANDES DA SILVA}

Possui graduação em Educação Física pela Universidade do Estado do Rio Grande do Norte (2007), especialista em Educação Física Escolar pela Faculdades Nordeste (2009) e Treinamento Esportivo pela Universidade Estadual do Ceará (2012). Mestre em Educação Física Escolar pela Universidade Federal do Rio Grande do Norte (UFRN). Membro do Grupo de Pesquisa em Educação Física Escolar - SABERES EM AÇÃO, vinculado ao Instituto de Educação Física e Esportes da Universidade Federal do Ceará IEFES/UFC. Tem experiência na área de Educação Física, com ênfase na Educação Física Escolar.

\section{BRYAN KENNETH MARQUES PEREIRA}

Graduado em Educação Física pela Universidade Estadual da Paraíba - UEPB (2013), especialista em Treinamento Desportivo pela Universidade Candido Mendes - UCAM (2014) e mestre em Educação Física pelo Programa de Pós-Graduação em Educação Física em Rede Nacional - PROEF/UFRN (2020).

\section{CARINA LOPES MOREIRA}

Graduada em Terapia Ocupacional pela Universidade do Sagrado Coração. Pós Graduada em Psicopedagogia também pela Universidade do Sagrado Coração. Mestranda no Programa de Pós da Graduação em Ciências da Motricidade da Faculdade de Ciências da UNESP - Bauru. Atua na cidade de Bauru - SP como Terapeuta Ocupacional no EINAI - Espaço Multidisciplinar com foco em neurologia infantil e abordagens de Integração Sensorial e Psicomotricidade, consultoria escolar e ministrante de oficinas para formação profissional. Atua também na Casa do Circo como Professora de Atividades Circenses e idealizadora do Projeto de Circo Adaptado para Pessoas com Deficiência. Possui formação básica em Integração Sensorial e formação no Conceito Bobath Infantil. Participou como co-autora e supervisora de campo no projeto de Iniciação Científica que promove a prática circense como mais um recurso terapêutico adotado junto ao desenvolvimento neuropsicomotor de crianças com deficiência.

\section{DAIANE ALMEIDA RODRIGUES}

Bacharel em educação física pela FESGO

\section{DANIEL CASTILHO DE SOUZA}

Pós graduado em Fisiologia do Exercício e Educação Especial Inclusiva pelo Centro Universitário Leonardo da Vinci, professor colaborador da Universidade do Estado do Pará junto ao Grupo de Pesquisa em Saúde infanto-juvenil e Atividade Física Adaptada. Experiência em prescrição de exercícios físicos para grupos especiais e educação inclusiva.

\section{DENISE JOVE CESAR}

Possui graduação em Educação Física pela Universidade Federal de Mato Grosso do Sul (1990), mestrado em Educação pela Universidade Federal de Mato Grosso do Sul (UFMS - 2004) e Doutorado em Ciências pela Universidade Federal de São Paulo (UNIFESP - 2019) Atualmente é professora do Instituto Federal de Santa Catarina, lotada no Campus Caçador. Tem experiência na área de Educação Física, com ênfase em Educação Física Escolar, atuando principalmente nos seguintes temas: Obesidade em adolescentes, Exercício Físico, Educação Física Escolar, Atividade Física e Saúde.

\section{ELENEIDE MENEZES ALVES}

Graduação em Biologia - UPE; especialização em Biologia animal - UFPE; Atualização em Biologia USP; Mestrado em Ensino das Ciências - UFRPE; Doutoranda em Educação em ciências: química da vida e saúde - UFRGS; Professora de Biologia no Ensino Médio da Rede Pública de Ensino de Pernambuco- PE; Docente universitária da FALUB - Faculdade Luso Brasileira -PE nos cursos de 
Pedagogia, letras e serviço social; professora depós graduação da mesma instituição nos cursos de psicopedagogia, letras e literatura.

\section{EROÍNA MOREIRA DE MELO}

Graduada em Licenciatura em Educação Física pela Universidade Federal do Acre - ano 2016 Especialista em Educação Inclusiva, Especial e Políticas de Inclusão. estranda no Programa de Ciências da Saúde da Amazônia Ocidental/ UFAC!

\section{FERNANDO LIMA TORREIRO}

Graduado em Licenciatura em Educação Física - Universidade Federal Rural de Pernambuco (UFRPE) Faixa Preta 1o Dan em Kickboxing - World Kickboxing Federation Singapore (WKF) Instrutor em Muay Thai 11th KHAN - S.E.R.C.S.U INTERNATIONAL ORGANIZACION DE LOS SISTEMAS ESTRATEGICOS REALISTAS DE COMBATE Y SOBREVIVENCIA URBANA Instrutor em Defesa Pessoal - Associação Tigre de Artes Marciais Instrutor em Chi Kung - Associação Tigre de Artes Marciais Key English Test - University of Cambridge

\section{JAMILA MARIANA MARTINS DA CRUZ}

Acadêmica de Licenciatura em Educação Física na Universidade do Estado do Pará - UEPA. É bolsista no Programa Institucional de Bolsas de Iniciação Científica e de Desenvolvimento Tecnológico e Inovação (PIBIC-FAPESPA). É monitora voluntária no projeto de extensão Laboratório de Atividade Física Adaptada - LAFAD/UEPA.

\section{JEFFERSON FRANCISCO CÂNDIDO}

Licenciatura Plena em Educação Física - Universidade Federal de Goiás (CAJ- Campus Avançado de Jataí - em 2000). Especialista em Educação Física Escolar pela FALBE (2007/08), Gerontologia: a inserção do velho no mundo contemporâneo pela UFT (2009/10), Educação Infantil, Especial e TGD, pela FAVENI (2015/16). Professor efetivo, de carreira, desde 2003, na rede pública estadual do Tocantins, e também na rede pública municipal de Palmas Tocantins desde 2006. Professor no curso de Educação Física da Faculdade de Palmas - FAPAL desde 2014. Associado ao CBCE-TO, vinculado ao GTT-Escola.

\section{JOHNATHAN PEREIRA DE CASTRO}

Especialista em Educação Física pela UFG

\section{JULIANA CRISTINA SILVA}

Graduada em Educação Física (Licenciatura e Bacharelado) pela Universidade Federal de Uberlândia (2017). Mestrado em Ciências da Saúde pelo Programa de Pós-Graduação em Ciências da Saúde (2020). Durante a graduação, atuou em projetos de pesquisa e extensão, tendo como temas a realização de atividades ligadas aos hábitos de vida e atividades físicas na terceira idade e pessoas com deficiência.

\section{KELLY CEBELIA DAS CHAGAS DO AMARAL}

Mestre em Educação pela Universidade Federal de Mato Grosso do Sul, Graduação em Educação Física pela Universidade Federal do Acre, especialista em Psicopedagogia pela IVE (Faculdades Integradas de Varzea Grande) e Gestão do Esporte e Lazer pelo IESACRE (Instituto de Educação Superior do Acre). Atua na área de Educação Física Escolar no Colégio de Aplicação da Universidade Federal do Acre desde 2002. Pesquisadora e admiradora da infância, jogos e brincadeiras. 


\section{LARISSA HENRIQUE FERRARI}

Discente do último ano do curso de Fisioterapia pelo UNISAGRADO (2021). Atua na linha de pesquisa de Fisioterapia Cardiorrespiratória. Autora do projeto de Iniciação Científica intitulado "Práticas circenses: uma nova perspectiva de recurso terapêutico no desenvolvimento neuropsicomotor", apresentado recentemente no XXVI Fórum de Iniciação Científica do UNISAGRADO. 0 projeto promove a prática circense como mais um recurso terapêutico adotado junto ao desenvolvimento de crianças com deficiência.

\section{LAYSE DE OLIVEIRA MONTEIRO}

Acadêmica de educação física, sétimo semestre, monitora do laboratório de atividade física adaptada (LAFAD), por 3 anos (2017-2019), bolsista no programa PET-saúde Graduasus (2018), estagiária no espaço Arima (espaço terapêutico-2018).

\section{LEANDRO REZENDE}

Possui graduação em Licenciatura em Educação Física pela Universidade Federal de Uberlândia (1986) e mestrado em Educação pela Universidade Federal de Uberlândia (2006). Atualmente é professor aposentado do ensino básico, técnico, tecnológico da Escola de Educação Básica da Universidade Federal de Uberlândia. Possui trabalhos na área de Educação Física Escolar, com ênfase em metodologias de ensino, atuando principalmente nos seguintes temas: educação física, educação física escolar, estratégias de ensino, escola e Educação Física, o jogo, o esporte, lutas, expressão corporal, ginástica e inclusão dos alunos público alvo da educação especial nas aulas de Educação Física. Na área de Educação, tem experiência nos temas inclusão escolar e na questão da organização do trabalho escolar, atuando principalmente nos temas: políticas públicas, gestão do tempo e espaço escolar.

\section{LEDIALEDIANA RIBEIRO DE QUADROS}

Professora de Educação Física pela Prefeitura Municipal de Criciúma/SC (PMC), graduada em Educação Física-Licenciatura pela Universidade do Extremo Sul Catarinense (UNESC), pesquisadora do Grupo de Estudos e Pesquisa em Desenvolvimento Docente e Prática Educativa (GPOM) pela Universidade Federal de Santa Catarina (UFSC) e do Grupo de Estudos Qualitativos Formação de Professores e Prática Pedagógica em Educação Física e Ciências do Esporte (F3P-EFICE). Pela Árbitra pela Federação Catarinense de Basquetebol (FCB) e Liga Sul Catarinense de Basquetebol (LSCB), mestra em Ciências do Movimento Humano pela Universidade Federal do Rio Grande do Sul (UFRGS) e graduanda em Educação Física-Bacharelado pela Escola Superior de Criciúma (ESUCRI).

\section{LIZIANE NICHELE PEREIRA}

Especialista em Gestão Pública Municipal em Ênfase Local pela Escola Nacional de Administração Pública - ENAP (Presencial - 2018), Especialista em Mídias na Educação pela Universidade Federal de Rio Grande (Semipresencial - 2016). Atualmente é Diretora Financeira da Secretária Municipal de Educação do Município de Viamão/RS, consultora e Palestrante na área de Educação Financeira Pública, Professora de cursos profissionalizantes e Orientação de trabalhos acadêmicos, com ênfase em Tutoria.

\section{MARCELA FONTÃO NOGUEIRA}

Mestre em Educação Especial pela Universidade Federal de São Carlos (PPGEES/ UFSCar). Professora de Atendimento Educacional Especializado na Prefeitura Municipal de São Paulo no Centro Integrado de Educação de Jovens e Adultos CIEJA Perus I. Especialista em Educação Física Escolar, Educação Especial com ênfase em Deficiência Auditiva/Surdez e Altas Habilidades/Superdotação. Pesquisadora do Grupo de Estudo em Atividade Física Adaptada e Esporte Paralímpico, do(a) Universidade Estadual de Campinas. 


\section{MARCUS PEIKRISZWILI TARTARUGA}

Doutro em Ciências do Movimento Humano pela Universidade Federal do Rio Grande do Sul (UFRGS) em dupla diplomação (co-tutela) com a Université de Nice Sophia Antipolis (UNSA/France). Atualmente é professor efetivo da Universidade Estadual do Centro-Oeste (UNICENTRO), vinculado ao Departamento de Educação Física de Guarapuava (DEDUF/G), coordenador do Grupo de Pesquisa em Biomecânica e Energética do Movimento Humano (MEMH) e integrante permanente do Programa de Pós-graduação em Educação Física da Universidade Estadual do Paraná (PGEDF/UFPR).

\section{MARIA APARECIDA DIAS}

Professora Associada do Departamento de Educação Física da Universidade Federal do Rio Grande do Norte; Chefe do Departamento de Educação Física/UFRN Vice coordenadora do Grupo de Pesquisa em Tecnologia Assistiva (GETA/UFRN); Membro do Grupo de PesquisaCorpo e Cultura de Movimento (GEPEC/UFRN); Coordenadora da Linha de Pesquisa Corpo, Cultura de Movimento e Inclusão (GEPEC/UFRN); Membro do Grupo de PesquisaGestão, Educação, Trabalho e Saúde (GETS/UFRN); Membro da Linha de Pesquisa Educação e Inclusão em Contextos Educacionais; Professora do Programa de Pós-Graduação em Educação/UFRN; Professora do Programa de Pós Graduação em Educação Física (PPGEF)/UFRN

\section{MAYARA MACIEL BATISTA}

Professora Mestre em Educação Física pelo Programa de Pós-graduação em Educação Física, da Universidade Federal do Paraná (PGEDF/UFPR), integrante do Grupo de Pesquisa em Mecânica e Energética do Movimento Humano - MEMH vinculado ao Departamento de Educação Física DEDUF/G, da Universidade Estadual do Centro-Oeste, campus CEDETEG - UNICENTRO/C. Possui experiência com Fisiologia do Exercício, Biomecânica do Esporte, Psicologia do Esporte e Treinamento Desportivo aplicado, principalmente, ao FUTSAL.

\section{NATHALY FREITAS DE SOUZA}

Graduada em fisioterapia pela Universidade Estadual do Norte do Paraná (2013). Pós Graduada em Dermato Funcional e Saúde da Mulher pela Universidade do Sagrado Coração (2015). Mestrado em andamento com previsão de conclusão em 06/08/2020 no programa de Ciências da Motricidade pela Faculdade de Ciências da Universidade Estadual Paulista (UNESP - Bauru).

\section{PATRICIA MOZART MOURA}

Possui graduação em Educação Física pela Universidade de Fortaleza (2003), especialista em Educação Física Escolar pela Faculdades Nordeste (2009) e mestre em Educação Física Escolar pela Universidade Federal do Rio Grande do Norte (UFRN)

\section{PAULA CAROLINA SILVA SANTOS}

Prof. formada em Licenciatura em Educação Física na Universidade do Estado do Pará - UEPA e em Bacharel em Educação Física na UNIASSELVI. Integrante do grupo de pesquisa Saude infanto-juvenil e educaçao fisica adaptada - SIJAVA. Tem experiência em Educação Física Adaptada/inclusiva e em atendimento personalizado.

\section{PAULO GOMES DE SOUSA-FILHO}

Pós-doutorado pela Universidade de Paris - René Descartes. Professor associado do curso de Psicologia e da Secretaria de Educação a Distância da Universidade Federal do Rio Grande. Graduação em psicologia com formação clínica em Análise do comportamento, terapia cognitiva/comportamental, e Terapias de Terceira geração (ACT, DBT, FAP e RFT). Doutor em informática na educação na UFRGS. Especialização em psicometria (avaliação e medidas em psicologia) e em psicologia do desenvolvimento (ambas na UnB), em Educação a Distância (SENAC- 
RS) e em mídias na educação (UFRGS). Coordena atualmente o CePsiCo - Centro de Psicologia Contextual. Coordena a especialização em Mídias na Educação da SEAD/FURG.

\section{PAULO HENRIQUE PAULI}

Professor Mestre em Educação Física pelo Programa de Pós-graduação em Educação Física, da Universidade Federal do Paraná (PGEDF/UFPR), integrante do Grupo de Pesquisa em Mecânica e Energética do Movimento Humano - MEMH vinculado ao Departamento de Educação Física DEDUF/G, da Universidade Estadual do Centro-Oeste, campus CEDETEG - UNICENTRO/C. Possui experiência com Fisiologia do Exercício, Biomecânica do Esporte e Treinamento Desportivo aplicado, principalmente, ao FUTSAL. Ex-atleta e, atualmente, preparador físico do Clube Atlético Desportivo (CAD) de Guarapuava/PR.

\section{PEDRO VÍTOR NASCIMENTO DE PAIVA}

Graduado em Educação Física pela Universidade do Estado do Pará (UEPA). Monitor acadêmico da disciplina fundamentos e métodos do esporte. Bolsista no programa de educação pelo trabalho em saúde (PET-saúde). Monitor no Laboratório de Atividade Física Adaptada (LAFAD). Integrante do grupo de pesquisa Saúde Infanto Juvenil e Educação Física Adaptada (SIJAVA).

\section{RAFAEL VIEIRA DE ARAÚJO}

Professor de Educação Física (UFG) e Pedagogo. Mestre em Educação. Especialista em Educação Física Escolar (UFG), Psicopedagogia (UEG) e EJA (UNB).

\section{RENATA DE OLIVEIRA CARVALHO}

Possui graduação em Educação Física pela Universidade Luterana do Brasil (2012), especialização em Mídias na Educação pela Universidade Federal de Rio Grande (2016) e mestrado em Ciências do Movimento Humano pela Universidade Federal do Rio Grande do Sul (2018). É professora de educação física do Instituto Federal de Mato Grosso no câmpus Sorriso. Também é cantora, compositora, membro do movimento negro NUMDI e da Casa da Cultura Hip-Hop de Esteio-RS. Suas áreas de atuação são educação física, escola, relações raciais, gênero e justiça social.

\section{RILDO VIEIRA DE ARAÚJO}

Possui Graduação em Agrimensura pelo Centro Federal de Ensino Tecnológico de Goiás (2003), Graduação em Matemática (2007), Especialista em Educação Matemática, Mestre em Ambiente e Desenvolvimento pelo Centro Universitário Univates (2014),Doutor em Ciências Ambientais e Sustentabilidade Agropecuária pela UCDB de Campo Grande-MS. Atualmente é professor de Agrimensura do Instituto Federal de Educação, Ciência e Tecnologia de Mato Grosso -Campus Barra do Garças

\section{ROMILDO DE ALBUQUERQUE NOGUEIRA}

Professor titular da Universidade Federal Rural de Pernambuco (UFRPE). Doutor em Ciências pela Universidade de São Paulo e pós -doutor em sistemas complexos pela Florida Atlantic University (FAU-USA). Ministra aulas em cursos de graduação e pós-graduação na UFRPE.

\section{SAMUEL PANATO}

Professor de Educação Física formado pela Universidade Estadual do Centro-Oeste, campus CEDETEG - UNICENTRO/C, integrante do Grupo de Pesquisa em Mecânica e Energética do Movimento Humano - MEMH, do Departamento de Educação Física - DEDUF/G. Possui experiência com Fisiologia do Exercício, Biomecânica do Esporte e Treinamento Desportivo aplicado, principalmente, ao FUTSAL. 


\section{SIMONE DE LA ROCQUE}

Graduada em Educação Física. Docente da Universidade do Estado do Pará. Coordenadora do Laboratório de Atividade Física Adaptada. Mestre em motricidade Humana. Doutora em Doenças Tropicais.

\section{SOLANGE RODOVALHO LIMA}

Doutorado em Educação Especial pela Universidade Federal de São Carlos (2009), Mestrado em Educação pela Universidade Federal de Uberlândia (1998), Graduação em Educação Física (1985) e em Pedagogia (1989) pela Universidade Federal de Uberlândia. Professora Associada, nível II, da Universidade Federal de Uberlândia, na Faculdade de Educação Física e Fisioterapia. Coordenadora do Programa de Extensão Atividades Físicas, Esportivas e de Lazer para Pessoas com Deficiência (PAPD/UFU). Coordenadora colaboradora do Programa Institucional de Bolsas de Iniciação à Docência (PIBID). Atua na área da Educação Física, com ênfase em Educação Física Adaptada e Educação Especial. Desenvolve e orienta pesquisas sobre: Educação Física Adaptada, inclusão escolar, educação física escolar e formação de professores. Membro do comitê científico do grupo de trabalho inclusão e diferenças do Colégio Brasileiro de Ciências do Esporte (CBCE).

\section{TATIANA ROBLES SANTIAGO}

Arte Educadora pela Unesp - Bauru. Artista. Fundadora e Professora da escola Casa do Circo. Atua na cidade de Bauru como Professora Circense na Viver Escola Waldorf. Promove capacitações e cursos on line sobre o ensino das atividades circenses na escola.

\section{TATIANE MEIRE MARTINS}

Formada em Licenciatura Plena em Educação Física pela Universidade Norte do Paraná em 2005. Especialista em Educação Física Escolar - FALBE (2007/08). Pós Graduanda em Arte na Educação: Dança, Música e Teatro (2019/20). Idealizadora do Projeto CIA Movimentação na Escola Padre Josimo Tavares. Professora efetiva, de carreira, na rede pública municipal de Palmas Tocantins desde 2010 como Professora da Dança. Professora do curso de Educação Física da Faculdade de Palmas - FAPAL desde 2012. Associada ao CBCE-TO, vinculada ao GTT-Escola.

\section{TERESA CRISTINA BARBO SIQUEIRA}

Professora da Pontifícia Universidade Católica de Goiás. Mestre em Filosofia, doutora em Educação. 
www.poisson.com.br contato@poisson.com.br

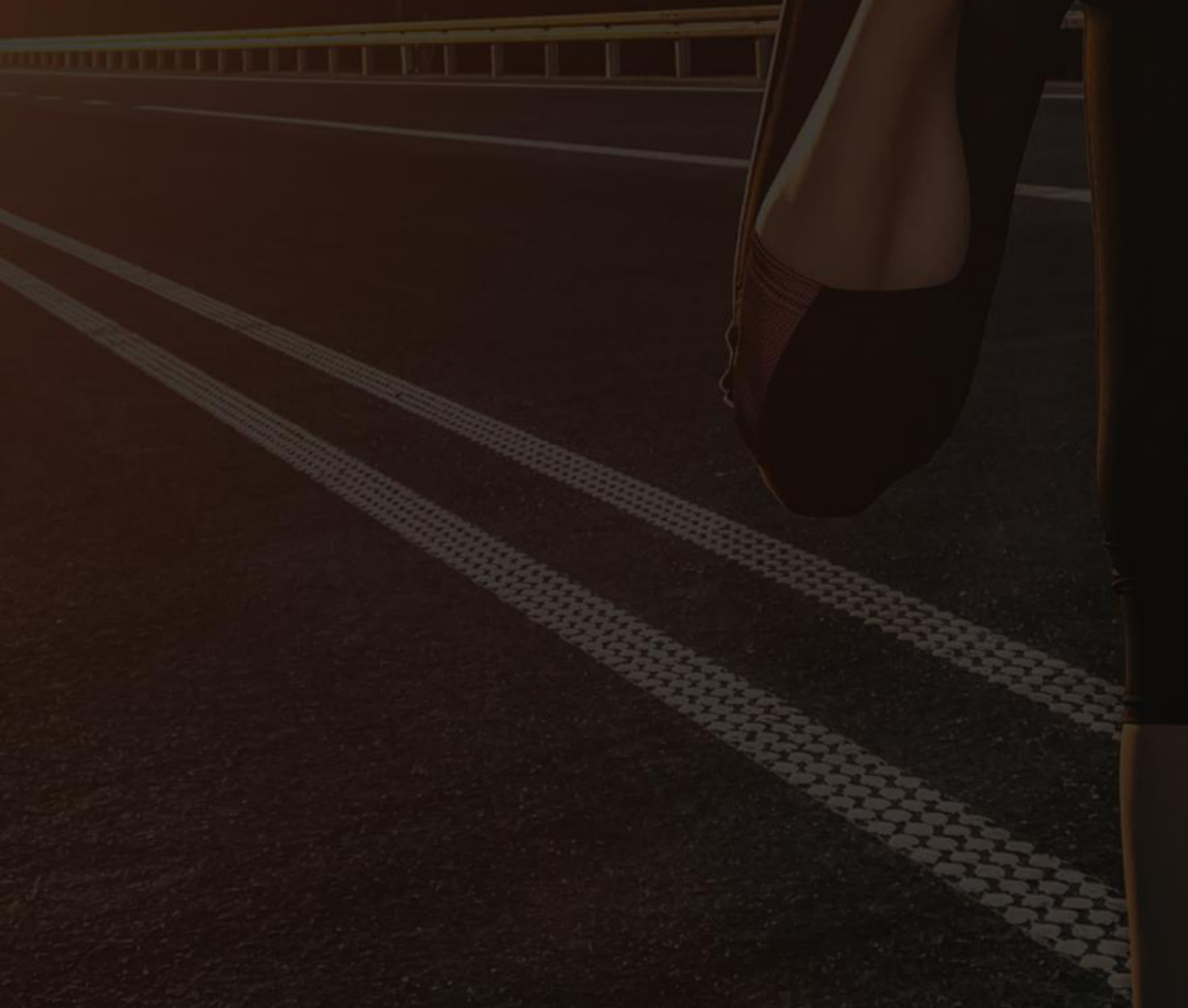

r

